\title{
Methods for Estimating Monthly and Annual Streamflow Statistics at Ungaged Sites in Utah
}

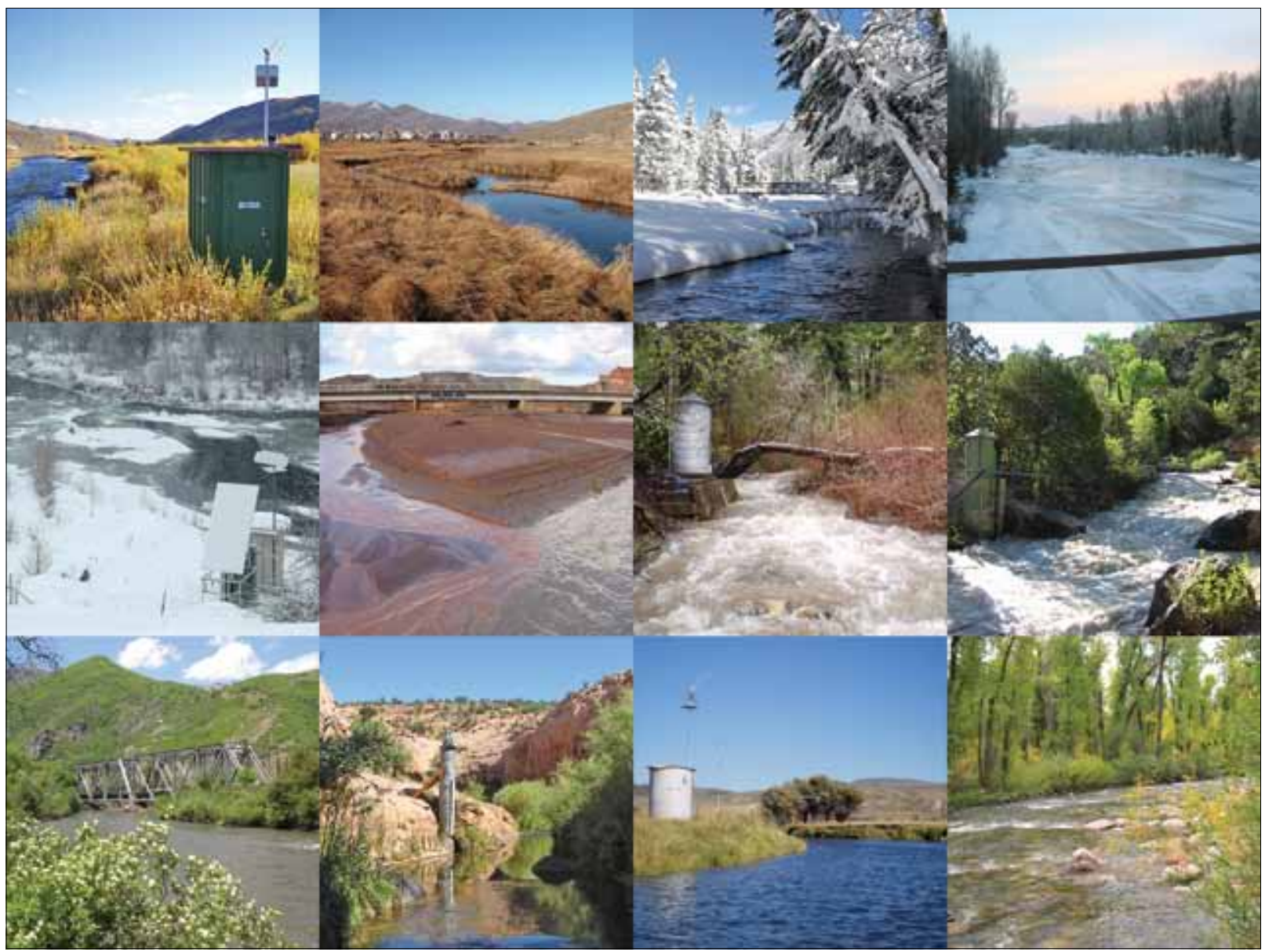

Prepared in cooperation with the

UTAH DEPARTMENT OF NATURAL RESOURCES, DIVISIONS OF WATER RIGHTS and WATER RESOURCES, and the UTAH DEPARTMENT OF TRANSPORTATION

Scientific Investigations Report 2008-5230 Version 2.0, April 2, 2011 
Cover: Photographic montage of U.S. Geological Survey streamflow gaging stations in Utah and Wyoming. All photographs are by U.S. Geological Survey personnel. 


\title{
Methods for Estimating Monthly and Annual Streamflow Statistics at Ungaged Sites in Utah
}

\author{
By Christopher D. Wilkowske, Terry A. Kenney, and Shane J. Wright
}

Prepared in cooperation with the

UTAH DEPARTMENT OF NATURAL RESOURCES, DIVISIONS OF WATER RIGHTS and

WATER RESOURCES, and the UTAH DEPARTMENT OF TRANSPORTATION

Scientific Investigations Report 2008-5230

Version 2.0, April 2, 2011

U.S. Department of the Interior

U.S. Geological Survey 


\title{
U.S. Department of the Interior \\ KEN SALAZAR, Secretary
}

\author{
U.S. Geological Survey \\ Marcia K. McNutt, Director
}

\section{U.S. Geological Survey, Reston, Virginia: 2008 \\ Version 2.0, April 2, 2011}

\author{
For additional information write to: \\ U.S. Geological Survey \\ Director, Utah Water Science Center \\ 2329 West Orton Circle \\ Salt Lake City, UT 84119-2047 \\ Email: GS-W-UTpublic-info@usgs.gov \\ URL: http://ut.water.usgs.gov/
}

\author{
For more information on the USGS - the Federal source for science about the Earth, its natural and living resources, \\ natural hazards, and the environment: \\ World Wide Web: http://www.usgs.gov \\ Telephone: 1-888-ASK-USGS \\ Any use of trade, product, or firm names is for descriptive purposes only and does not imply endorsement by the \\ U.S. Government. \\ Although this report is in the public domain, permission must be secured from the individual copyright owners to \\ reproduce any copyrighted materials contained within this report. \\ Suggested reference: \\ Wilkowske, C.D., Kenney, T.A., and Wright, S.J., 2008, Methods for estimating monthly and annual streamflow \\ statistics at ungaged sites in Utah: U.S. Geological Survey Scientific Investigations Report 2008-5230 , 63 p. Available \\ at http://pubs.usgs.gov/sir/2008/5230
}




\section{Contents}

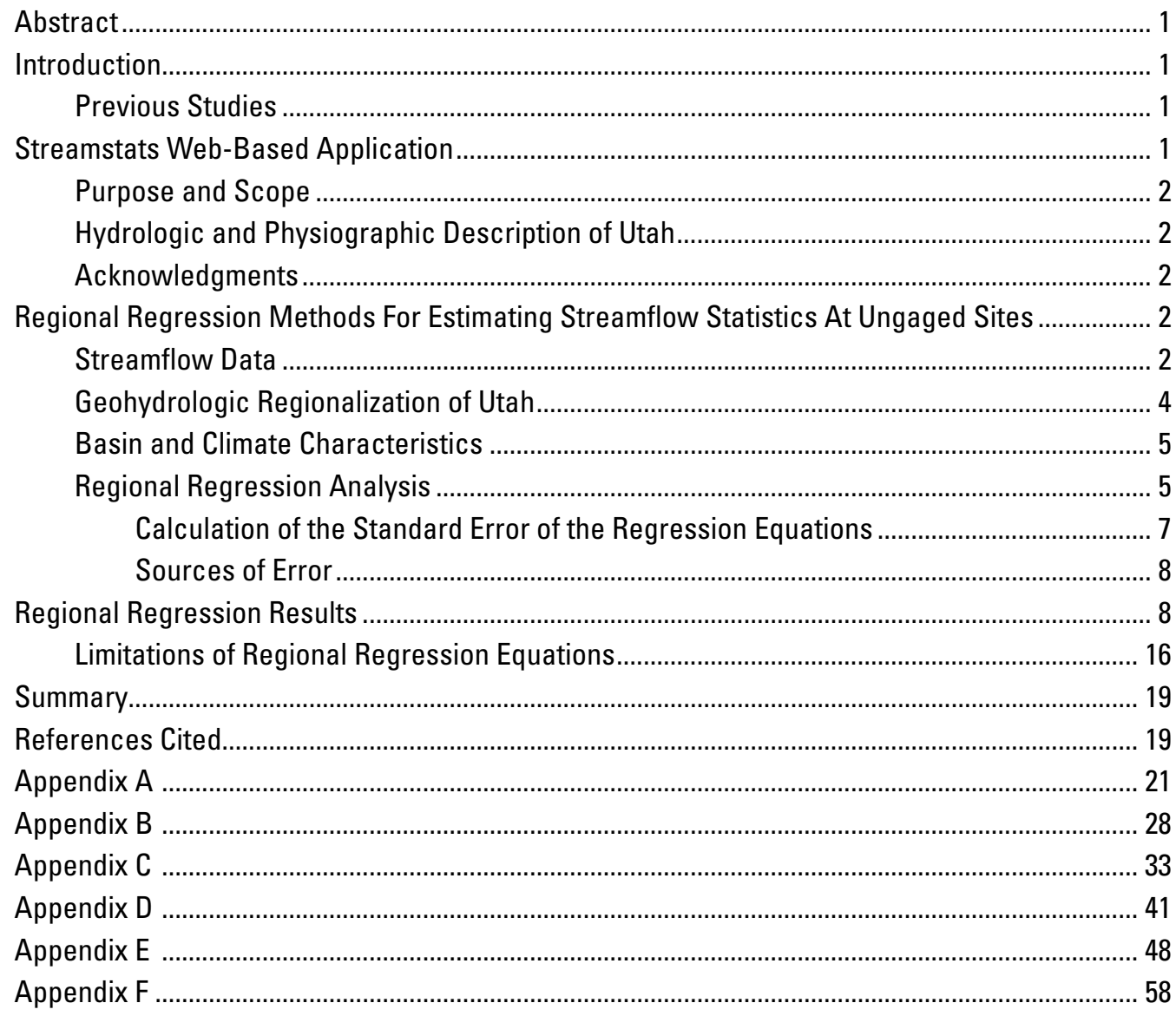

\section{Figures}

1 Map showing streamflow-gaging stations in Utah and bordering states used in the regional regression analysis ............................................................................... 3

2 Map showing geohydrologic regions of Utah used in the regional regression

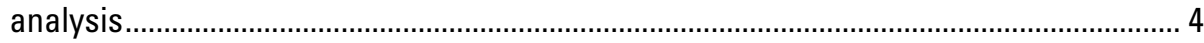

3 Graph showing residuals for the July exceedance equations for region 4 in Utah ...... 16

4 Graph showing residuals for the July exceedance equations for region 6 in Utah ...... 17 


\section{Tables}

1 Basin physiographic and climatic characteristics computed for Utah

2 Data sources used to compute basin physiographic and climatic characteristics in Utah

3 Regression equations and their associated uncertainty for estimating monthly 80-, 50-, and 20-percent exceedance streamflows for natural streams in region 1 in Utah.

4 Regression equations and their associated uncertainty for estimating monthly 80-, 50-, and 20-percent exceedance streamflows for natural streams in region 2 in Utah.

5 Regression equations and their associated uncertainty for estimating monthly 80-, 50-, and 20-percent exceedance streamflows for natural streams in region 4 in Utah.

6 Regression equations and their associated uncertainty for estimating monthly 80-, 50-, and 20-percent exceedance streamflows for natural streams in region 6 in Utah.

7 Regression equations and their associated uncertainty for estimating monthly 80-, 50-, and 20-percent exceedance streamflows for natural streams in region 7 in Utah.

8 Regression equations and their associated uncertainty for estimating monthly 80-, 50-, and 20-percent exceedance streamflows for natural streams in combined region 3 and region 5 in Utah.

9 Root mean square error percent associated with the monthly exceedance streamflow and annual mean streamflow regression equations for all regions, Utah

10 Basin physiographic and climatic characteristics used in the monthly exceedance and annual mean regression equations for Utah

11 Minimum, median, and maximum values of basin characteristics used in the regional regression analysis for Utah

\section{Appendices}

A Monthly and annual streamflow statistics for streamflow-gaging stations in region 1 in Utah and bordering states used in the regional regression analysis

B Monthly and annual streamflow statistics for streamflow-gaging stations in region 2 in Utah used in the regional regression analysis

C Monthly and annual streamflow statistics for streamflow-gaging stations in region 4 in Utah used in the regional regression analysis

D Monthly and annual streamflow statistics for streamflow-gaging stations in region 3 and region 5 in Utah and bordering states used in the regional regression analysis

E Monthly and annual streamflow statistics for streamflow-gaging stations in region 6 in Utah and bordering states used in the regional regression analysis .......

F Monthly and annual streamflow statistics for streamflow-gaging stations in region 7 in Utah and bordering states used in the regional regression analysis .... 


\section{Conversion Factors and Datums}

\begin{tabular}{lcl}
\hline \multicolumn{1}{c}{ Multiply } & By & \multicolumn{1}{c}{ To obtain } \\
\hline & Length & \\
\hline inch (in.) & 2.54 & centimeter $(\mathrm{cm})$ \\
inch (in.) & 25.4 & millimeter $(\mathrm{mm})$ \\
foot (ft) & 0.3048 & meter $(\mathrm{m})$ \\
mile (mi) & 1.609 & kilometer $(\mathrm{km})$ \\
\hline & Area & \\
\hline acre & 0.004047 & square kilometer $\left(\mathrm{km}^{2}\right)$ \\
\hline & Flow rate & \\
\hline cubic foot per second $\left(\mathrm{ft}^{3} / \mathrm{s}\right)$ & 0.02832 & cubic meter per second $\left(\mathrm{m}^{3} / \mathrm{s}\right)$ \\
\hline
\end{tabular}

Vertical coordinate information is referenced to the North American Vertical Datum of 1988 (NAVD 88).

Horizontal coordinate information is referenced to the North American Datum of 1983 (NAD 83). 


\section{Abbreviations and Acronyms Used in the Text}

(Clarification or additional information given in parentheses)

$\begin{array}{ll}\text { ADAPS } & \text { Automated Data Processing System } \\ \text { DVSTAT } & \text { daily values statistical program } \\ \text { GIS } & \text { geographic information system } \\ \text { GLS } & \text { generalized least squares } \\ \text { MSE } & \text { mean square error } \\ \text { NHD } & \text { National Hydrography Dataset } \\ \text { NWIS } & \text { National Water Information System (USGS) } \\ \text { OLS } & \text { ordinary least squares } \\ \text { RMSE } & \begin{array}{r}\text { root mean square error } \\ \text { StreamStats }\end{array} \\ & \text { A Web-based tool developed by the USGS that integrates published stream- } \\ & \text { flow-gaging station data and regional regression equations with a Web- } \\ \text { USGS } & \begin{array}{l}\text { U.S. Geological Survey } \\ \text { WLS }\end{array}\end{array}$




\title{
Methods for Estimating Monthly and Annual Streamflow Statistics at Ungaged Sites in Utah
}

\author{
By Christopher D. Wilkowske, Terry A. Kenney, and Shane J. Wright
}

\section{Abstract}

The monthly 80-, 50-, and 20-percent exceedance streamflows were calculated for 266 streamflow-gaging stations in Utah and the surrounding states. Using geographic information systems software, 24 physiographic and climatic basin characteristics were computed for each gaging station location. Using these data, regional regression equations were created to predict monthly $80-, 50$-, and 20-percent streamflow and annual mean streamflow at ungaged sites in Utah. The state of Utah was divided into seven distinct geohydrologic regions on the basis of a variety of physiographic, climatic, and hydrologic characteristics. Separate regression equations were developed for each region except region 3, which was combined with region 5 because of the small number of gaging stations in region 3 . Root mean square error percent for the equations ranged from 34 to 379 percent. The equations are more reliable for predicting high-streamflow statistics (20-percent exceedance) than for predicting the low-streamflow statistics (80-percent exceedance). In general, the mean annual streamflow equations had smaller errors than the monthly predicting equations. The developed equations documented in this report will be implemented in StreamStats, a USGS Webbased tool that allows users to obtain a variety of streamflow statistics and basin characteristics by selecting a location on a map interface.

\section{Introduction}

Monthly and annual streamflow information is required by fish and wildlife, water rights, and other land-use managers to assist in their decision-making processes. This type of information is available at sites where streamflow-gaging stations are located; however, there are numerous drainage basins in Utah with no existing streamflow information. Estimates are therefore needed for monthly and annual streamflow statistics in these areas. The generally accepted estimating method has been to use regionally based multiple-linear regression techniques to develop equations that predict certain streamflow statistics. The equations are typically valid only for a given geographic region and are based on existing streamflow information and measurable basin characteristics such as area and mean elevation. The U.S. Geological Survey (USGS), in cooperation with the Utah Department of Natural Resources, Divisions of Water Rights and Water Resources, and the Utah Department of Transportation, completed this study to develop new equations for estimating the monthly 80-, 50-, and 20-percent exceedance streamflows and the annual mean streamflow for natural drainage basins in Utah. The term "exceedance" refers to the streamflow value that is met or exceeded for a certain percentage of the time. For example, if the 80 -percent exceedance value for a given month is $25 \mathrm{ft}^{3} / \mathrm{s}$, that means that the streamflow at that location exceeds $25 \mathrm{ft}^{3} / \mathrm{s} 80$ percent of the time for that month.

\section{Previous Studies}

Whitaker (1971) evaluated the accuracy of estimates of mean annual streamflow by regionalizing data available up until the 1970 water year. Cruff (1975) estimated monthly and mean annual streamflows at sites in the Duchesne River Basin using a method termed the "monthly measurement method" described by Riggs (1969). Fields (1975) developed equations for estimating annual mean and peak streamflows in Utah using measured channel-geometry parameters. Fields and Adams (1976) developed regression equations to estimate mean annual streamflow in streams in northeastern Utah on the basis of drainage area and mean annual precipitation. They also described a technique for estimating monthly mean streamflow from the mean annual streamflow in the same area. Christensen and others (1985) presented methods for estimating mean annual streamflow for natural drainage basins in the Colorado River Basin using regional regression equations.

\section{Streamstats Web-Based Application}

StreamStats is a Web-based tool developed by the USGS that integrates published streamflow-gaging station data and regional regression equations with a Web-based geographic information system (GIS) (Ries and others, 2004). StreamStats allows a user to obtain a variety of streamflow statistics and basin characteristics by selecting a location on a map interface. 
The software then delineates the drainage basin upstream from that location, computes drainage basin characteristics, and applies the developed streamflow regression models. Published data can be obtained if the user selects the location of a USGS streamflow-gaging station. If the location of interest does not have a gaging station, StreamStats will apply published regression equations for that location and estimate the associated streamflow statistics. The methods used in computing the predictor variables used in the development of the regression equations is preserved in the StreamStats application. StreamStats can be accessed at http://water.usgs.gov/osw/ streamstats/. To use StreamStats with the equations described in this report, navigate within the above StreamStats website to the state application for Utah.

\section{Purpose and Scope}

This report documents the development of regional regression equations that can be used to estimate the 80-, 50-, and 20-percent exceedance streamflows and the annual mean streamflow for ungaged locations on unregulated streams in Utah. Limitations associated with the regional regression equations including uncertainty, presented as the root mean square error expressed as a percent, are discussed. Streamflow data used in the development of the regression equations are tabulated in this report. StreamStats, a Web-based tool that allows users to obtain streamflow statistics, drainage-basin characteristics, and other information for user-selected sites on streams, is also discussed.

\section{Hydrologic and Physiographic Description of Utah}

The study area for this report includes the entire state of Utah and areas of adjacent states that include overlapping hydrologic boundaries (fig. 1). The major drainage basins in Utah are the Green River Basin, the Colorado River Basin, the Virgin River Basin, the Sevier River Basin, and the Great Basin (Great Salt Lake) (fig. 1). Land-surface elevations range from 13,528 ft at Kings Peak in the Uinta Mountains of northeastern Utah, to about 2,000 ft near Beaver Dam Wash in southwestern Utah. Hydrologic conditions in Utah can vary greatly across the state because of the wide range in topography and geology, changing seasonal atmospheric conditions, and changes in climatic conditions from year to year. Mountain ranges and plateaus in many parts of Utah are characterized by steep slopes, sparse vegetation, and thin soils. Drainages in these areas typically receive most of their precipitation as snowfall and experience the highest streamflow during the spring snowmelt runoff from April to June. Much of the Colorado River Basin is characterized by large expanses of exposed bedrock and steep-walled canyons that can cause rapid runoff and flooding at any time of the year. The large valleys and basins in the western part of Utah have a fairly flat topography and are underlain with alluvial soils composed of clay, silt, sand, and gravel. The average annual precipitation in Utah ranges from about 5 in. in the Great Salt Lake Desert to about 60 in. on some of the state's highest mountains.

\section{Acknowledgments}

The authors would like to acknowledge the efforts of the dedicated hydrographers, past and present, from the USGS Utah Water Science Center and surrounding USGS Water Science Centers that have been responsible for the collection, computation, and analysis of streamflow data used in this report. The authors would also like to acknowledge the work of Scott Bartholoma from the USGS Office of Water Information and Charles Berenbrock of the USGS Office of Surface Water for helping to retrieve the streamflow statistics used in this report, and the work of Dave Lorentz of the USGS Minnesota Water Science Center and Ken Eng of the USGS Office of the Chief Scientist for Hydrology for providing statistical expertise for this report.

\section{Regional Regression Methods For Estimating Streamflow Statistics At Ungaged Sites}

\section{Streamflow Data}

For over 100 years, the USGS in Utah has been calculating and publishing daily mean discharge at streamflow-gaging stations. Daily mean discharge is calculated by measuring river stage, typically at 15-minute intervals, at a station. The stage values are converted to discharge using an updated stage-discharge relation called a "rating table." Daily mean discharge is calculated from the instantaneous discharge values. All of the daily and annual mean streamflow data were obtained from the USGS National Water Information System (NWIS) database. The daily values statistical program (DVSTAT) in the Automated Data Processing System (ADAPS) version 4.7 database was used to compute the monthly $80-, 50-$, and 20 -percent exceedance values. All exceedance values calculated for this report were based on data collected through water year 2006. Exceedance values from 266 streamflow-gaging stations were obtained to develop the regional regression equations in Utah (fig. 1). Daily mean streamflow has been computed for each of these stations for 10 years or more, and has not been significantly affected by regulation or diversions. Of the 266 gages, 50 were not used in the regression analysis after they were screened for statistical outliers in the streamflow and basin characteristics dataset. The monthly exceedance values and annual mean streamflow computed for each station are listed in appendices $\mathrm{A}-\mathrm{F}$. 


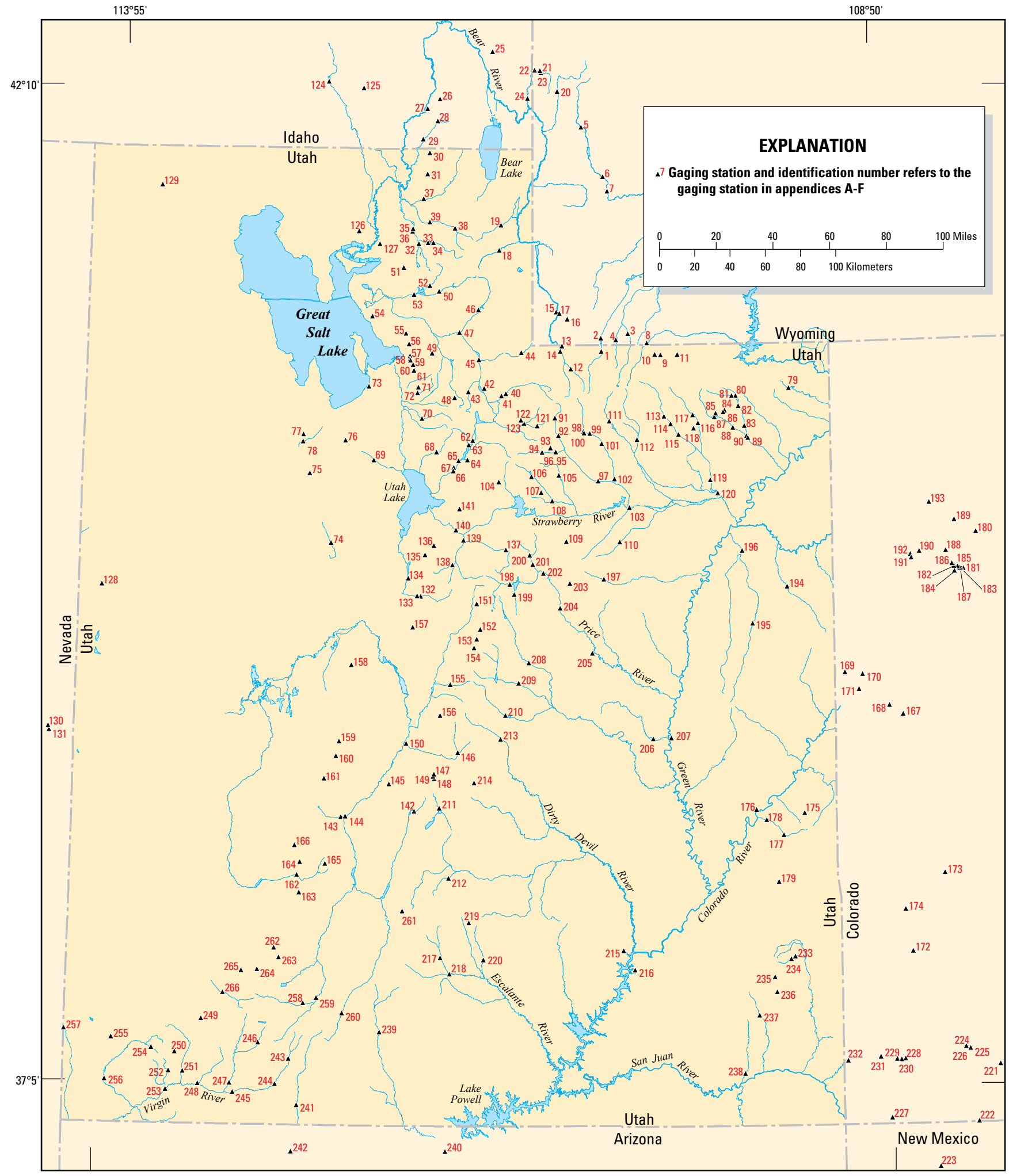

Figure 1. Streamflow-gaging stations in Utah and bordering states used in the regional regression analysis. 


\section{Geohydrologic Regionalization of Utah}

In an effort to compute regression equations on the basis of localized basin physiographic and climatic characteristics, seven distinct geohydrologic regions for Utah were defined (fig. 2). The regions were determined on the basis of the following factors: (1) statistically significant groupings of basin and climatic characteristics of streamflow-gaging stations using cluster analysis techniques; (2) statewide landscape features; (3) climatic regions defined by the National Oceanic and Atmospheric Administration (National Oceanic and Atmospheric Administration, 1994); (4) physiographic provinces defined by the Utah Geological Survey (Utah Geological Survey, 2007); (5) defined flood regions of the southwestern United Stated as defined by Thomas and others (1997); and (6) scientific judgment that is based on general hydrologic knowledge of the area. For a more detailed description of factors 3, 4, and 5, see Kenney and others (2007). The seven regions were divided along hydrologic boundaries except for a portion of the divisions between regions 3 and 5, 3 and 7, and 2 and 4 . These nonhydrologic divisions agreed with the general definition of the surrounding regions, taking into account the factors listed above. The locations of streamflow-gaging stations used for the definition of the regions are shown in figure 1 . Regions $1,2,4$, and 5 generally are related to the geographic areas of the Wasatch and Uinta Mountains, the two principal mountain ranges in Utah. The north slope of the Uinta Mountains and most of the upper Bear River Basin are contained in region 1. The northern and central parts of the Wasatch Mountains define regions 2 and 5, respectively. The south slope of the Uinta Mountains, including the Uinta Basin, make up region 4. Region 3 includes the western part of the state, most of which is contained within the arid Basin and Range physiographic province. Region 6, the largest defined, encompasses most of the Colorado Plateau. The Virgin River Basin is mostly contained in region 7 . There were only eight stations available

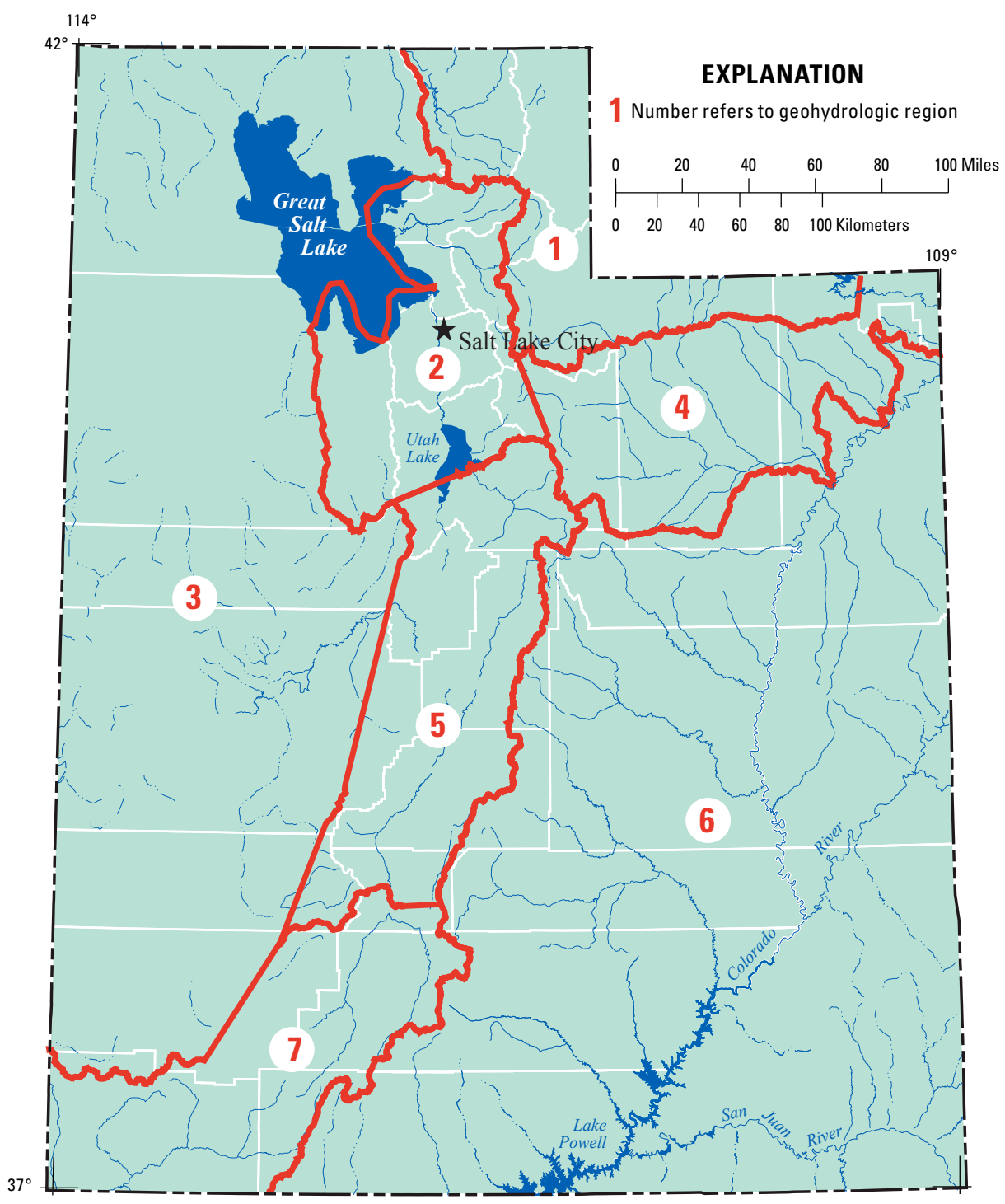

Figure 2. Geohydrologic regions of Utah used in the regional regression analysis. 
from region 3 that met the minimum 10-year period of record length criteria. Therefore, the data from regions 3 and 5 have been combined to create regression equations that cover both regions.

\section{Basin and Climate Characteristics}

Using a GIS, 21 physiographic characteristics and 3 climatic characteristics were computed for the drainage basin of each streamflow-gaging station. Each of these characteristics potentially has an influence on the streamflow statistics of interest in this report. Geospatial algorithms, developed using Arc Macro Language programs written for ArcGIS (Environmental Systems Research Institute, Inc., 1999), were used to compute basin characteristics. The values generated for each characteristic (table 1) are directly dependent on the algorithm, dataset, and spatial scale(s) used in their computation. The datasets used to compute basin characteristics are described in table 2 . Of the 24 computed characteristics, area, relief, mean elevation, mean basin slope, percentage of basin slope greater than 30 percent, percentage of area covered by forest, percentage of area covered by herbaceous upland, mean annual precipitation, and mean monthly precipitation were selected for more extensive statistical testing.

\section{Regional Regression Analysis}

The regional method of regression analysis, as presented in this report, regresses streamflow statistics against several basin characteristics that have been determined at streamflowgaging stations for the seven different geohydrologic regions of Utah. Equations to predict the 80-, 50-, and 20-percent

Table 1. Basin physiographic and climatic characteristics computed for Utah.

[Datasets: NED, National Elevation Dataset; NLCD, National Land Cover Dataset; PRISM. Parameter-Elevation Regressions on Independent Slopes Model; NOAA, National Oceanic and Atmospheric Administration]

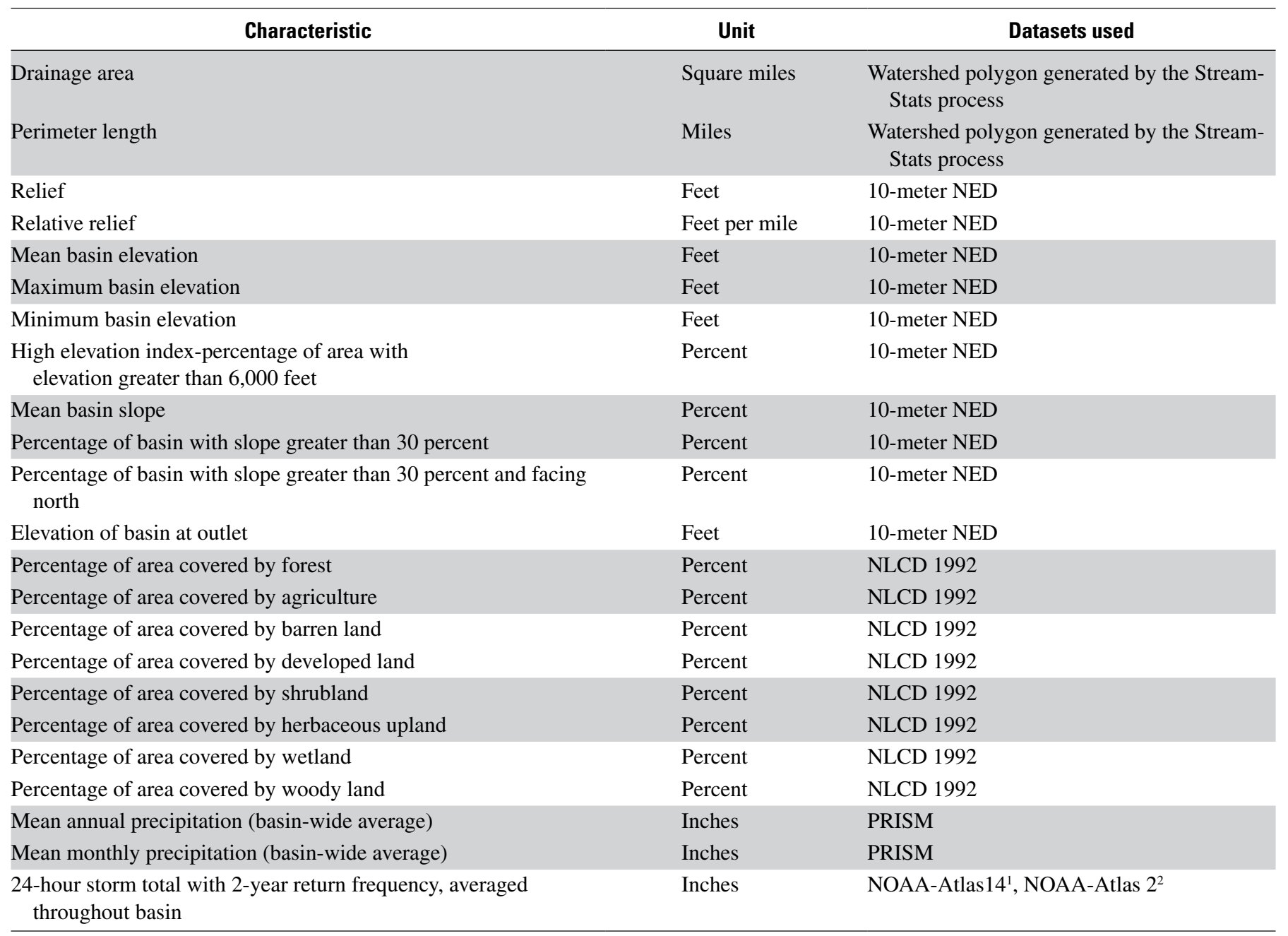

${ }^{1}$ Used for Utah, Nevada, Arizona, and New Mexico.

${ }^{2}$ Used for Idaho, Wyoming, and Colorado. 
exceedance streamflows and the annual mean streamflow were developed for all seven geohydrologic regions of Utah. Regions 3 and 5 use the same set of equations.

When developing regression equations for research purposes, it may be inappropriate to remove outliers from datasets (Helsel and Hirsch, 1992). However, for the purposes of this study, the authors decided to develop a tool for engineers and water managers that was not influenced by extreme basin characteristics or events. Therefore, streamflow data and basin characteristics were screened using boxplots to remove outliers from the data. Data were screened using boxplots to identify the 5th and 95th percentiles for the following basin characteristics: area, relief, mean elevation, mean basin slope, percentage of basin slope greater than 30 percent, percentage of area covered by forest, percentage of area covered by herbaceous upland, mean annual precipitation, and mean monthly precipitation. An "outlier score" was then developed by weighting the occurrence of basin characteristics that were below the 5th percentile or above the 95th. If a station exceeded an outlier score of 5 points, it was not used in the analysis. Because drainage basin area is the most influential characteristic in the regression equations, it was given the most weight in the outlier score ( 5 points). Therefore, if drainage area for a station fell below the 5th or above the 95th percentile for a given region, it was not used in the analysis. This was done in an effort to lessen the skew of the equations towards extreme events. Relief, mean elevation, mean annual precipitation, and mean monthly precipitation were given a slightly lower weight ( 2 points); and mean basin slope, percentage of basin slope greater than 30 percent, percentage of area covered by forest, and percentage of area covered by herbaceous upland were given the lowest weight (1 point). Most of the stations that were excluded were based on drainage basin size.

A similar approach to the one described above was used to screen for outliers in the streamflow exceedance data. If the streamflow value was below the 5th percentile or above the 95th percentile for two of the three calculated statistics (20-, $50-$, or 80-percent exceedance) for a given month and region, the station was not used in the analysis. The streamflow data were evaluated by region and by month. Therefore, a different number of streamflow-gaging stations was used for different months in a given region. A total of 216 stations throughout the study area were used to create the final equations.

All streamflow data were transformed to base-10 logarithms. Basin characteristic data were transformed to a base-10 logarithm if it enhanced symmetry of the data by decreasing the magnitude of skew in the data distribution. Transformations were also used if they appeared to improve the linearity of the equation. If no noticeable improvement in the linearity of the data was observed, the data were left untransformed. For basin characteristics defined as percentages, such as slope percent, a value of 0.001 percent was added prior to the base-10 logarithm transformation to prevent null values that occur as a result of taking the logarithm of zero.

An ordinary least squares (OLS) regression technique, applied by the statistical computer program S-PLUS 7.0 (Insightful Corporation, 2005), was used to develop the 80-, 50-, and 20-percent exceedance streamflow and annual mean streamflow equations for each region. The OLS regression technique was chosen over weighted least squares (WLS) and generalized least squares (GLS) regression. WLS gives weights to certain variables used in the regression analysis. For instance, streamflow statistics calculated from a gage with 75 years of record could be more heavily weighted than those from a gage with only 10 years of record. To apply WLS regression technique, a weighting scheme that accurately describes which observations should be given more weight in the analysis needed to be defined. Such a scheme was not easily defined for the monthly exceedance and annual mean streamflow data used in this analysis. Also, when determining the uncertainty associated with equations developed from WLS regression technique, the weighting approach needed

Table 2. Data sources used to compute basin physiographic and climatic characteristics in Utah.

[Datasets: NED, National Elevation Dataset; NLCD, National Land Cover Dataset; PRISM. Parameter-Elevation Regressions on Independent Slopes Model; NOAA, National Oceanic and Atmospheric Administration]

\begin{tabular}{ll}
\hline \multicolumn{1}{c}{ Dataset name } & \multicolumn{1}{c}{ Source description } \\
\hline 10-meter National Elevation Dataset (NED) & $\begin{array}{l}\text { U.S. Geological Survey, 1999 } \\
\text { (http://erg.usgs.gov/isb/pubs/factsheets/fs 14899.html) }\end{array}$ \\
National Land Cover Dataset (NLCD, 1992) & $\begin{array}{l}\text { Vogelmann and others, 1998 } \\
\text { (http://edcwww.cr.usgs.gov/programs/lccp/) }\end{array}$ \\
$\begin{array}{l}\text { Precipitation frequency atlas of the United States (National Oceanic } \\
\text { Bonnin and others, 2006 } \\
\text { (http://hdsc.nws.noaa.gov/hdsc/pfds/docs/NA14Voll.pdf) }\end{array}$ \\
$\begin{array}{l}\text { Precipitation frequency atlas of the United States (National Oceanic } \\
\text { and Atmospheric Administration Atlas 2) }\end{array}$ & $\begin{array}{l}\text { Miller and others, 1973 } \\
\text { (http://www.nws.noaa.gov/ohd/hdsc/noaaatlas2.htm) }\end{array}$ \\
$\begin{array}{l}\text { Parameter-elevation Regressions on Independent Slopes Model } \\
\text { (PRISM) climate mapping system, total precipitation (30-year } \\
\text { average, 1971-2000) }\end{array}$ & $\begin{array}{l}\text { Daly and others, 1994 } \\
\text { (http://prism.oregonstate.edu/products/) }\end{array}$ \\
\hline
\end{tabular}


to be considered and used in the uncertainty computation. Unfortunately, this information was not readily available from the computer program used. A disadvantage of not using WLS is that a time-sampling error that could be caused by a short period of record is not accounted for in the calculation. The GLS regression technique developed by Stedinger and Tasker (1985) and Tasker and Stedinger (1989) is designed to be used for peak-flow and low-flow analyses and does not lend itself to monthly exceedance or annual mean streamflow data analyses.

For some of the drier regions of Utah, zero-flow values for monthly exceedances were calculated, indicating that the stream is not perennial. These zero-flow values strongly skew the data in the negative direction and cannot be properly dealt with using OLS regression. A logistic regression could have been applied to determine the probability of flow reaching zero; however, it is beyond the scope of this report. Therefore, zero-flow values in the streamflow data were removed during the outlier screening process. Most of the zero-flow values occur in region 6. If the equations developed in this report are used on ephemeral or intermittent streams, the estimated flow will most likely be too high.

Prior to the regression analysis, a correlation matrix of all the basin characteristics was examined to avoid problems with multicollinearity. Initially, an exploratory stepwise regression approach was used to identify the basin and climatic characteristics that best predicted the 50-percent exceedance value for each month and region. Following this analysis, one, two, or three basin characteristics were tested together with the 80-, 50-, and 20-percent exceedance values as the response variables. To prevent the 80 -percent exceedance equation from predicting a higher streamflow than the 50- or 20-percent exceedance equations, the set of predictor variables was kept the same for each exceedance equation within a given month. The combination of variables with the highest F-statistic and lowest residual standard error was chosen, and the final regression calculation was performed for each exceedance statistic. The F-statistic is a test of the analysis of variance that takes into account the loss of degrees of freedom that would result when an additional explanatory variable is added. All equations were found to be statistically significant to the 0.01 level of the calculated $\mathrm{p}$-value. The $\mathrm{p}$-value is a measure of the level of significance of the equation that is based on the probability that the variables in the given equation truly explain the predicted value. The annual mean streamflow equations were created using the same process.

The developed equations all have the linear form:

$$
Q=\beta_{0}+\beta_{1} x_{1}+\beta_{2} x_{2}+\ldots+\beta_{n} x_{n}
$$

Where:

$Q \quad$ is the response variable in cubic feet per second,

$\beta_{0} \quad$ is the intercept,

$\beta_{1} \quad$ is the slope coefficient of the first explanatory variable,

$\mathrm{X}_{1}$ is the first explanatory variable,

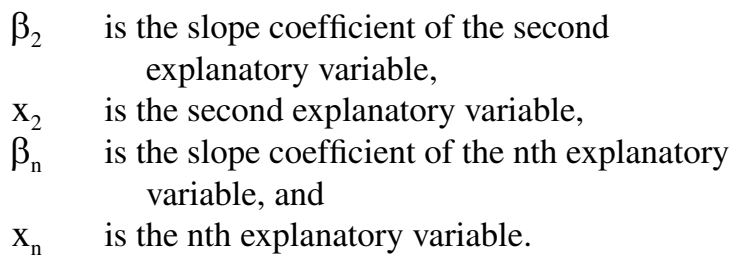

The base-10 logarithm form of the equations takes the following form:

$$
\log Q=\log \beta_{0}+\beta_{1} \log x_{1}+\beta_{2} \log x_{2}+\ldots+\beta_{n} \log x_{n}
$$

The antilogarithms of equations where all of the variables have been base-10 logarithm transformed take the following form:

$$
Q=\beta_{0} x_{1}^{\beta_{1}} x_{2}^{\beta_{2}} \ldots x_{\mathrm{n}}^{\beta_{\mathrm{n}}}
$$

For equations that use both base-10 logarithm transformed and nontransformed variables, the equations are in the following form:

$$
Q=\beta_{0} x_{1}^{\beta_{1}} 10^{\beta_{2} x_{2}+\ldots+\beta_{\mathrm{n}} x_{\mathrm{n}}}
$$

\section{Calculation of the Standard Error of the Regression Equations}

For each regression equation, the mean square error (MSE) has been calculated. The MSE was calculated using the squared prediction residual that is computed from the "hat matrix," which is a matrix of computed equation coefficients with the $i$ th observation left out. The "hat matrix" is defined as:

$$
\mathbf{H}=\mathbf{X}\left(\mathbf{X}^{\mathrm{T}} \mathbf{X}\right)^{-1} \mathbf{X}^{\mathrm{T}}
$$

Where:

$$
\begin{gathered}
\mathbf{H} \text { is the hat matrix } \\
\mathbf{X} \text { is a matrix of the equation coefficients, and } \\
\mathbf{X}^{\mathrm{T}} \text { is the transpose matrix of equation } \\
\text { coefficients. }
\end{gathered}
$$

The prediction residual is calculated from the $i$ th diagonal term of $\mathbf{H}$ and is denoted as $\mathbf{h}_{\mathrm{i}}$ and calculated as:

$$
e(i)=\frac{e_{\mathrm{i}}}{\left(1-\mathbf{h}_{\mathrm{i}}\right)}
$$

Where:

$$
\begin{gathered}
e(i) \quad \text { is the prediction residual for the } i \text { th } \\
\text { observation, } \\
e_{i} \quad \text { is the } i \text { th observed value, and } \\
\mathbf{h}_{\mathrm{i}} \quad \text { is the } i \text { th diagonal observation of the hat } \\
\text { matrix. }
\end{gathered}
$$


The MSE is then calculated as the mean of the squared prediction residuals. To describe the error associated with the regression equations in terms of percent, the MSE was converted to root mean square error (RMSE), expressed as a percentage using the following equation (Aitchison and Brown (1957), modified for use of base-10 logarithms:

$$
R M S E_{\mathrm{p}}=100\left[e^{(\ln 10)^{2} M S E}-1\right]^{0.5}
$$

Where:

$$
\begin{aligned}
R M S E_{\mathrm{p}} & \text { is the root mean square error in percent, } \\
e & \text { is the base of the natural logarithm }
\end{aligned}
$$

and

$$
M S E \quad \text { is the mean square error calculated from the }
$$$$
\text { prediction residual }
$$

\section{Sources of Error}

The RMSE in percent represents the total error for the regional regression equations in this report. Total error is comprised of time-sampling error and model error variance. Time-sampling error consists of errors in the streamflow data and is a function of sample size, in this case, the length of data records. For instance, if a station operated for 10 years during a dry cycle, it may not be a good predictor of future streamflow in the area. The OLS regression technique used in this analysis does not account for time-sampling error. Model error variance represents the error in the relation between a streamflow statistic and a set of basin characteristics used to predict that statistic. One of the basic assumptions of multiple linear regression is that the input data are truly linear, or in this study, log-linear. A portion of the model error may result because some of the data used in the regression may not be truly loglinear. No attempt was made to distinguish between model variance error and time-sampling error for this study.

\section{Regional Regression Results}

Regression equations were developed for region 1 (table 3), region 2 (table 4), region 4 (table 5), region 6 (table 6), and region 7 (table 7) for each month to estimate the monthly 80-, 50-, and 20-percent exceedance streamflows. Regions 3 and 5 were combined for this study and use the same set of equations (table 8). Regression equations also were developed for each region to estimate annual mean discharge (tables 3-8).

The RMSE in percent has been calculated for each regression equation (tables 3-9). The root mean square error ranges from 34 percent for the May 20-percent exceedance equation in region 4 to 379 percent for the July 80-percent exceedance equation in region 6 . For all regions, the equations are better at predicting high streamflow values (20-percent exceedance) than low-flow values (80-percent exceedance). This finding is consistent with other reports (Hortness and Berenbrock, 2001) and is logical because low flows are strongly influenced by local geology that is difficult to quantify (Riggs, 1972). In general, the annual mean equations have a lower error than most of the monthly equations. Although region 6 had the greatest number of stations available to develop the equations (42 to 50 stations for the monthly analysis), in general, it also had the greatest amount of error. Region 6 incorporates the Colorado Plateau in Utah and is the largest defined region for this report. This region consists of high plateaus and mountain ranges that contribute relatively little flow to most streams, with large expanses of arid lowlands, often characterized by exposed bedrock. All of the regression equations in this report are based on the observation that areas with a larger contributing drainage basin generally have higher streamflows. In region 6 , most of the drainage basins fit these criteria; however, because of the arid nature of the region, there are many large drainage basins that have very little or zero flow. The belief is that these opposing relations are part of the cause of the large error in region 6. Land-cover basin characteristics such as percentage of area covered by forest and percentage of area covered by herbaceous upland, were examined for region 6; however, neither of these factors appeared to be a good predictor of streamflow. The past efforts of Christensen and others (1985) created subregions in the mountainous areas of the Colorado Plateau to differentiate the different drainage types. This was not attempted for this report.

Figure 3 is a residual plot for the region 4 July exceedance equations. The 20-percent exceedance equation for July in region 4 had the lowest error (34 percent). For comparison, a residual plot for the July equations in region 6 is shown in figure 4. The July 80-percent exceedance equation had an error of 346 percent. For valid unbiased regression equations, the residuals should have a normal distribution. Problems with nonlinearity are shown by points forming a curve. Problems with non-normal distributions are shown when points are not equally above or below the zero-axis line. Residual plots were examined for each regression equation. In general, the residual plots appeared to be slightly nonhomoscedastic, with a slight trend toward smaller variance with smaller discharge. Logarithm base-10 transformations of the data did not appear to affect the distribution of the residuals dramatically.

On average, the error from the monthly equations in combined regions 3 and 5 was the lowest. However, it should be noted that most of the stations used for this analysis are located in region 5. If the equations are used to predict streamflow in region 3 , the error is likely greater than that stated here.

The most widely used characteristics for the final regional regression equations were drainage area (100 percent of the equations), mean annual precipitation (40 percent of the equations), mean monthly precipitation (22 percent of the equations), and mean basin elevation (19 percent of the equations) (table 10). In general, most of the regression equations use drainage area and either mean annual basin precipitation or mean basin elevation, which are closely related. These predictors make hydrologic sense because most streamflow 
Table 3. Regression equations and their associated uncertainty for estimating monthly 80-, 50-, and 20-percent exceedance streamflows for natural streams in region 1 in Utah.

[Regression variables: $\mathrm{Q}_{\mathrm{P} 80}$, daily mean discharge exceeded 80 percent of the time during the specified month, in cubic feet per second; $\mathrm{Q}_{\mathrm{P} 50}$, daily mean discharge exceeded 50 percent of the time during the specified month, in cubic feet per second; $\mathrm{Q}_{\mathrm{p} 20}$, daily mean discharge exceeded 20 percent of the time during the specified month, in cubic feet per second; DRNAREA, drainage area, in square miles; BSLDEM10M, average basin slope, in percent; PRECIP, mean annual precipitation, in inches; SLOP30, basin slope that exceeds 30 percent, in percent; PRC12, mean December precipitation, in inches; PRC2, mean February precipitation, in inches; ELEV, mean basin elevation, in feet; PRC6, mean June precipitation, in inches; FOREST, area covered by forest, in percent; $\mathrm{Q}_{\mathrm{ANNMEAN}}$, annual mean discharge, in cubic feet per second]

\begin{tabular}{|c|c|c|}
\hline $\begin{array}{l}\text { Regression equation for given monthly exceedance } \\
(80,50 \text {, and } 20 \text { percent exceedance })\end{array}$ & $\begin{array}{l}\text { Root mean } \\
\text { square error } \\
\text { (percent) }\end{array}$ & $\begin{array}{l}\text { Number of streamflow- } \\
\text { gaging stations used in } \\
\text { regression analysis }\end{array}$ \\
\hline \multicolumn{3}{|l|}{$\begin{array}{lll}2 & \text { October } \\
\end{array}$} \\
\hline $\mathrm{Q}_{\mathrm{P} 80}=5.5463 \mathrm{E}-03$ DRNAREA $^{0.3643}(\mathrm{BSLDEM} \mathrm{DM}+0.001)^{1.0454} 10^{0.0386 \text { PRECIP }}$ & 105 & \multirow{3}{*}{39} \\
\hline $\mathrm{Q}_{\mathrm{P} 50}=1.8088 \mathrm{E}-02 \mathrm{DRNAREA}^{0.3914}(\mathrm{BSLDEM} 10 \mathrm{M}+0.001)^{0.9229} 10^{0.0309 \text { PRECIP }}$ & 96.9 & \\
\hline $\mathrm{Q}_{\mathrm{P} 20}=8.6139 \mathrm{E}-02$ DRNAREA $^{0.4283}(\mathrm{BSLDEM} \mathrm{B} \mathrm{M}+0.001)^{0.6905} 10^{0.0229 \text { PRECIP }}$ & 83.2 & \\
\hline \multicolumn{3}{|l|}{$\begin{array}{ll}20 & \text { November }\end{array}$} \\
\hline $\mathrm{Q}_{\mathrm{P} 80}=7.2879 \mathrm{E}-02 \mathrm{DRNAREA}^{0.4551} 10^{0.0368 \text { PRECIP + 0.0068 (SLOP30+0.001) }}$ & 103 & \multirow{3}{*}{39} \\
\hline $\mathrm{Q}_{\mathrm{P} 50}=2.5038 \mathrm{E}-01$ DRNAREA ${ }^{0.4555} 10^{0.0252 \mathrm{PRECIP}+0.0064(\mathrm{SLOP} 30+0.001)}$ & 93.6 & \\
\hline $\mathrm{Q}_{\mathrm{P} 20}=5.8063 \mathrm{E}-01 \mathrm{DRNAREA}^{0.4765} 10^{0.0165 \text { PRECIP + 0.0064(SLOP } 30+0.001)}$ & 85.9 & \\
\hline \multicolumn{3}{|l|}{ CW } \\
\hline $\mathrm{Q}_{\mathrm{P} 80}=1.8724 \mathrm{E}-01$ DRNAREA $^{0.3929} 10^{0.3916 \mathrm{PRC} 12}$ & 84.7 & \multirow{3}{*}{39} \\
\hline $\mathrm{Q}_{\mathrm{P} 50}=3.6568 \mathrm{E}-01 \mathrm{DRNAREA}^{0.4040} 10^{0.3270 \mathrm{PRC} 12}$ & 81.2 & \\
\hline $\mathrm{Q}_{\mathrm{P} 20}=5.6925 \mathrm{E}-01 \mathrm{DRNAREA}^{0.4354} 10^{0.2794 \mathrm{PRC} 12}$ & 78.8 & \\
\hline \multicolumn{3}{|l|}{ 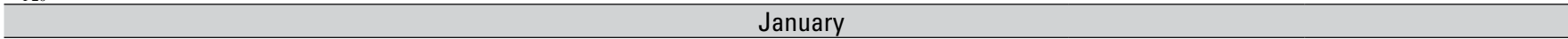 } \\
\hline $\mathrm{Q}_{\mathrm{P} 80}=1.3231 \mathrm{E}-02$ DRNAREA $^{0.4043}\left(\right.$ BSLDEM10M+0.001) $^{1.5926}$ & 83.1 & \multirow{3}{*}{37} \\
\hline $\mathrm{Q}_{\mathrm{P} 50}=3.7566 \mathrm{E}-02$ DRNAREA $^{0.4168}(\mathrm{BSLDEM} \mathrm{DM}+0.001)^{1.3357}$ & 81.1 & \\
\hline $\mathrm{Q}_{\mathrm{P} 20}=9.6962 \mathrm{E}-02$ DRNAREA $^{0.4215}(\mathrm{BSLDEM} \mathrm{DM}+0.001)^{1.1148}$ & 78.6 & \\
\hline \multicolumn{3}{|l|}{ T: } \\
\hline $\mathrm{Q}_{\mathrm{P} 80}=1.9463 \mathrm{E}-01 \mathrm{DRNAREA}^{0.3956} 10^{0.3661 \mathrm{PRC} 2}$ & 85.1 & \multirow{3}{*}{37} \\
\hline $\mathrm{Q}_{\mathrm{P} 50}=3.0186 \mathrm{E}-01 \mathrm{DRNAREA}^{0.4320} 10^{0.3181 \mathrm{PRC} 2}$ & 82.2 & \\
\hline $\mathrm{Q}_{\mathrm{P} 20}=4.6752 \mathrm{E}-01$ DRNAREA ${ }^{0.4296} 10^{0.2930 \mathrm{PRC} 2}$ & 81.2 & \\
\hline \multicolumn{3}{|l|}{120} \\
\hline $\mathrm{Q}_{\mathrm{P} 80}=3.7827 \mathrm{E}-01$ DRNAREA ${ }^{0.5301} 10^{0.0072 \text { PRECIP + } 0.0100(\mathrm{SLOP} 30+0.001)}$ & 97.7 & \multirow{3}{*}{39} \\
\hline $\mathrm{Q}_{\mathrm{P} 50}=8.0168 \mathrm{E}-01 \mathrm{DRNAREA}^{0.5516} 10^{0.0005 \text { PRECIP }+0.0101(\mathrm{SLOP} 30+0.001)}$ & 91.7 & \\
\hline $\mathrm{Q}_{\mathrm{P} 20}=2.2167 \mathrm{E}+00 \mathrm{DRNAREA}^{0.5521} 10^{-0.0090 \text { PRECIP + } 0.0108(\mathrm{SLOP} 30+0.001)}$ & 92.5 & \\
\hline \multicolumn{3}{|l|}{$-\mathrm{T} 2 \mathrm{O}$} \\
\hline $\mathrm{Q}_{\mathrm{P} 80}=5.7836 \mathrm{E}+08$ DRNAREA $^{0.5743} \mathrm{ELEV}^{-2.1732}$ & 93.8 & \multirow{3}{*}{37} \\
\hline $\mathrm{Q}_{\mathrm{P} 50}=3.9382 \mathrm{E}+11 \mathrm{DRNAREA}^{0.6543} \mathrm{ELEV}^{-2.8657}$ & 73.8 & \\
\hline $\mathrm{Q}_{\mathrm{P} 20}=5.4702 \mathrm{E}+12$ DRNAREA $^{0.7783} \mathrm{ELEV}^{-3.1417}$ & 62.7 & \\
\hline \multicolumn{3}{|l|}{ 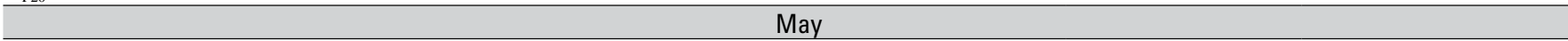 } \\
\hline $\mathrm{Q}_{\mathrm{P} 80}=2.8268 \mathrm{E}-01$ DRNAREA ${ }^{0.7487} 10^{0.0302 \text { PRECIP }}$ & 77.4 & \multirow{3}{*}{39} \\
\hline $\mathrm{Q}_{\mathrm{P} 50}=3.6559 \mathrm{E}-01$ DRNAREA ${ }^{0.8340} 10^{0.0322 \text { PRECIP }}$ & 62.8 & \\
\hline $\mathrm{Q}_{\mathrm{P} 20}=8.5921 \mathrm{E}-01 \mathrm{DRNAREA}^{0.8282} 10^{0.0290 \text { PRECIP }}$ & 57.9 & \\
\hline \multicolumn{3}{|l|}{ 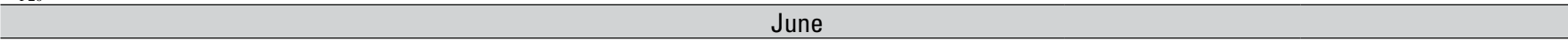 } \\
\hline $\mathrm{Q}_{\mathrm{P} 80}=1.7203 \mathrm{E}+00$ DRNAREA $^{-0.0444} 10^{0.7648 \text { PRC6 + } 0.0061 \text { (FOREST+0.001) }}$ & 149 & \multirow{3}{*}{39} \\
\hline $\mathrm{Q}_{\mathrm{P} 50}=3.2516 \mathrm{E}+00 \mathrm{DRNAREA}^{0.0124} 10^{0.7813 \text { PRC6 + } 0.0041 \text { (FOREST }+0.001)}$ & 140 & \\
\hline $\mathrm{Q}_{\mathrm{P} 20}=8.5251 \mathrm{E}-00$ DRNAREA ${ }^{0.0543} 10^{0.6672 \text { PRC } 6+0.0030(\text { FOREST+0.001) }}$ & 141 & \\
\hline \multicolumn{3}{|l|}{ 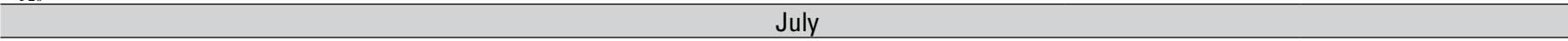 } \\
\hline $\mathrm{Q}_{\mathrm{P} 80}=5.7876 \mathrm{E}-16 \mathrm{DRNAREA}^{0.2398} \mathrm{ELEV}^{3.5772}(\mathrm{BSLDEM} \mathrm{BM}+0.001)^{1.5323}$ & 119 & \multirow{3}{*}{38} \\
\hline $\mathrm{Q}_{\mathrm{P} 50}=5.4488 \mathrm{E}-15$ DRNAREA $^{0.2913}$ ELEV $^{3.5357}(\mathrm{BSLDEM} 10 \mathrm{M}+0.001)^{1.0531}$ & 105 & \\
\hline $\mathrm{Q}_{\mathrm{P} 20}=1.7346 \mathrm{E}-15 \mathrm{DRNAREA}^{0.3558} \mathrm{ELEV}^{3.8161}(\mathrm{BSLDEM} 10 \mathrm{M}+0.001)^{0.7038}$ & 102 & \\
\hline \multicolumn{3}{|l|}{$\begin{array}{ll} & \text { August } \\
\end{array}$} \\
\hline $\mathrm{Q}_{\mathrm{P} 80}=4.0244 \mathrm{E}-12 \mathrm{DRNAREA}^{0.2355} \mathrm{ELEV}^{2.5456}(\mathrm{BSLDEM} \mathrm{BM}+0.001)^{1.5444}$ & 94.4 & \multirow{3}{*}{37} \\
\hline $\mathrm{Q}_{\mathrm{P} 50}=1.6535 \mathrm{E}-11 \mathrm{DRNAREA}^{0.2693} \mathrm{ELEV}^{2.5251}(\mathrm{BSLDEM} \mathrm{DM}+0.001)^{1.2482}$ & 93.2 & \\
\hline $\mathrm{Q}_{\mathrm{P} 20}=7.2410 \mathrm{E}-12 \mathrm{DRNAREA}^{0.3286} \mathrm{ELEV}^{2.7303}(\mathrm{BSLDEM} \mathrm{BM}+0.001)^{0.9900}$ & 91.6 & \\
\hline $\begin{array}{ll} & \text { Septer } \\
\end{array}$ & & \\
\hline $\mathrm{Q}_{\mathrm{P} 80}=1.3140 \mathrm{E}-02$ DRNAREA $^{0.2456}(\mathrm{BSLDEM} \mathrm{DM}+0.001)^{1.0630} 10^{0.0319 \text { PRECIP }}$ & 95.1 & \\
\hline $\mathrm{Q}_{\mathrm{P} 50}=3.4340 \mathrm{E}-02 \mathrm{DRNAREA}^{0.3116}(\mathrm{BSLDEM} \mathrm{DM}+0.001)^{0.7939} 10^{0.0319 \text { PRECIP }}$ & 95.4 & 37 \\
\hline $\mathrm{Q}_{\mathrm{P} 20}=8.6139 \mathrm{E}-02 \mathrm{DRNAREA}^{0.3815}(\mathrm{BSLDEM} 10 \mathrm{M}+0.001)^{0.7265} 10^{0.0313 \text { PRECIP }}$ & 96.6 & \\
\hline $\begin{array}{ll} & \text { Annual } \\
\end{array}$ & & \\
\hline $\mathrm{Q}_{\text {ANNMEAN }}=6.5751 \mathrm{E}-02$ DRNAREA $^{0.7838} 10^{0.0453 \text { PRECIP }}$ & 44.2 & 39 \\
\hline
\end{tabular}


Table 4. Regression equations and their associated uncertainty for estimating monthly 80-, 50-, and 20-percent exceedance streamflows for natural streams in region 2 in Utah.

[Regression variables: $\mathrm{Q}_{\mathrm{P} 80}$, daily mean discharge exceeded 80 percent of the time during the specified month, in cubic feet per second; $\mathrm{Q}_{\mathrm{P} 50}$, daily mean discharge exceeded 50 percent of the time during the specified month, in cubic feet per second; $\mathrm{Q}_{\mathrm{p} 20}$, daily mean discharge exceeded 20 percent of the time during the specified month, in cubic feet per second; DRNAREA, drainage area, in square miles; ELEV, mean basin elevation, in feet; PRECIP, mean annual precipitation, in inches; PRC8, mean August precipitation, in inches; $\mathrm{Q}_{\mathrm{ANNMEAN}}$, annual mean discharge, in cubic feet per second]

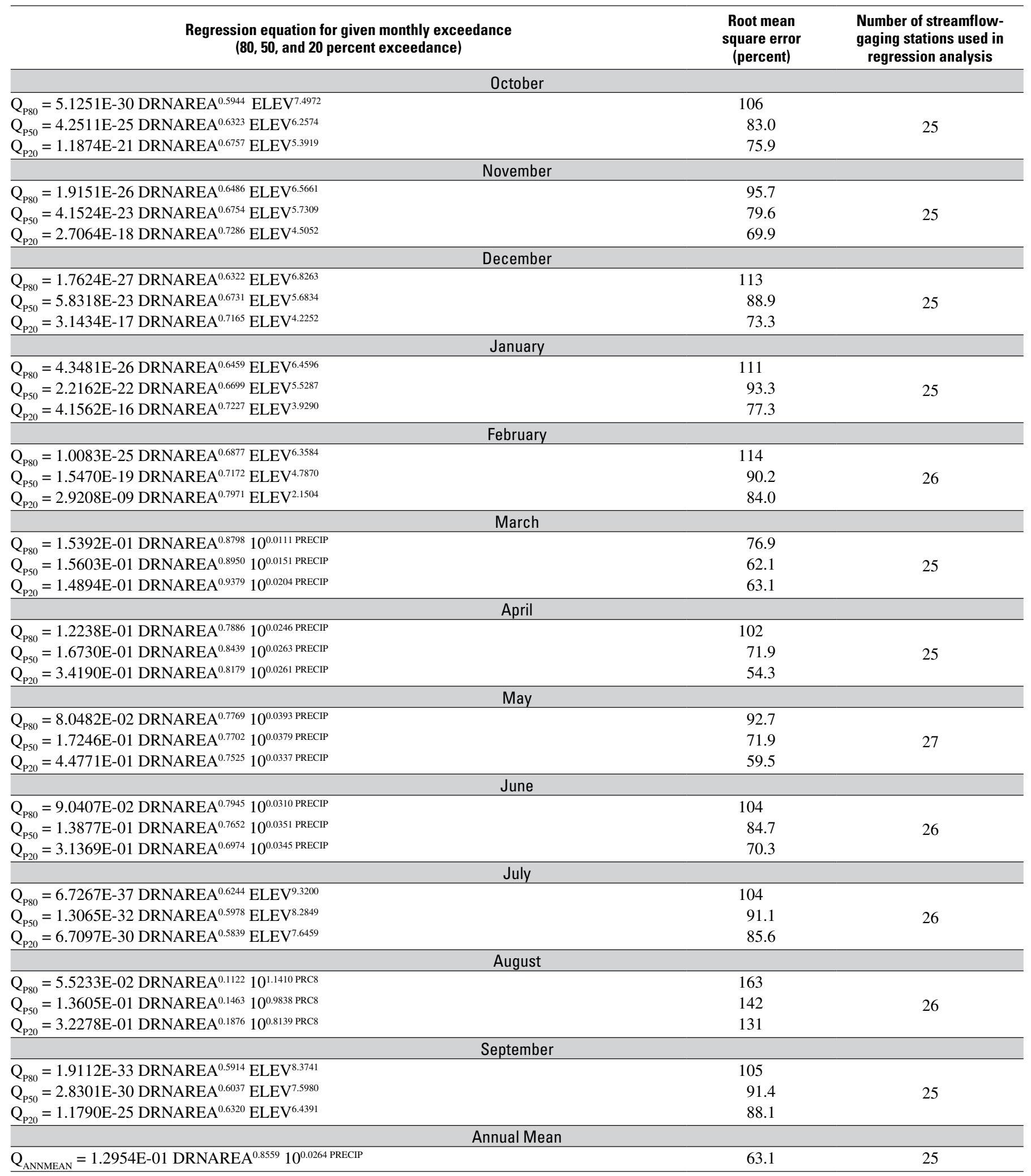


Table 5. Regression equations and their associated uncertainty for estimating monthly 80-, 50-, and 20-percent exceedance streamflows for natural streams in region 4 in Utah.

[Regression variables: $\mathrm{Q}_{\mathrm{P} 80}$, daily mean discharge exceeded 80 percent of the time during the specified month, in cubic feet per second; $\mathrm{Q}_{\mathrm{P} 50}$, daily mean discharge exceeded 50 percent of the time during the specified month, in cubic feet per second; $\mathrm{Q}_{\mathrm{p} 20}$, daily mean discharge exceeded 20 percent of the time during the specified month, in cubic feet per second; DRNAREA, drainage area, in square miles; ELEV, mean basin elevation, in feet; PRECIP, mean annual precipitation, in inches;

$\mathrm{Q}_{\text {ANNMEAN }}$, annual mean discharge, in cubic feet per second]

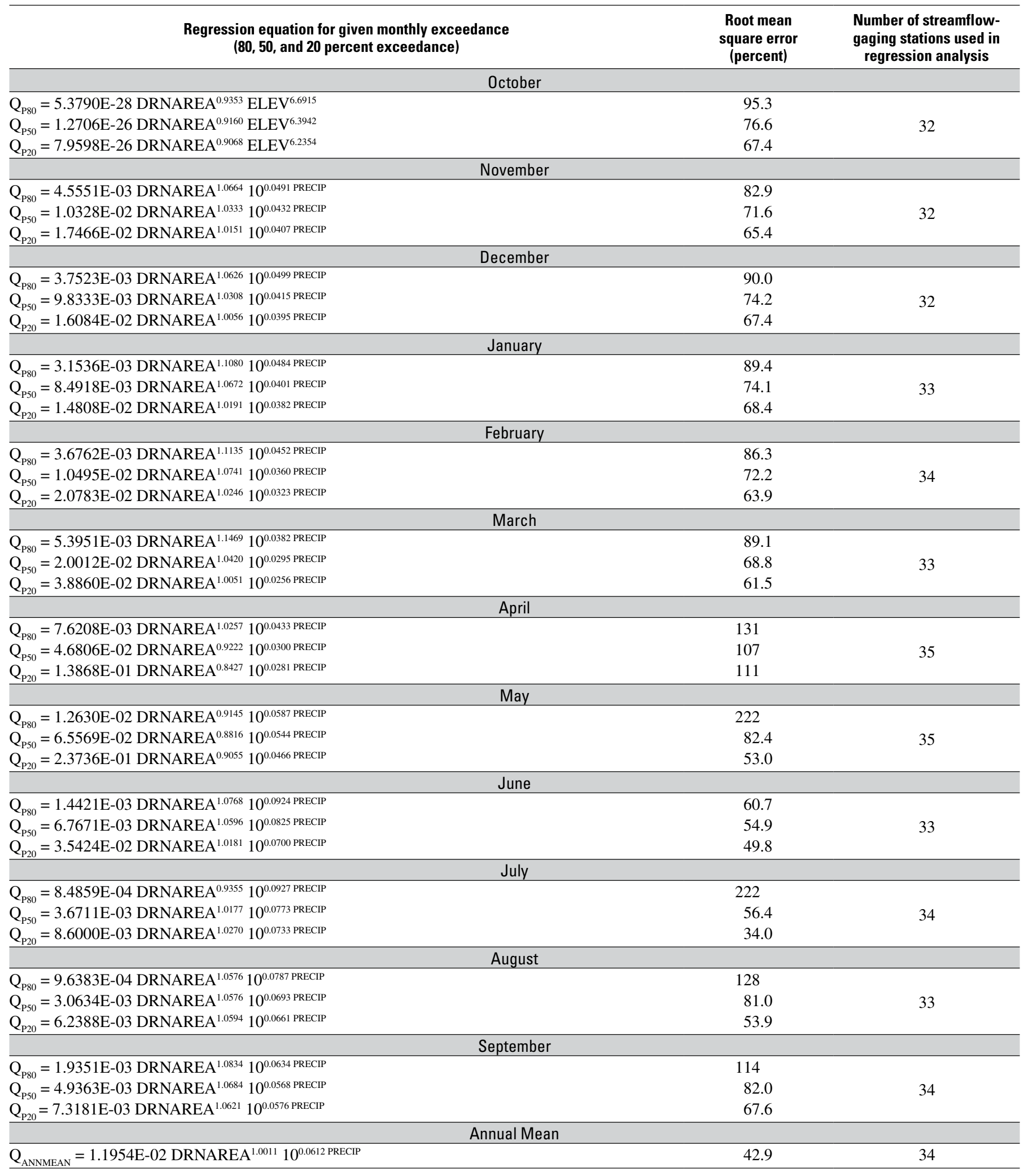


Table 6. Regression equations and their associated uncertainty for estimating monthly 80-, 50-, and 20-percent exceedance streamflows for natural streams in region 6 in Utah.

[Regression variables: $\mathrm{Q}_{\mathrm{P} 80}$, daily mean discharge exceeded 80 percent of the time during the specified month, in cubic feet per second; $\mathrm{Q}_{\mathrm{P} 50}$, daily mean discharge exceeded 50 percent of the time during the specified month, in cubic feet per second; $\mathrm{Q}_{\mathrm{p} 20}$, daily mean discharge exceeded 20 percent of the time during the specified month, in cubic feet per second; DRNAREA, drainage area, in square miles; PRECIP, mean annual precipitation, in inches; PRC11, mean November precipitation, in inches; PRC12, mean December precipitation, in inches; PRC1, mean January precipitation, in inches; PRC2, mean February precipitation, in inches; PRC3, mean March precipitation, in inches; PRC7, mean July precipitation, in inches; $\mathrm{Q}_{\mathrm{ANNMEAN}}$, annual mean discharge, in cubic feet per second]

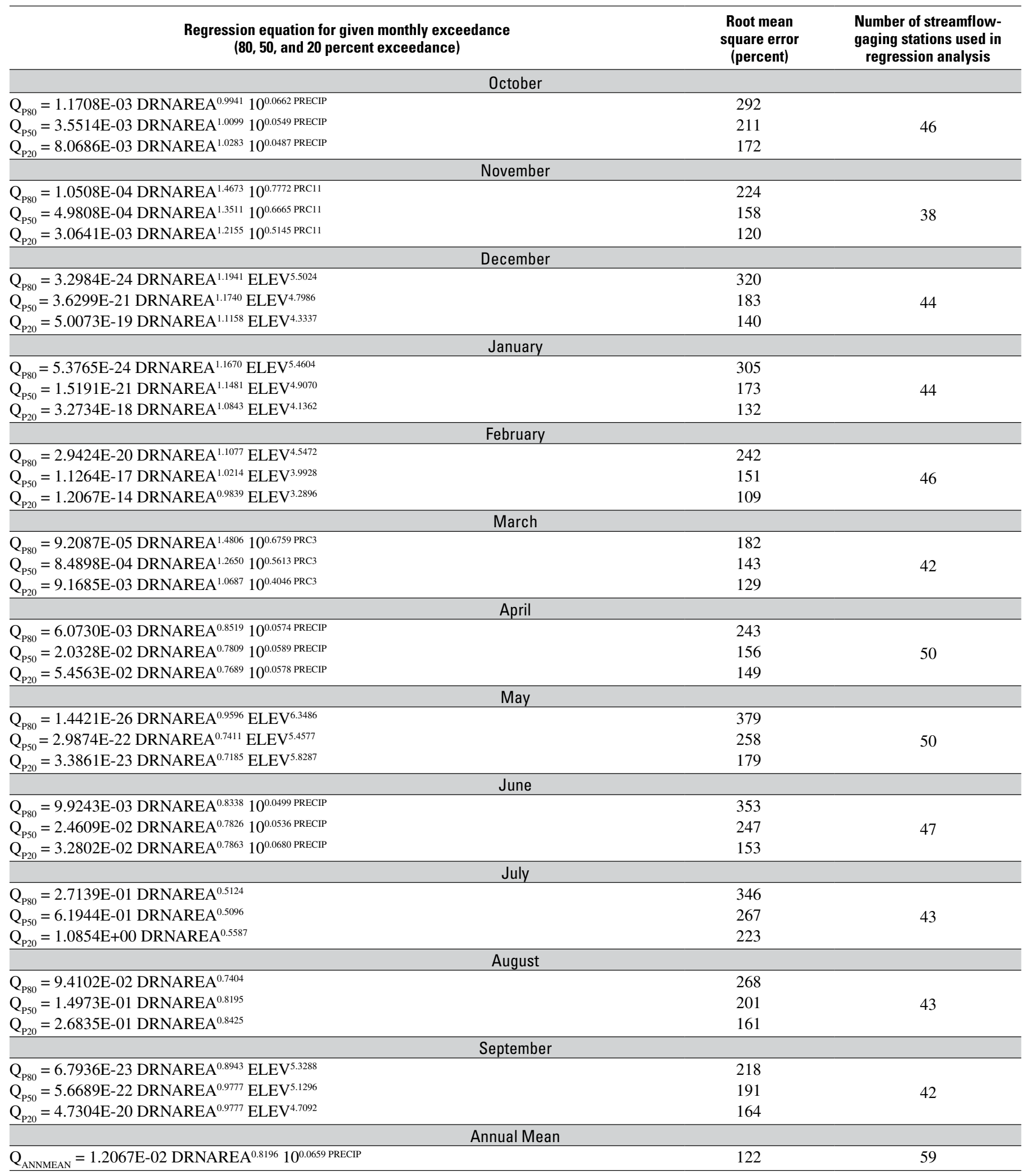


Table 7. Regression equations and their associated uncertainty for estimating monthly 80-, 50-, and 20-percent exceedance streamflows for natural streams in region 7 in Utah.

[Regression variables: $\mathrm{Q}_{\mathrm{P} 80}$, daily mean discharge exceeded 80 percent of the time during the specified month, in cubic feet per second; $\mathrm{Q}_{\mathrm{P} 50}$, daily mean discharge exceeded 50 percent of the time during the specified month, in cubic feet per second; $\mathrm{Q}_{\mathrm{P} 20}$, daily mean discharge exceeded 20 percent of the time during the specified month, in cubic feet per second; DRNAREA, drainage area, in square miles; ELEV, mean elevation, in feet; $\mathrm{Q}_{\mathrm{ANNMEAN}}$, annual mean discharge, in cubic feet per second]

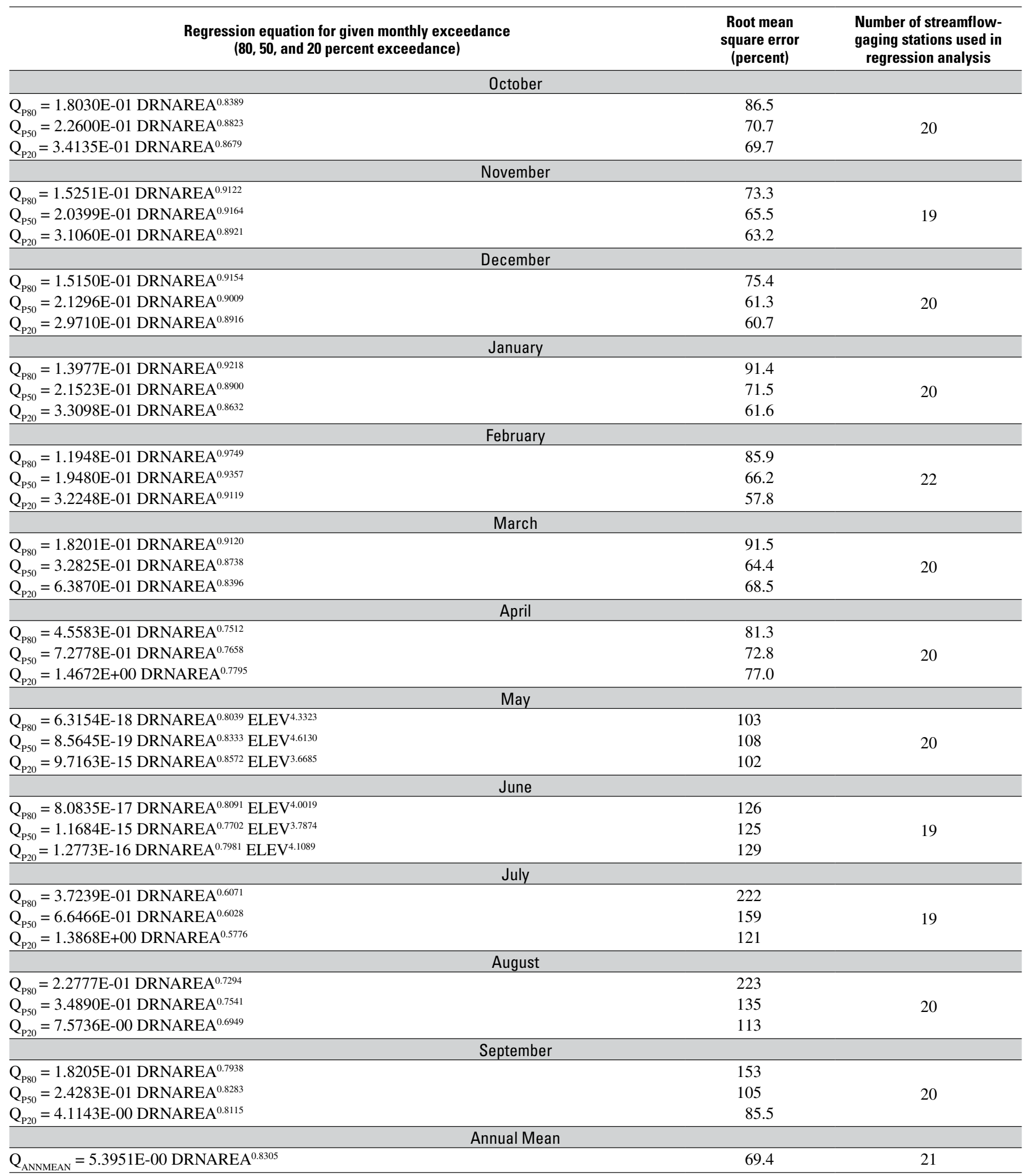


Table 8. Regression equations and their associated uncertainty for estimating monthly 80-, 50-, and 20-percent exceedance streamflows for natural streams in combined region 3 and region 5 in Utah.

[Regression variables: $\mathrm{Q}_{\mathrm{P} 80}$, daily mean discharge exceeded 80 percent of the time during the specified month, in cubic feet per second; $\mathrm{Q}_{\mathrm{P} 50}$, daily mean discharge exceeded 50 percent of the time during the specified month, in cubic feet per second; $\mathrm{Q}_{\mathrm{p} 20}$, daily mean discharge exceeded 20 percent of the time during the specified month, in cubic feet per second; DRNAREA, drainage area, in square miles; PRC10, mean October precipitation, in inches; PRC11, mean November precipitation, in inches; PRC12, mean December precipitation, in inches; PRC1, mean January precipitation, in inches; PRC2, mean February precipitation, in inches; HERBNAT_ NLCD92, area covered by herbaceous upland, in percent; FOREST, area covered by forest, in percent; ELEV, mean basin elevation, in feet; PRECIP, mean annual precipitation, in inches; PRC9, mean September precipitation, in inches; $\mathrm{Q}_{\mathrm{ANNMEAN}}$, annual mean discharge, in cubic feet per second]

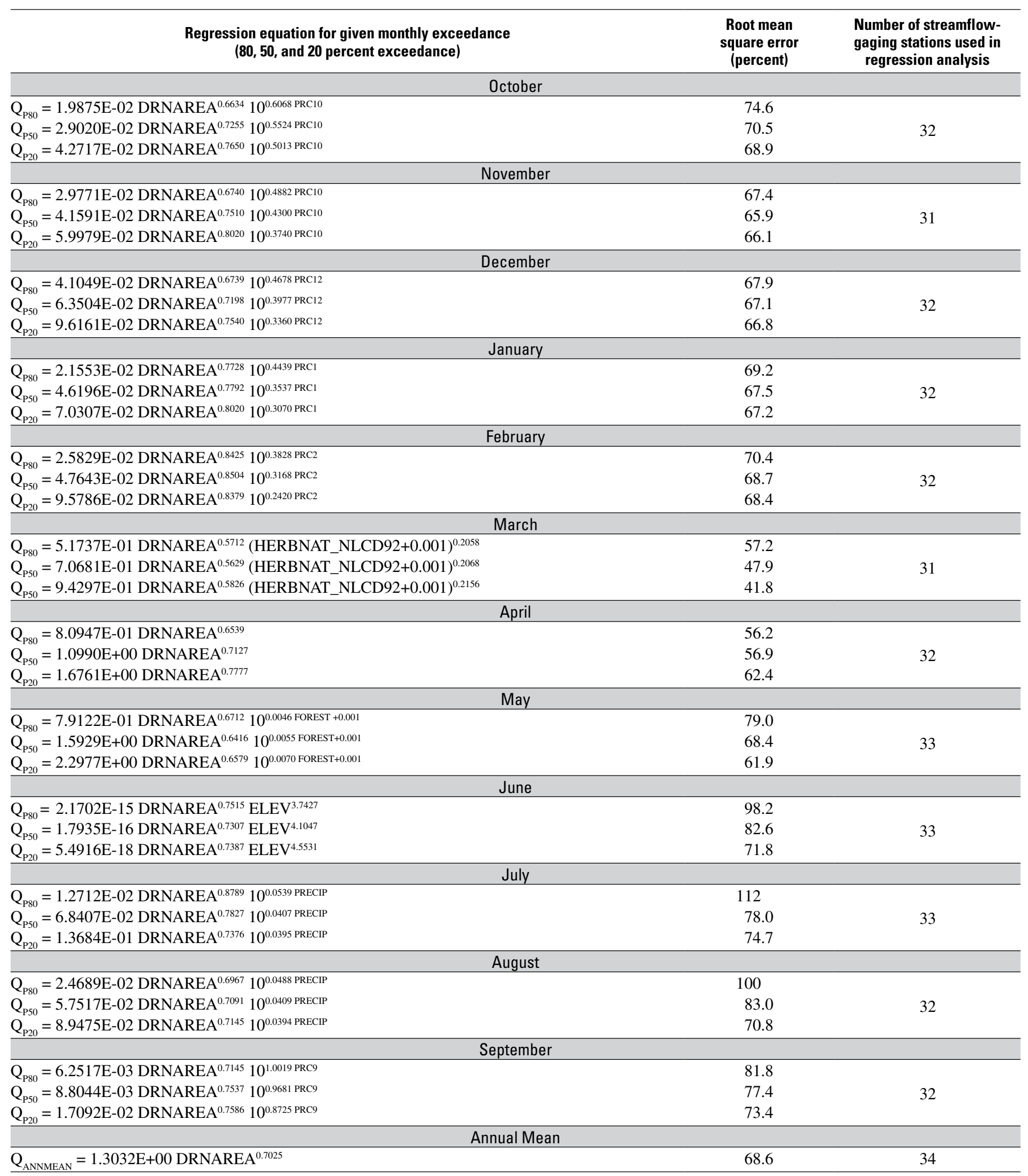


Table 9. Root mean square error percent associated with the monthly exceedance streamflow and annual mean streamflow regression equations for all regions, Utah.

[Regression variables: $\mathrm{Q}_{\mathrm{P} 80}$, 80-percent exceedance streamflow equation; $\mathrm{Q}_{\mathrm{P} 50}$, 50-percent exceedance streamflow equation; $\mathrm{Q}_{\mathrm{P} 20}$, 20-percent exceedance streamflow equation; Annual mean, Annual mean streamflow equation]

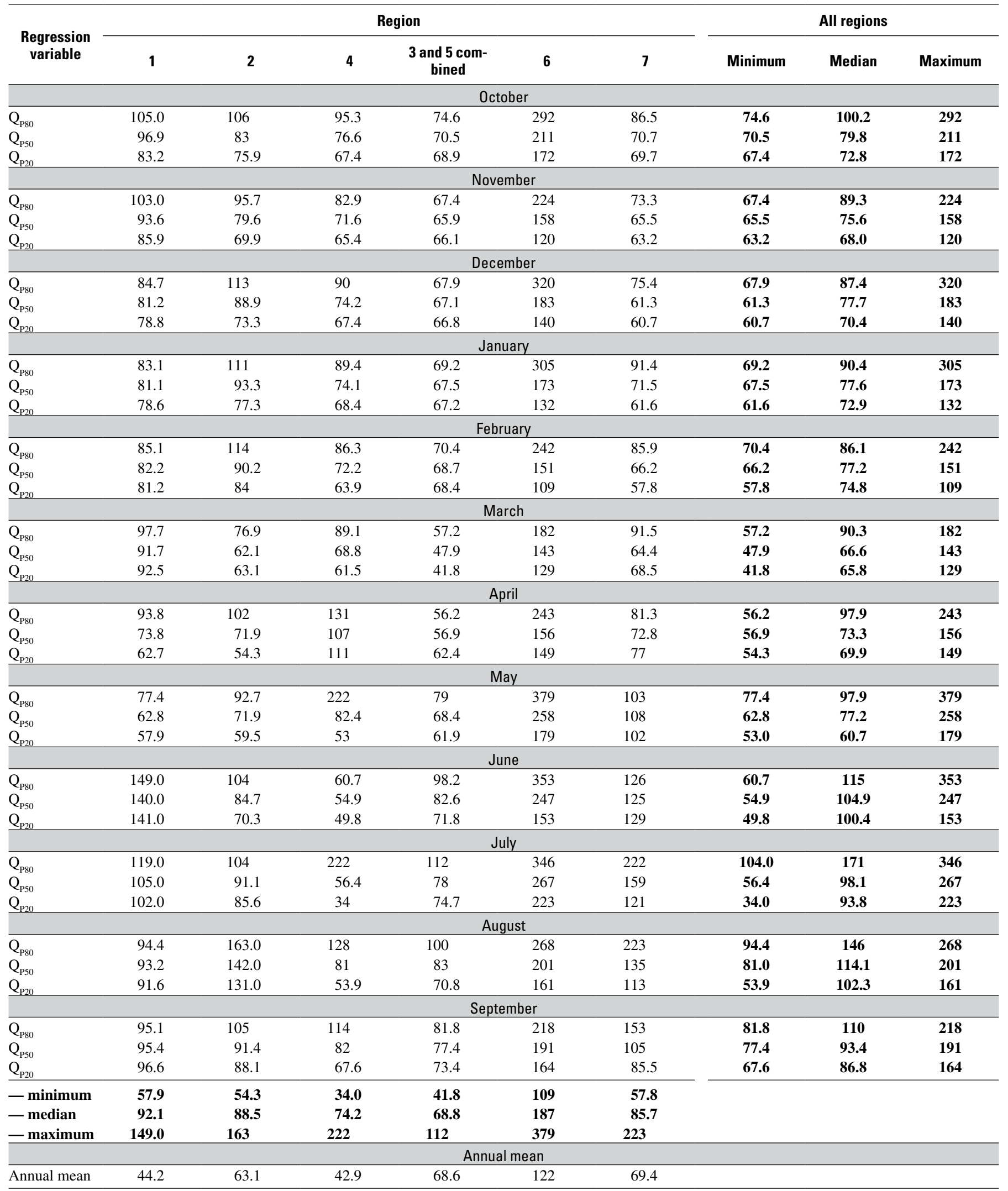




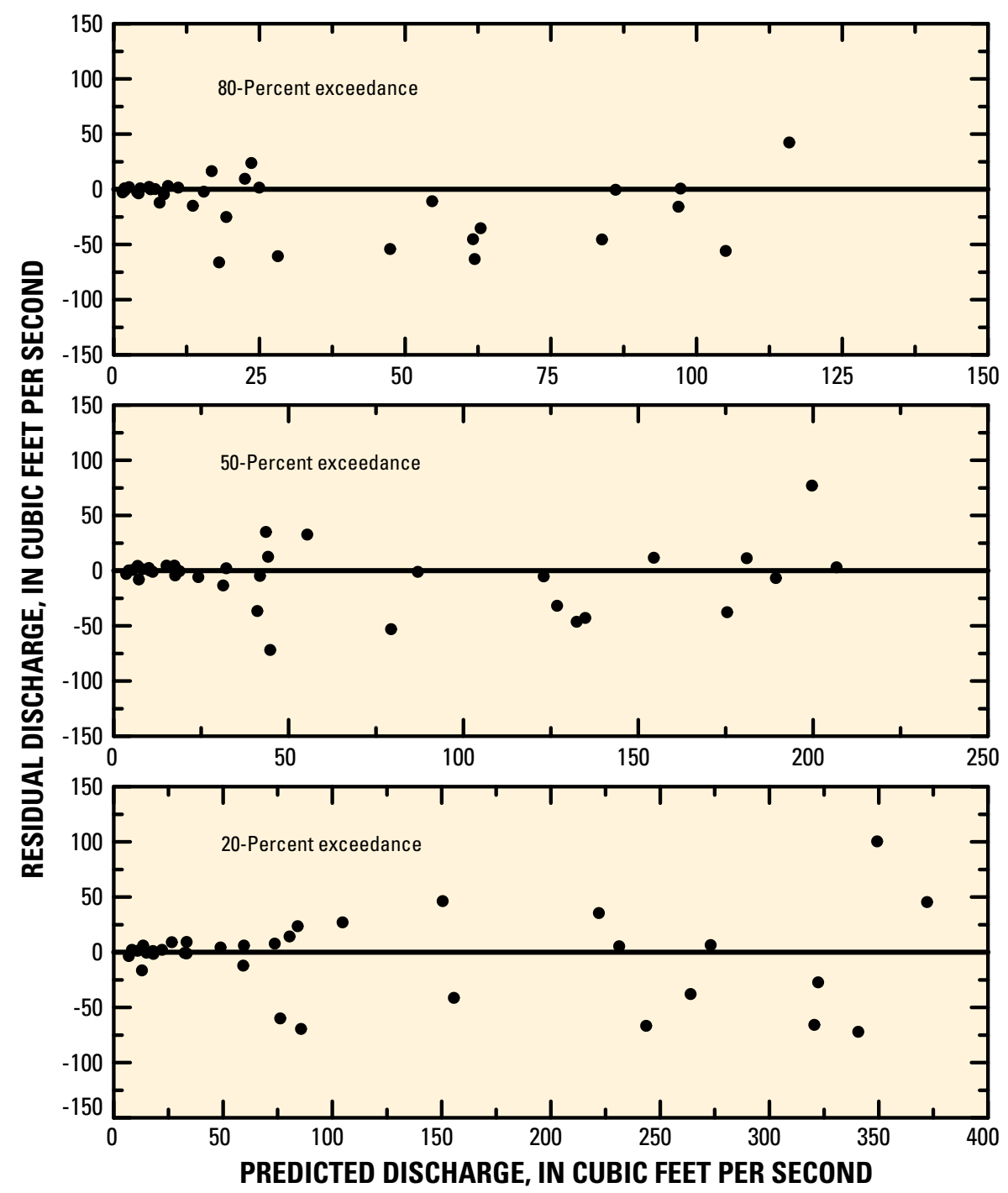

Figure 3. Residuals for the July exceedance equations for region 4 in Utah.

in Utah is driven by total annual precipitation that falls in the winter as snow and runs off into streams as snowmelt in the spring. Mean monthly precipitation was mostly used in region 6 where high streamflows can occur any time of year as a result of rapid runoff over exposed bedrock. Mean basin slope and slope percentage greater than 30 percent were used almost exclusively in region 1 . Forest percentage was used for the May equations in region 1 and the June equations in combined regions 3 and 5. Streamflow of most streams in these regions during May and June is attributed to high-elevation snowmelt runoff and may explain why these variables are useful at these times. The percentage of herbaceous upland was used only in the equations for combined regions 3 and 5 for the month of March. Low- to mid-elevation streams in most of Utah often experience peak streamflows in March as lower elevation snow starts to runoff. The percentage of herbaceous upland is likely the basin characteristic most representative of these areas.

\section{Limitations of Regional Regression Equations}

The regression equations are not valid for streams that are significantly affected by irrigation diversions or large dams that regulate streamflow. The equations contained in this report were developed using predictor variables derived from the datasets described in tables 1 and 2. The range of these predictor variables is shown in table 11 . The regression equations should not be used on streams where the basin characteristics are outside the range of those listed in table 11. In addition, the associated error for the equations in this report, are only valid if the same datasets, scales, and computational methods are used to calculate the predictor variables.

StreamStats uses the National Hydrography Dataset (NHD) for the stream coverage. The NHD in StreamStats does not differentiate between perennial, ephemeral, or intermittent streams. Because intermittent and ephemeral streams were not used in the development of the regression equations in this 


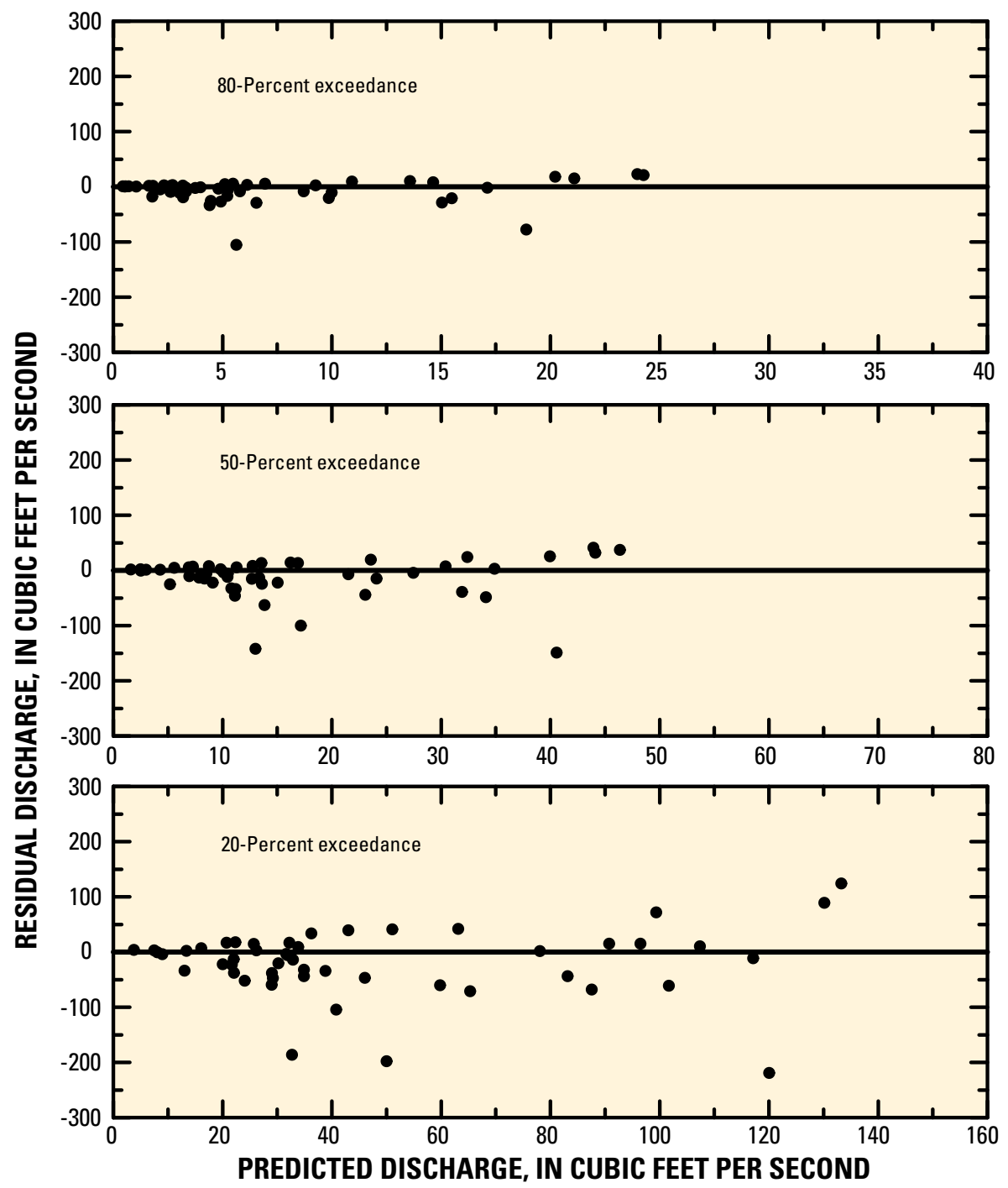

Figure 4. Residuals for the July exceedance equations for region 6 in Utah.

Table 10. Basin physiographic and climatic characteristics used in the monthly exceedance and annual mean regression equations for Utah.

[xx, numeric value of month]

\begin{tabular}{llc}
\hline \multicolumn{1}{c}{ Characteristic } & $\begin{array}{c}\text { Streamstats characteristic } \\
\text { abbreviation }\end{array}$ & $\begin{array}{c}\text { Percentage of equations where } \\
\text { characteristic is used }\end{array}$ \\
\hline Drainage area & DRNAREA & 100 \\
Mean annual precipitation & PRECIP & 40 \\
Mean monthly precipitation & PRCxx & 22 \\
Mean basin elevation & ELEV & 19 \\
Mean basin slope & BSLDEM10M & 7 \\
Percentage of basin slope greater than 30 percent & SLOP30 & 3 \\
Percentage of area covered by forest & FOREST & 3 \\
Percentage of area covered by herbaceous upland & HERBNAT_NLCD92 & 1 \\
\hline
\end{tabular}




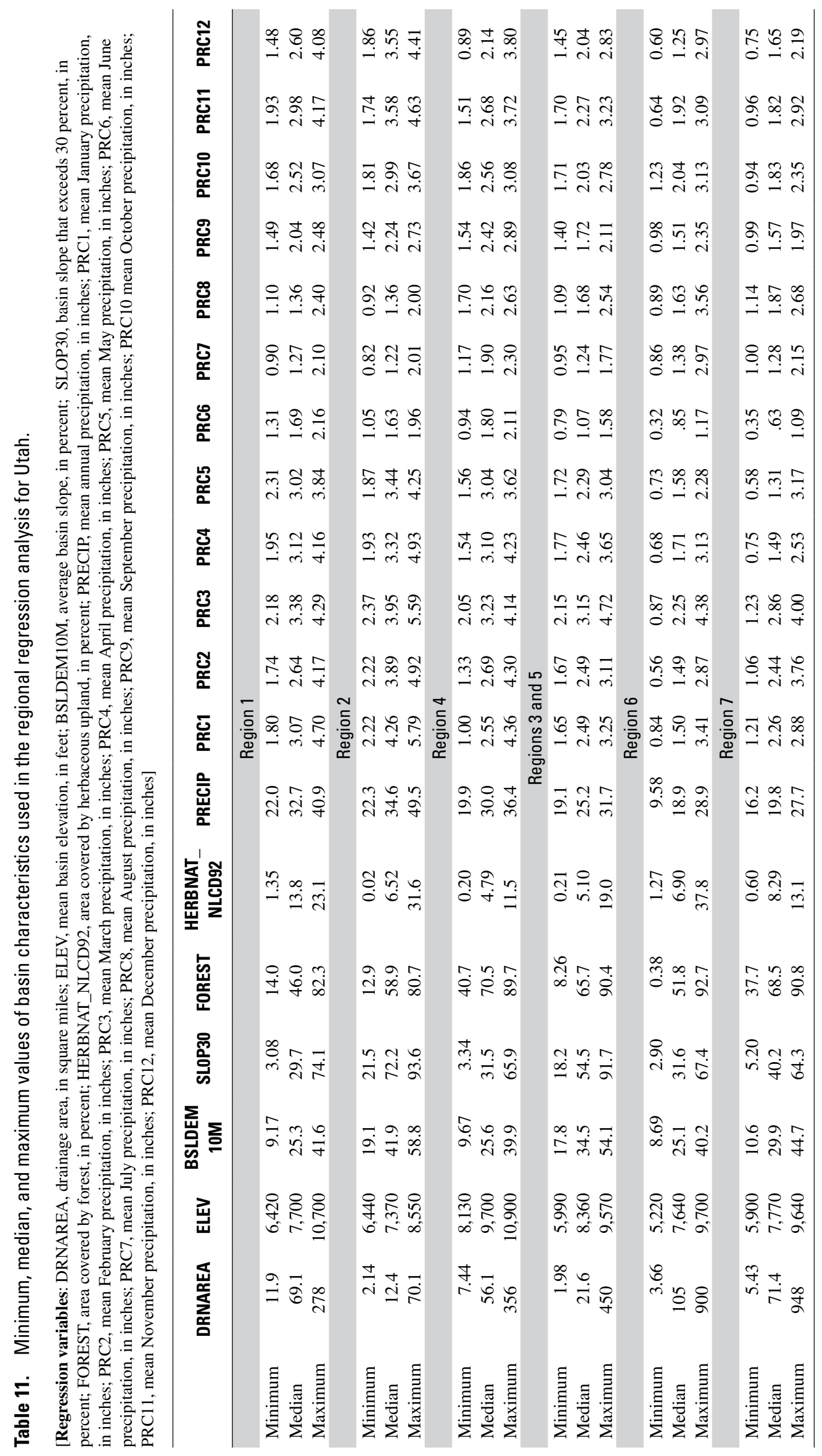


report, caution should be used if a stream is suspected to be nonperennial. For these cases, the predicted streamflow will most likely be biased high. Limitations to the range of drainage basin area, and the effect of dam regulation, mean that the equations are not valid for some of the major rivers in the state including the Colorado River, the Green River, the San Juan River, and the Bear River below Woodruff Narrows Reservoir.

\section{Summary}

Monthly and annual streamflow information is required by those who manage fish and wildlife, water rights, and other land-use areas to assist in their decision-making processes. This type of information is available at sites where streamflow-gaging stations are located; however, there are numerous drainage basins in Utah with no existing streamflow information. Estimates are therefore needed for monthly and annual streamflow statistics in these areas. The monthly 80-, $50-$, and 20-percent exceedance streamflow was calculated for 266 streamflow-gaging stations in Utah and surrounding states. Using GIS software, 24 physiographic and climatic basin characteristics were computed for each gaging station location. Using these data, regional regression equations that can be used to predict monthly 80-, 50-, and 20-percent exceedance streamflow and annual mean streamflow at ungaged sites in Utah were created. The state of Utah was divided into seven distinct geohydrologic regions on the basis of a variety of physiographic, climatic, and hydrologic characteristics. Separate regression equations were developed for each region except region 3 , which was combined with region 5 because of the small number of gaging stations in region 3 . Root mean square error percent for the equations ranged from 34 to 379 percent. Region 6 in Utah had the greatest amount of error associated with its predicting equations, whereas combined regions 3 and 5 had the least amount of error. July was generally the month with the greatest error for all regions. The equations are more reliable for predicting high streamflow statistics (20-percent exceedance) than for predicting the low streamflow statistics (80-percent exceedance). In general, the mean annual streamflow equations had smaller error than the monthly predicting equations. The error associated with the equations in this report is only valid if the equations are used with the same datasets, scales, and computational methods that were used to calculate the predictor variables. The equations and their associated errors should be considered valid only if used over the range of variables listed in table 11. The equations documented in this report will be implemented in StreamStats, a USGS Web-based tool that allows users to delineate drainage basins and calculate various streamflow statistics.

\section{References Cited}

Aitchison, J., and Brown, J.A.C., 1957, The log-normal distribution: Cambridge, United Kingdom, Cambridge University Press.

Bonnin, G., Martin, D., Parzybok, T., Lin, B., Riley, D., and Yekta, M., 2006, Precipitation frequency atlas of the United States: National Weather Service, National Oceanic and Atmospheric Administration Atlas 14, vol. 1, version 4.0, accessed July 12, 2007, at http://hdsc.nws.noaa.gov/hdsc/ pfds/docs/NA14Voll.pdf.

Christensen, R.C., Johnson, E.B., and Plantz, G.G., 1985, Manual for estimating selected streamflow characteristics of natural-flow streams in the Colorado River Basin in Utah: U.S. Geological Survey Water-Resources Investigations Report 85-4297, 39 p.

Cruff, R.W., 1975, Estimating mean streamflow in the Duchesne River Basin, Utah: State of Utah Department of Natural Resources Technical Publication No. 48, 18 p.

Daly, C., Nielson, R.P., and Phillips, D.L., 1994, A statisticaltopographic model for mapping climatological precipitation over mountainous terrain: Journal of Applied Meteorology, v. 33, no. 2, p. 140-158, accessed July 12, 2007 and August 29, 2007, at http://prism.oregonstate.edu/products/.

Environmental Systems Research Institute, Inc., 1999, Getting started with Arc/Info: Redlands, California, Environmental Systems Research Institute, Inc., 230 p.

Fields, F.K., 1975, Estimating streamflow characteristics for streams in Utah using selected channel-geometry parameters: U.S. Geological Survey Water-Resources Investigations Report 74-34, 19 p.

Fields, F.K., and Adams, D.B., 1976, Climatic and streamflow estimates for northeastern Utah: U.S. Geological Survey Open-File Report 75-673, 47 p.

Helsel, D.R., and Hirsch, R.M., 1992, Statistical methods in water resources, Amsterdam, The Netherlands, Elsevier Science Publishers.

Hortness, J.E., and Berenbrock, C., 2001, Estimating monthly and annual streamflow statistics at ungaged sites in Idaho: U.S. Geological Survey Water-Resources Investigations Report 01-4093, 36 p.

Insightful Corporation, 2005, S-Plus 7 for Windows user's guide: Seattle, Washington, Insightful Corporation, 654 p.

Kenney, T.A., Wilkowske, C.D., and Wright, S.J., 2007, Methods for estimating magnitude and frequency of peak streamflows for natural streams in Utah: U.S. Geological Survey Scientific Investigations Report 2007-5158, 28 p. 
Miller, J.F., Frederick, R.H., and Tracy, R.J., 1973, Precipitation-frequency atlas of the Western United States: National Weather Service, National Oceanic and Atmospheric Administration Atlas 2, 11 vols., accessed July 12, 2007, at http://nws.noaa.gov/ohd/hdsc/noaaatlas2.htm

National Oceanic and Atmospheric Administration, 1994, Location of U.S. climate divisions: Boulder Colorado, National Oceanic and Atmospheric Administration Earth System Research Lab Physical Sciences Division, accessed April 30, 2007, at http://www.cdc.noaa.gov/usclimate/map. html.

Ries III, K.G., Steeves, P.A., Coles, J.D., Rea, A.H., and Stewart, D.W., 2004, StreamStats: A U.S. Geological Survey web application for stream information: U.S. Geological Survey Fact Sheet 2004-3115, 4 p.

Riggs, H.C., 1969, Mean streamflows from discharge measurements: International Association of Scientific Hydrology Bulletin XIV, v. 4, p. 95-110.

Riggs, H.C., 1972, Low-flow investigations: U.S. Geological Survey Techniques of Water-Resources Investigations, book 4, chapter B1, $18 \mathrm{p}$.

Stedinger, J.R., and Tasker, G.D., 1985, Regional hydrologic analysis I-Ordinary, weighted, and generalized least squares compared: Water Resources Research, v. 21, no. 9, p. 1421-1432.

Tasker, G.D., and Stedinger, J.R., 1989, An operational GLS model for hydrologic regression: Journal of Hydrology, v. 111, p. 361-375.

Thomas, B.E., Hjalmarson, H.W., and Waltemeyer, S.D., 1997, Methods for estimating magnitude and frequency of floods in the southwestern United States: U.S. Geological Survey Water-Supply Paper 2433, $195 \mathrm{p}$.

U.S. Geological Survey, 1999, National elevation dataset: U.S. Geological Survey Fact Sheet 148-99, accessed July 12, 2007, at http://erg.usgs.gov/isb/pubs/factsheets/fs14899.html

Utah Geological Survey, 2007, Physiographic regions of Utah: Utah Geological Survey, accessed on April 30, 2007, at http://ugs.utah.gov/emp/geothermal/physiography_utah. htm.

Vogelmann, J.E., Sohl, T.L., Campbell, P.V., and Shaw, D.M., 1998, Regional land cover characterization using Landsat Thematic Mapper data and ancillary data sources: Environmental Monitoring and Assessment, v. 51, p. 415-428.

Whitaker, G.L., 1971, A proposed streamflow data program for Utah: U.S. Geological Survey Open-File Report, 46p. 


\section{Appendix A.}




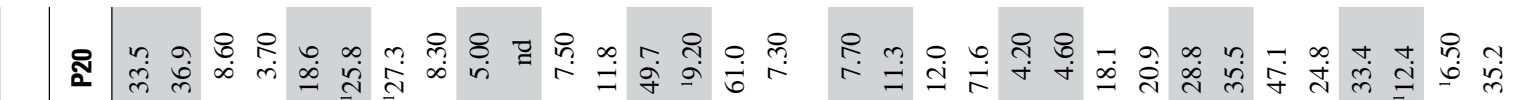
产

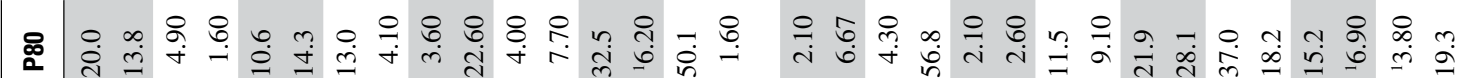

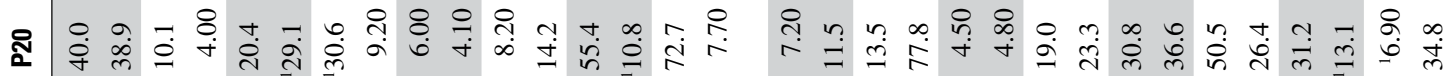

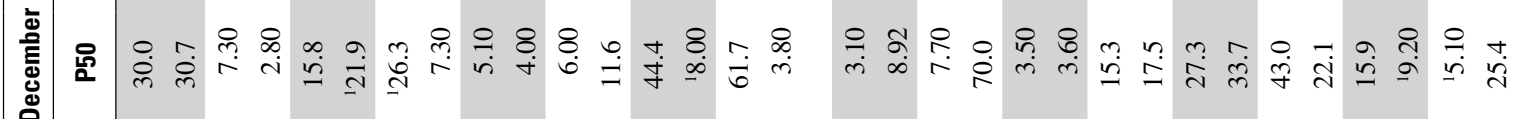

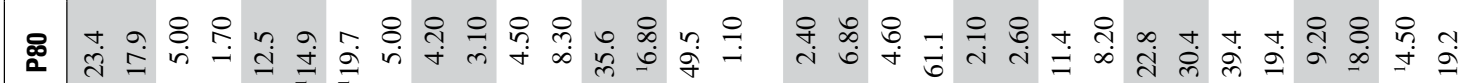

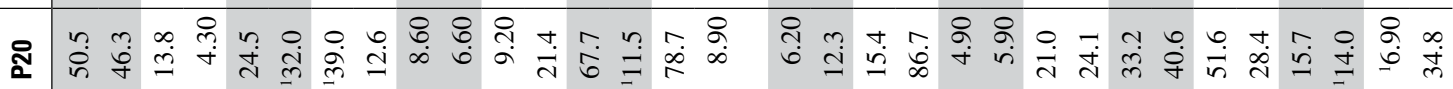

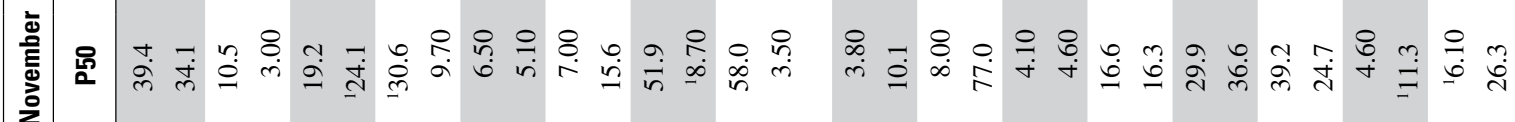
ஐ

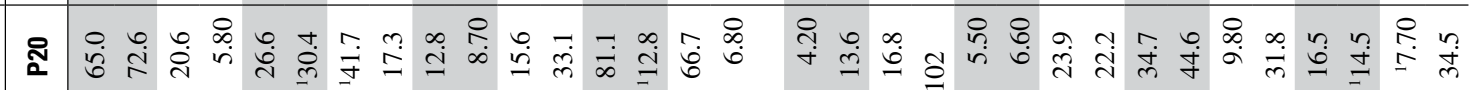

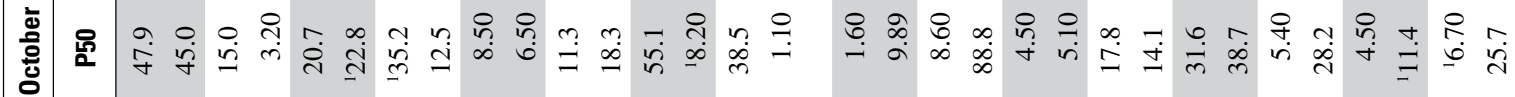

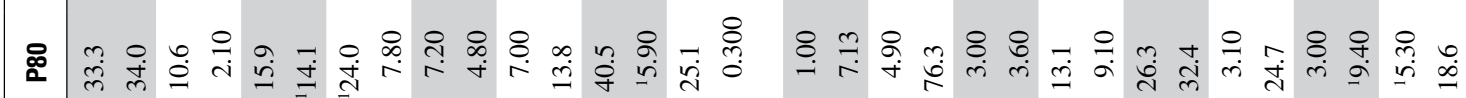

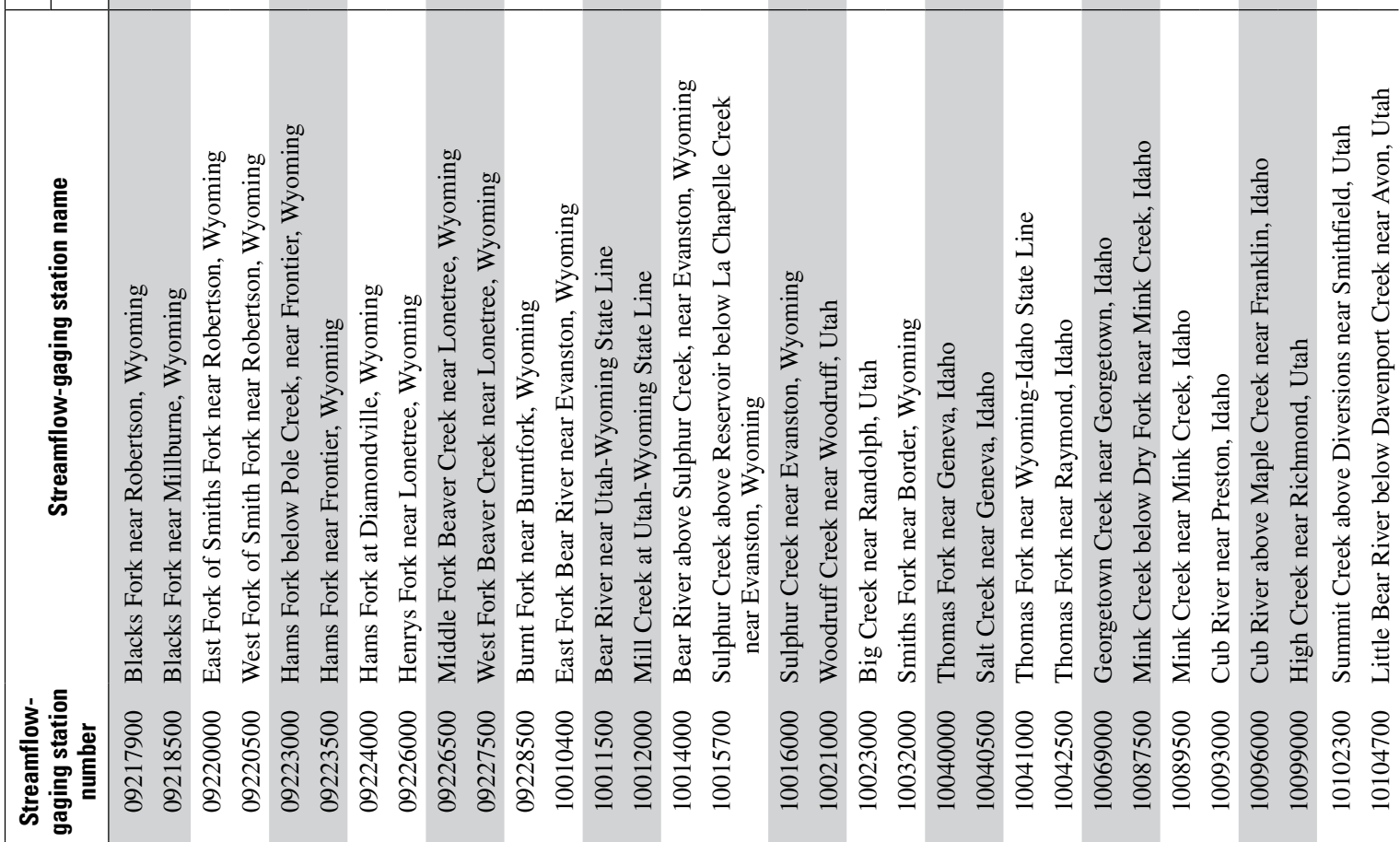

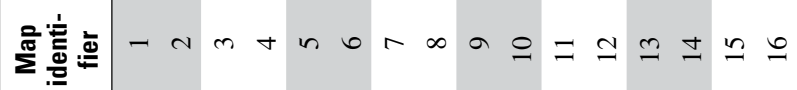
Iอง 


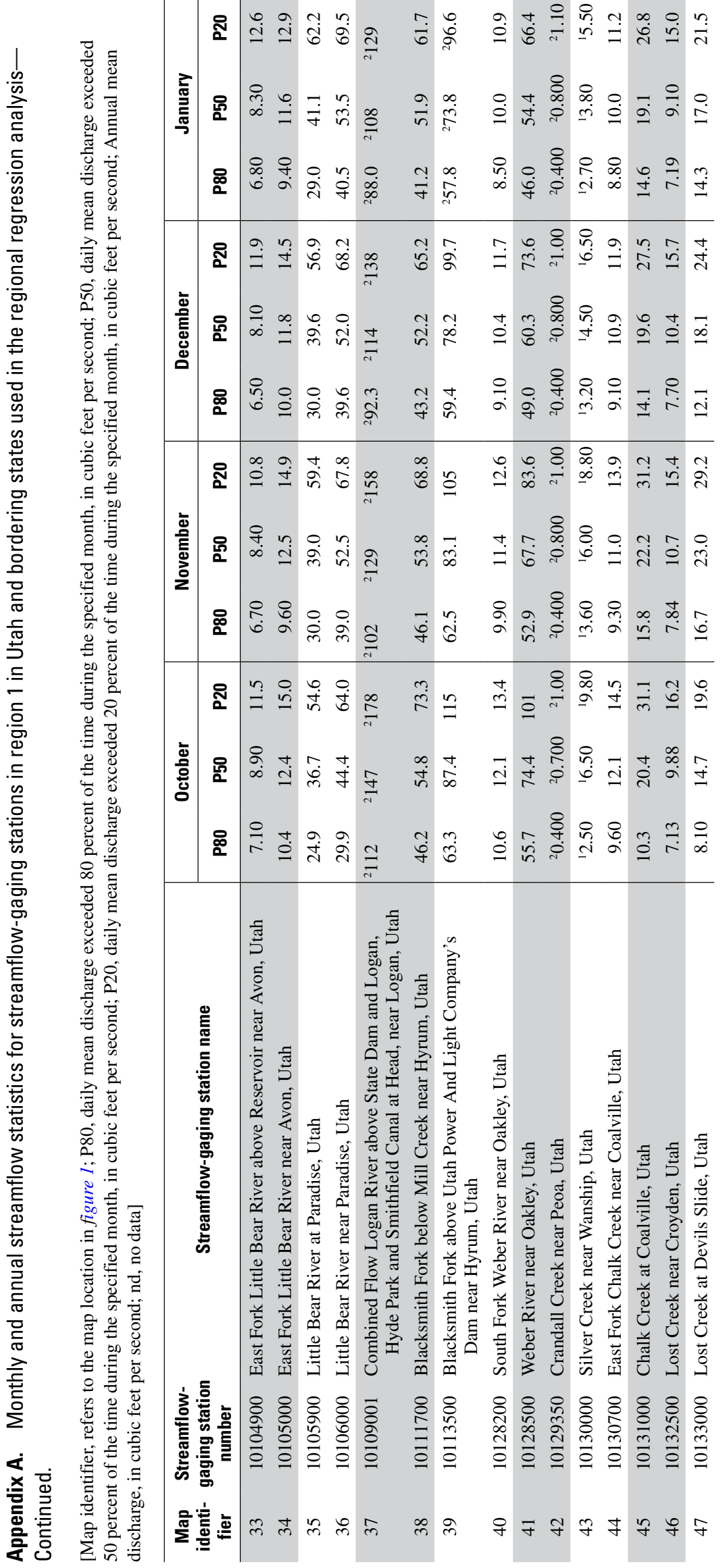




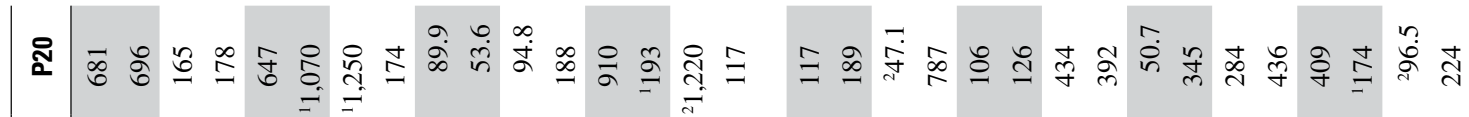

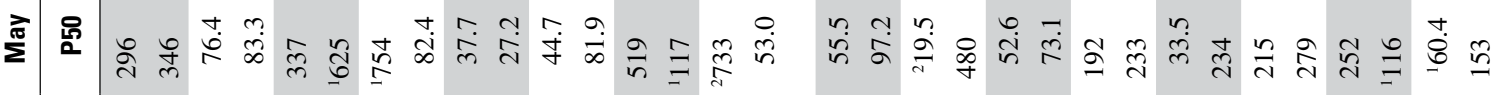

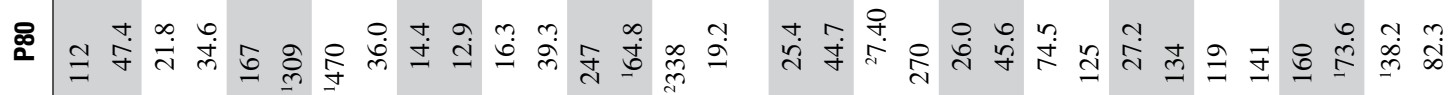

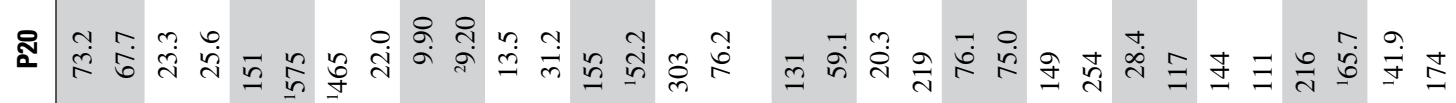

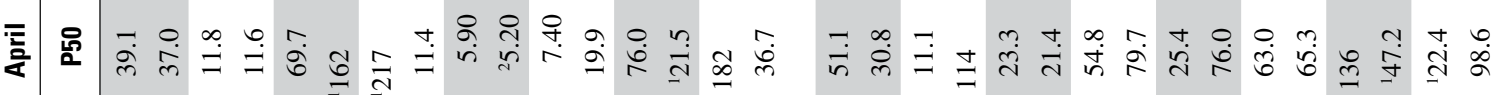

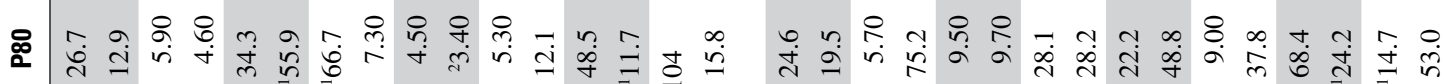
ฐ

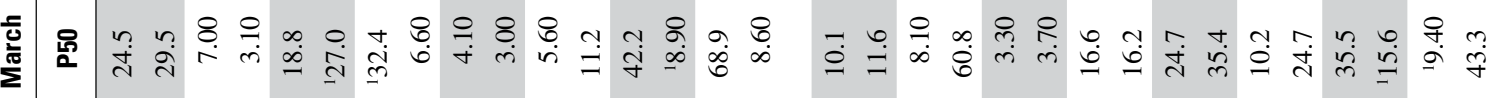

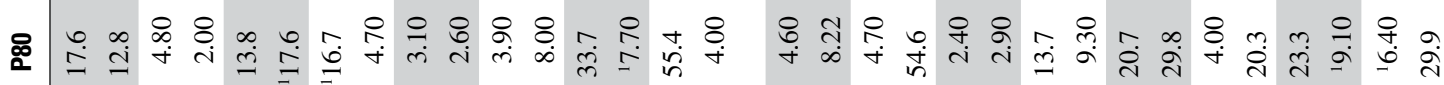

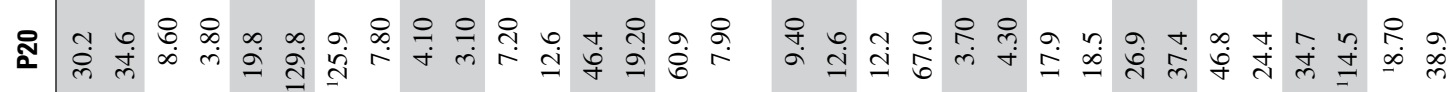

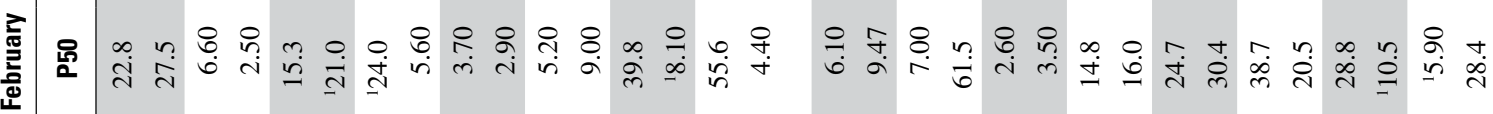

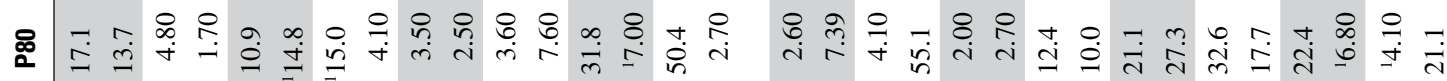




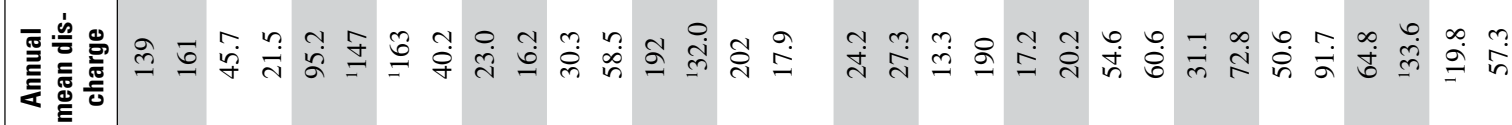

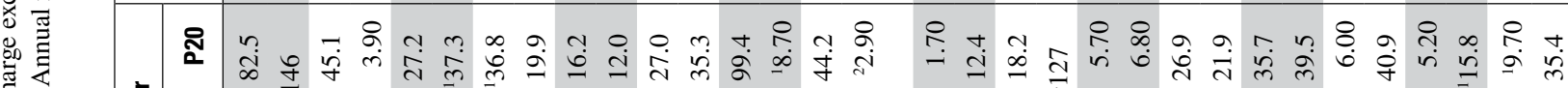
部䓂

대용

然 产

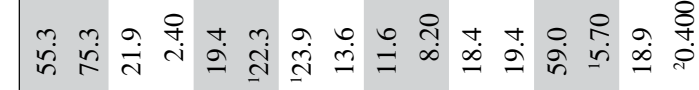

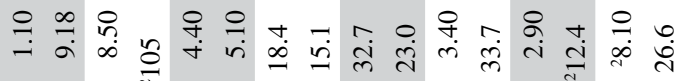

๕̊․ n $\infty$ 웅 $\infty$ a \&్ర

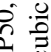
苛.

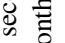
宸

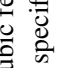

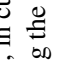
墪高 音 可 政

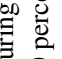
草

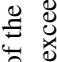

飽品

要 要 言总

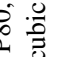
言要 政 항ㅇ

(⿻)

政象

要要要 品 ธิ 产

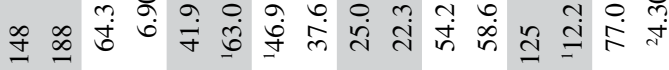

की 0 क के t.

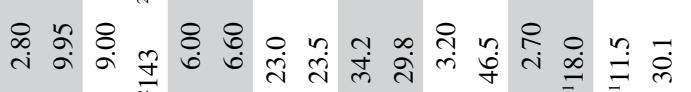
๕. 言通

ธิธ त n

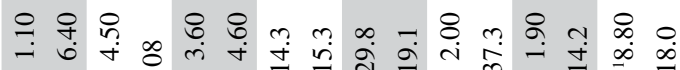
\%ั้ ธิ

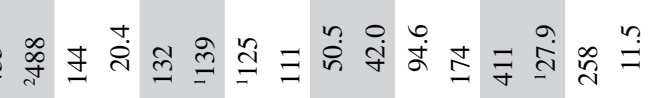

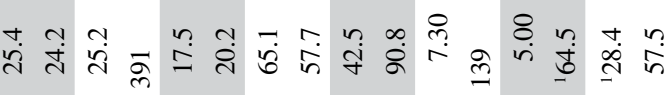

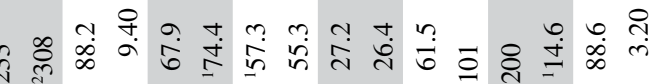

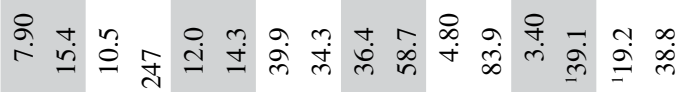

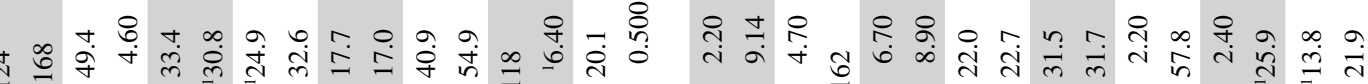
ळ 政

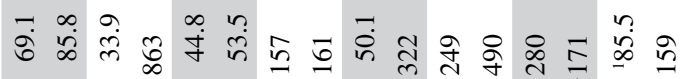

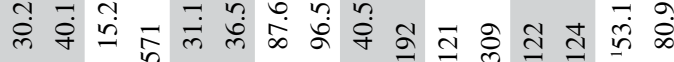

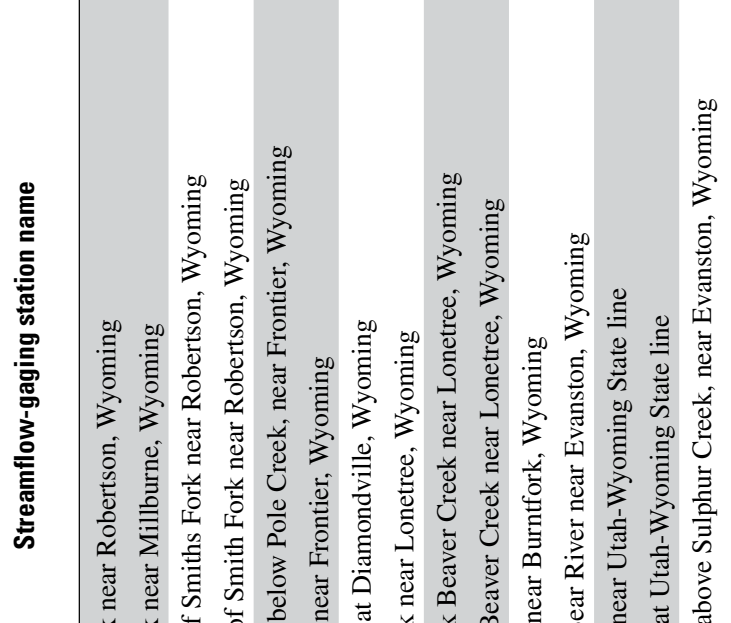

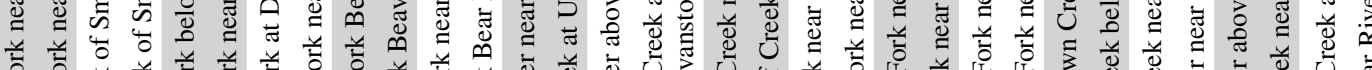

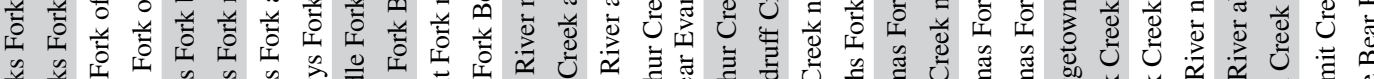

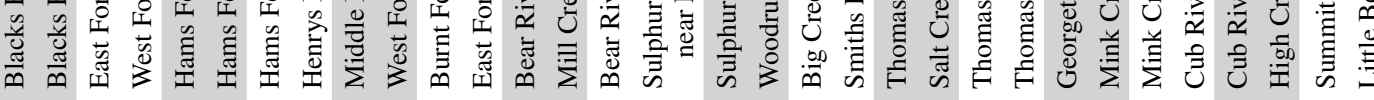

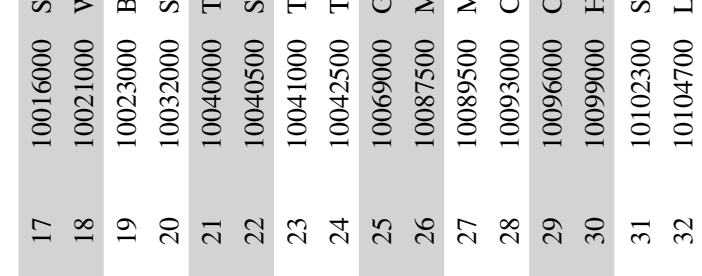




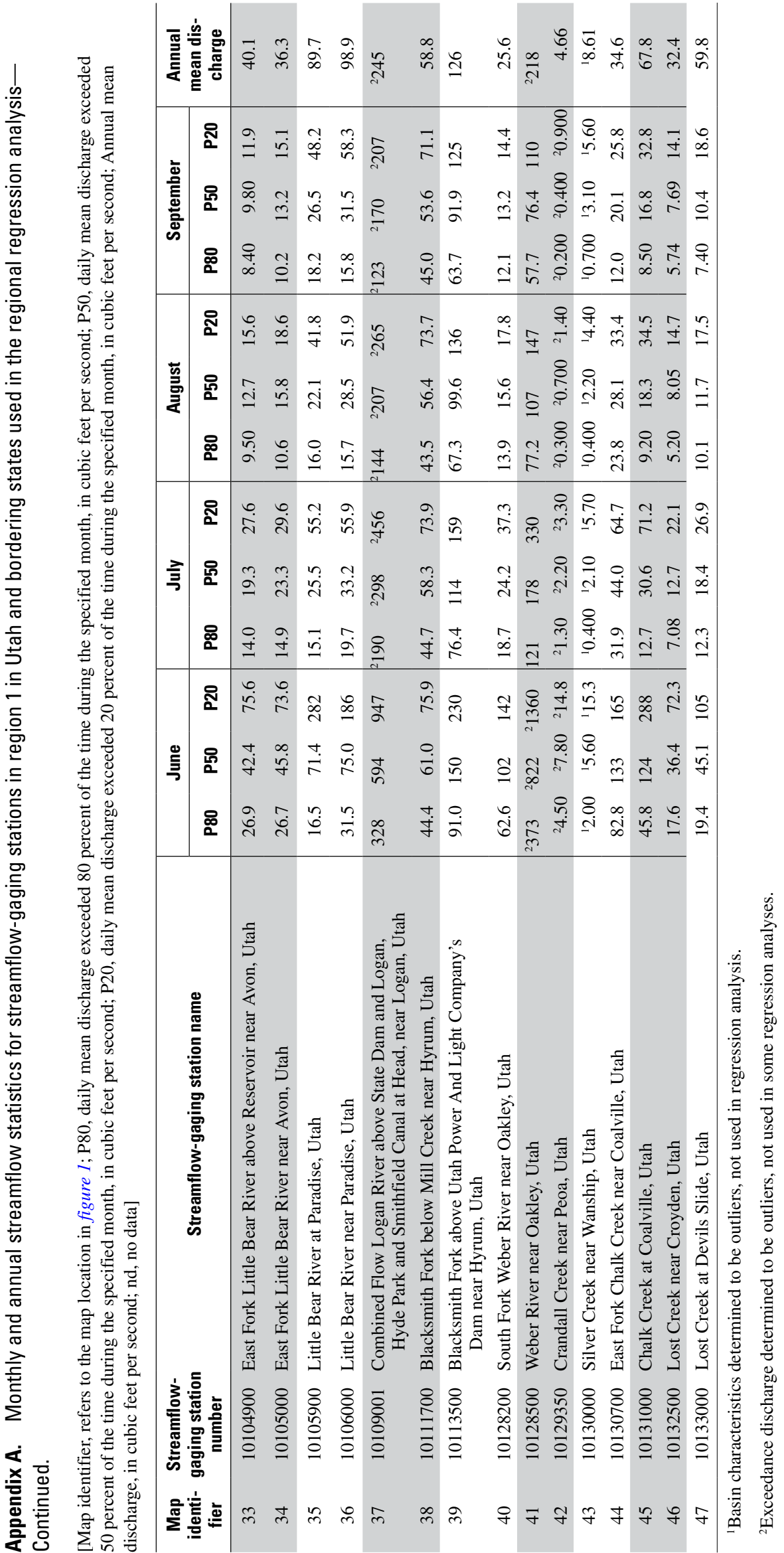




\section{Appendix B.}




\section{递 \\ 这 \\ 品章}

氙

ฐ

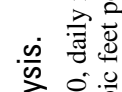

忞

ब。

흥

@

혼

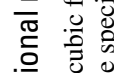

응

至

항

空

西哭

$\stackrel{\infty}{\simeq}$

들 후

응 自焉

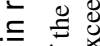

is

흠

要

.

흉

咨

言

离总

흔 등

.

步 중

更 0

उั

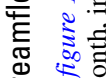

离.

可

志

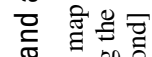

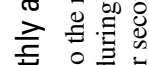

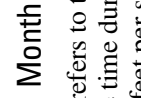

牙.

뜨흘

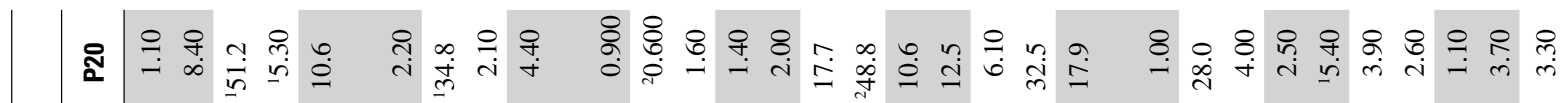
坣

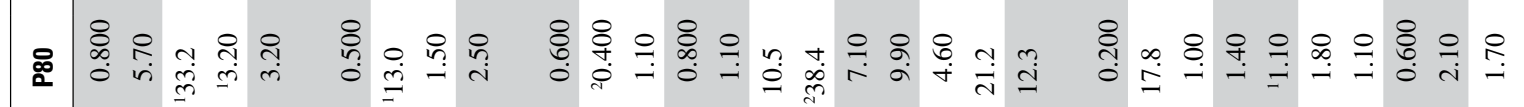
হ

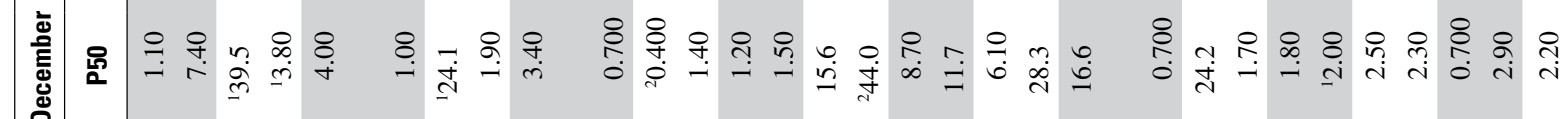

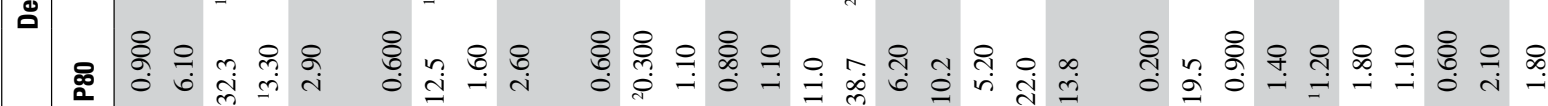

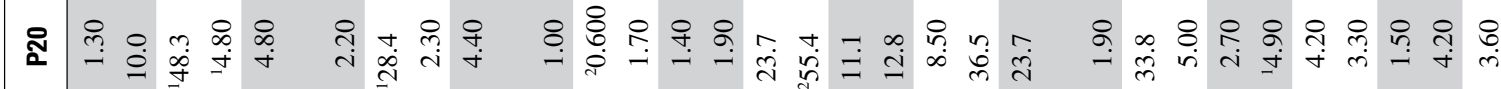

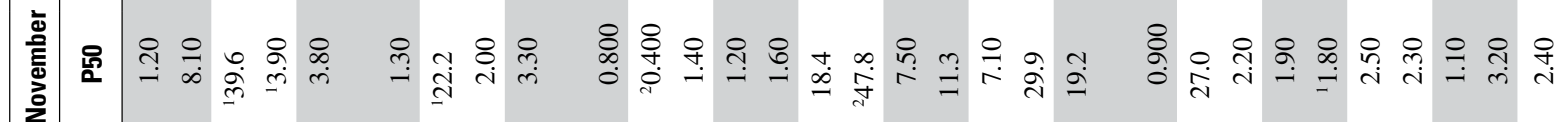

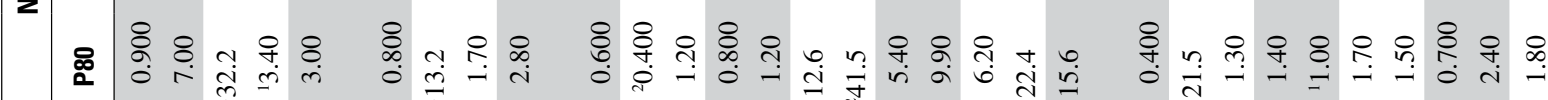

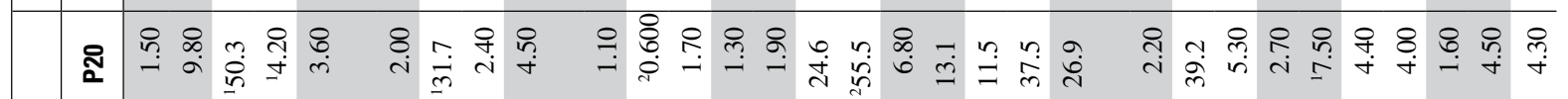
竎

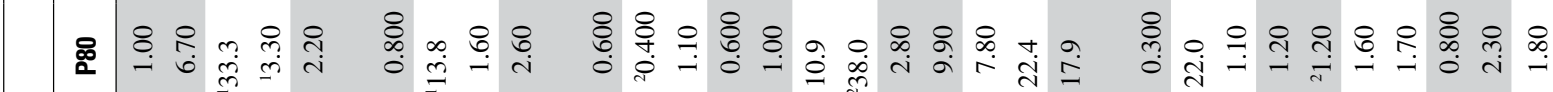
-

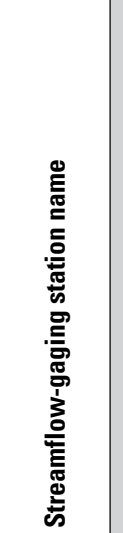

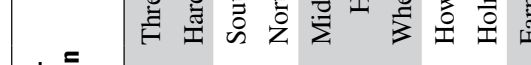

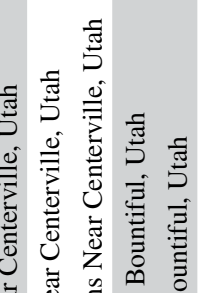

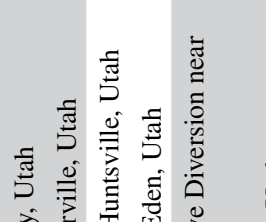

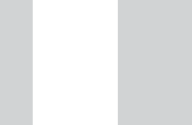

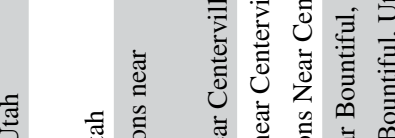

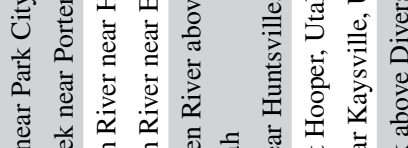

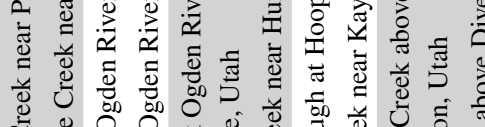

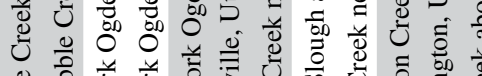

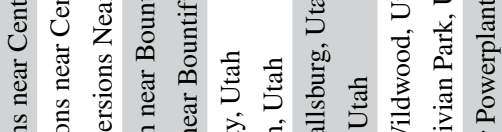

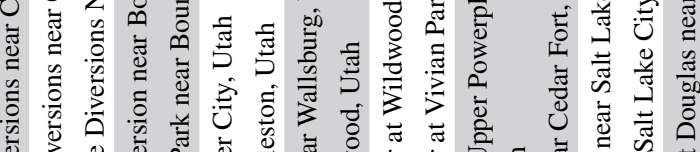

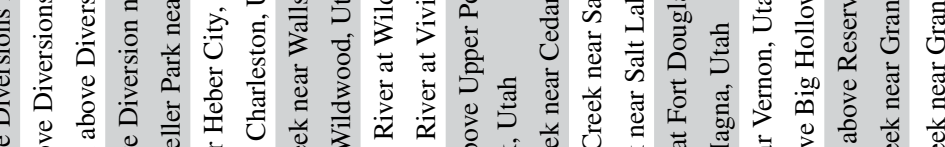

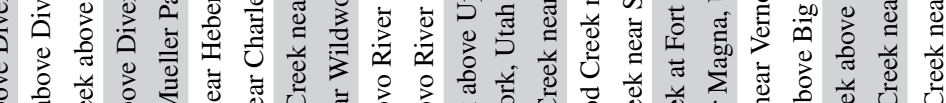

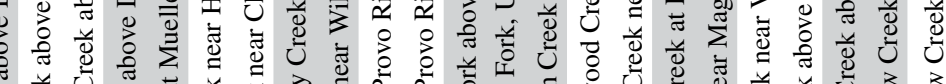

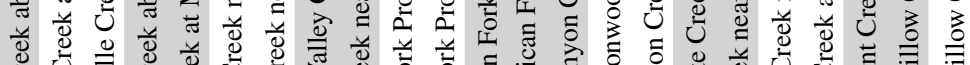

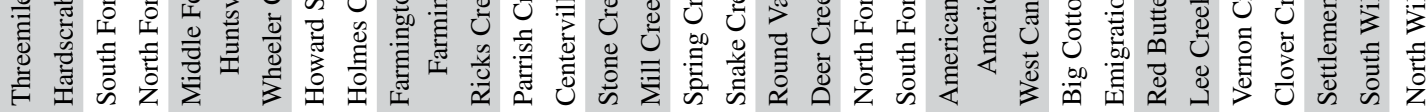

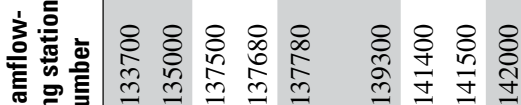
\& 8 \& 8 \& 8 \& 8 \& 8 \& 8 \&

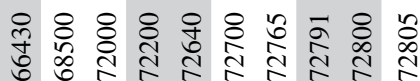

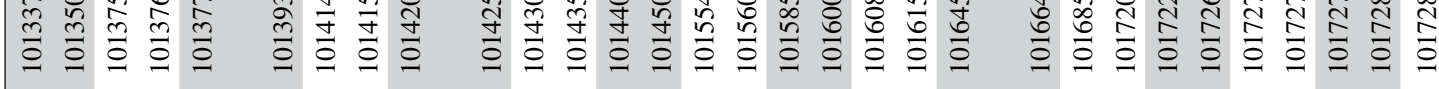

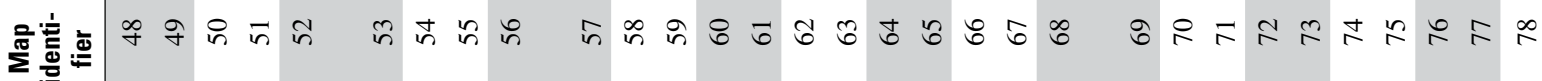




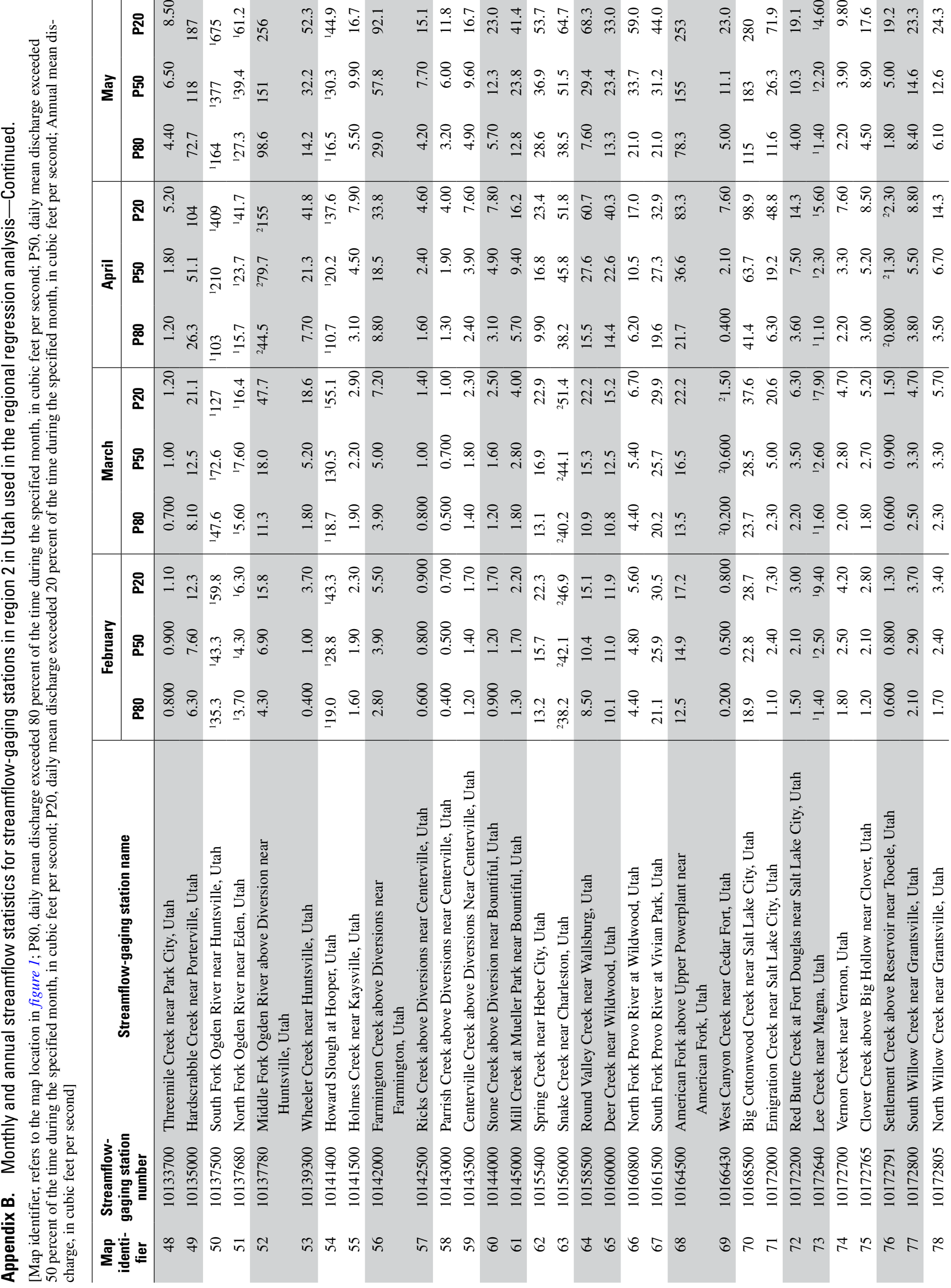




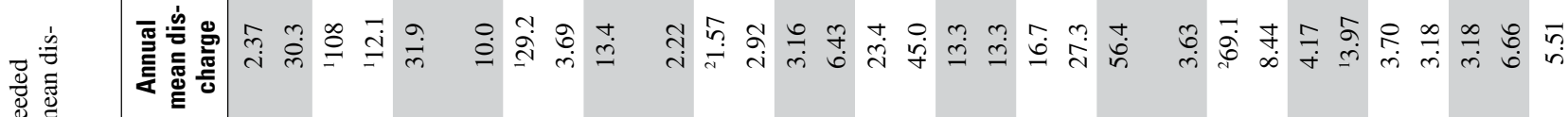

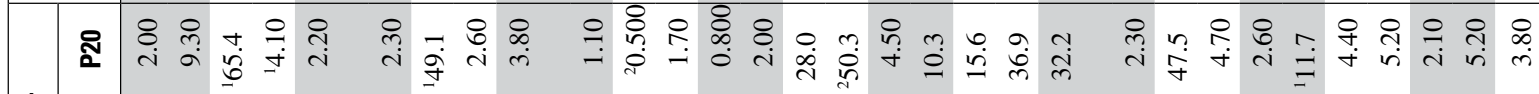

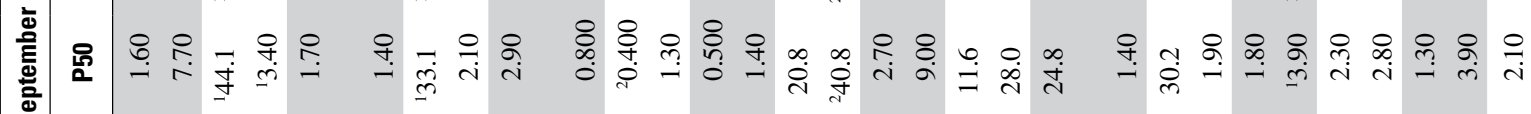

m की 善

永

๓

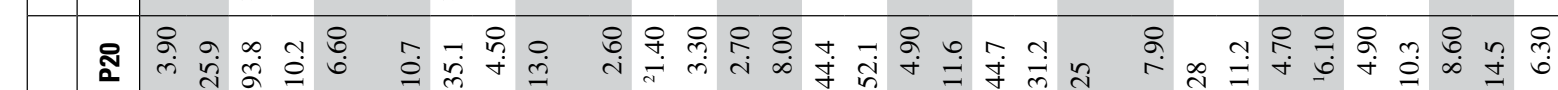
$\Rightarrow$ 西

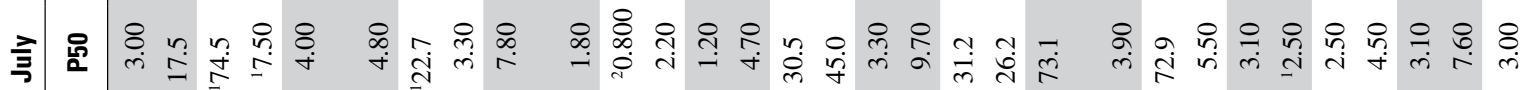

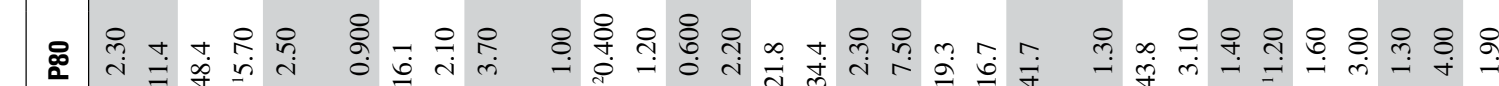
a (

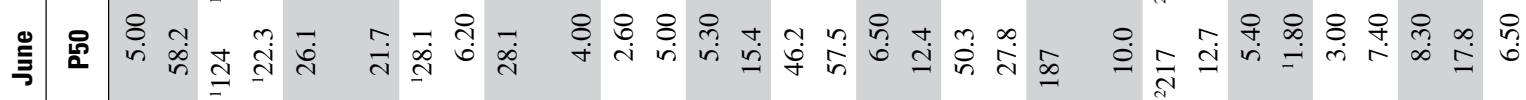

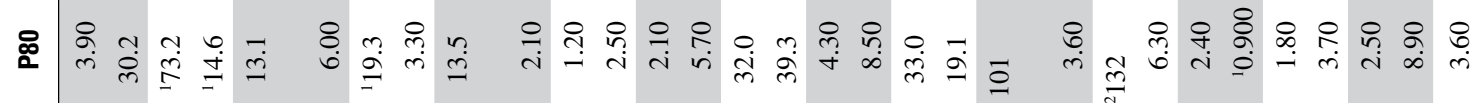


32 Methods for Estimating Monthly and Annual Streamflow Statistics at Ungaged Sites in Utah 


\section{Appendix C.}


胥

两

密莫

莺

露

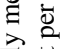

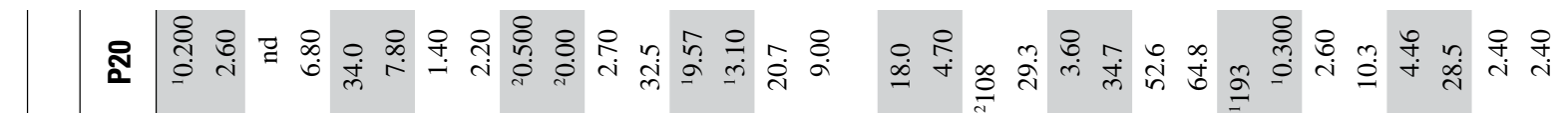

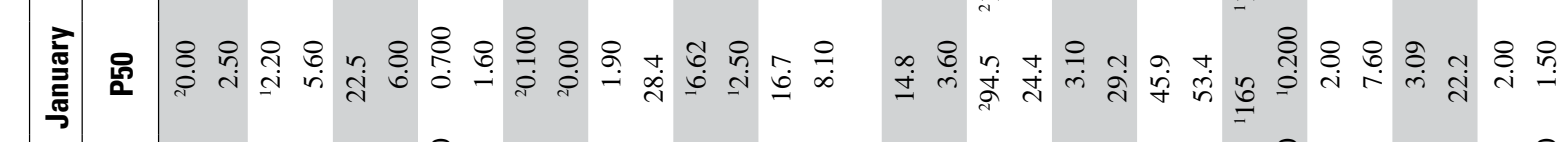
๓

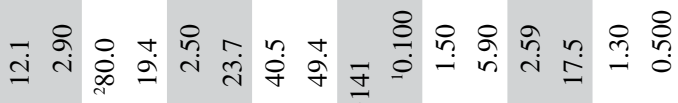

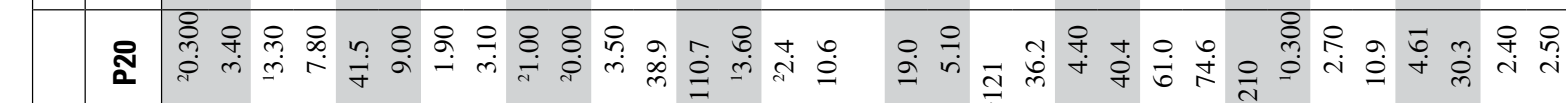

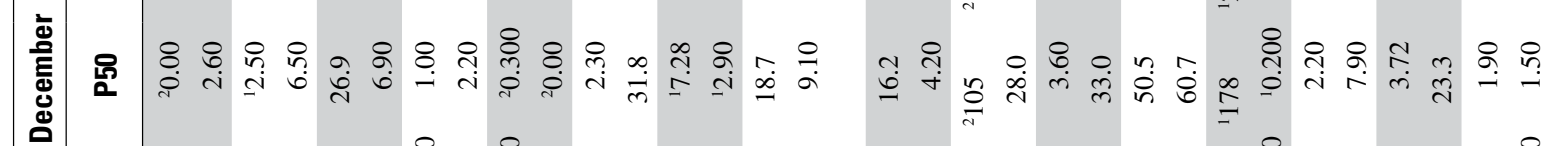
๑

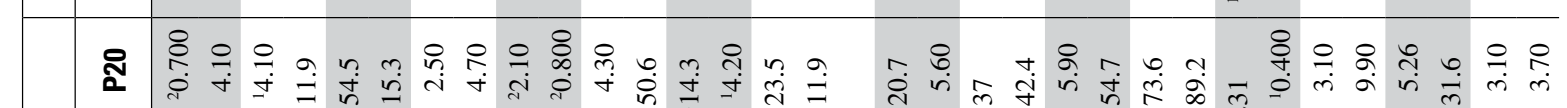
ठำ a on

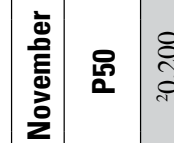
峞,

\& \& \& 8 \&

ब.

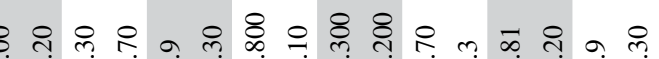

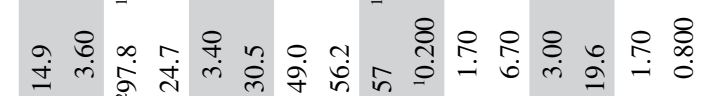

范

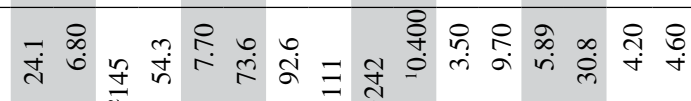

○

๕

일 అூ

远

ชิ

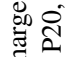

总

政

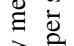

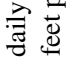

$\infty: \frac{0}{0}$

$\because 0$

咅

事

觉

हुँ

응

诘 :

春宽

离品

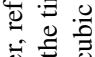

ن

密㐫

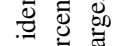

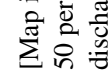
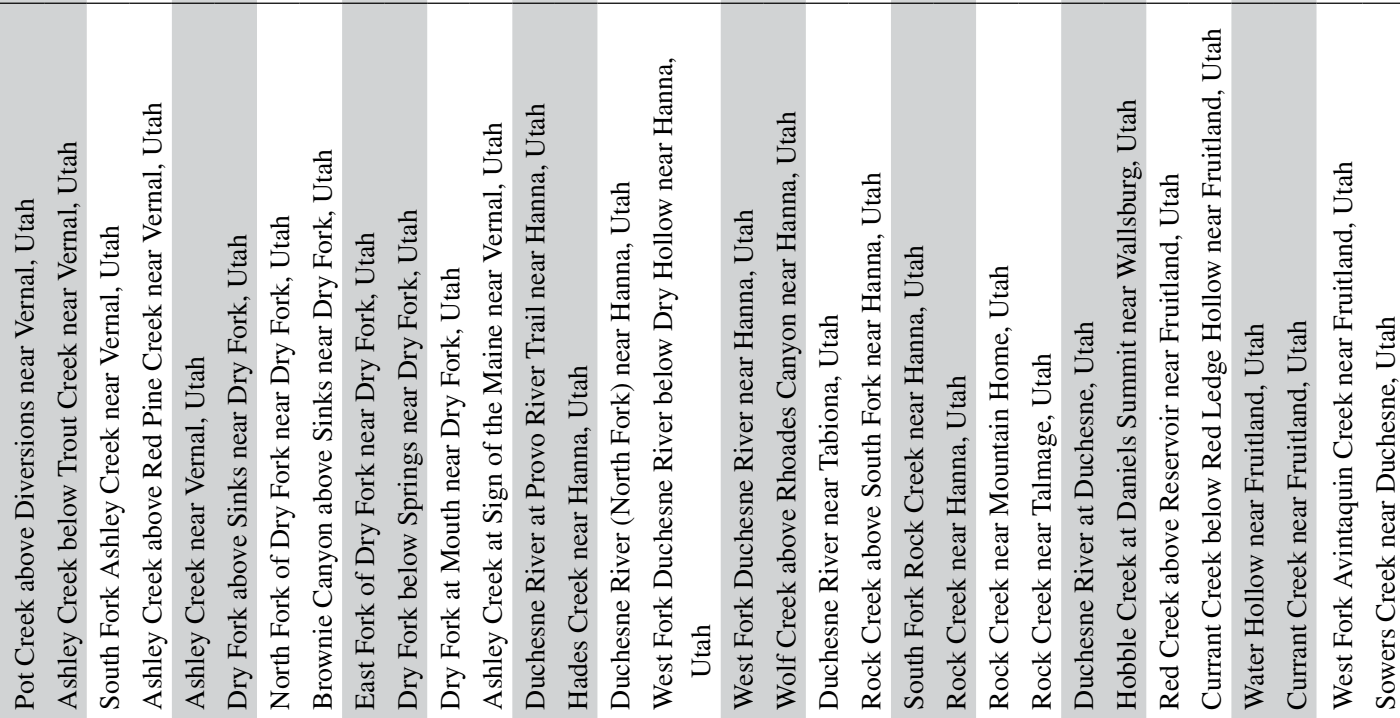

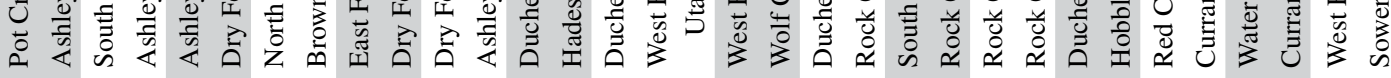

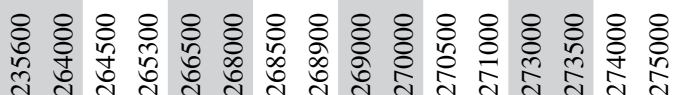

\& \& \& 4 4 i 40 i

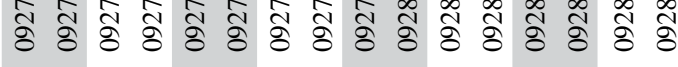

尺 வ 


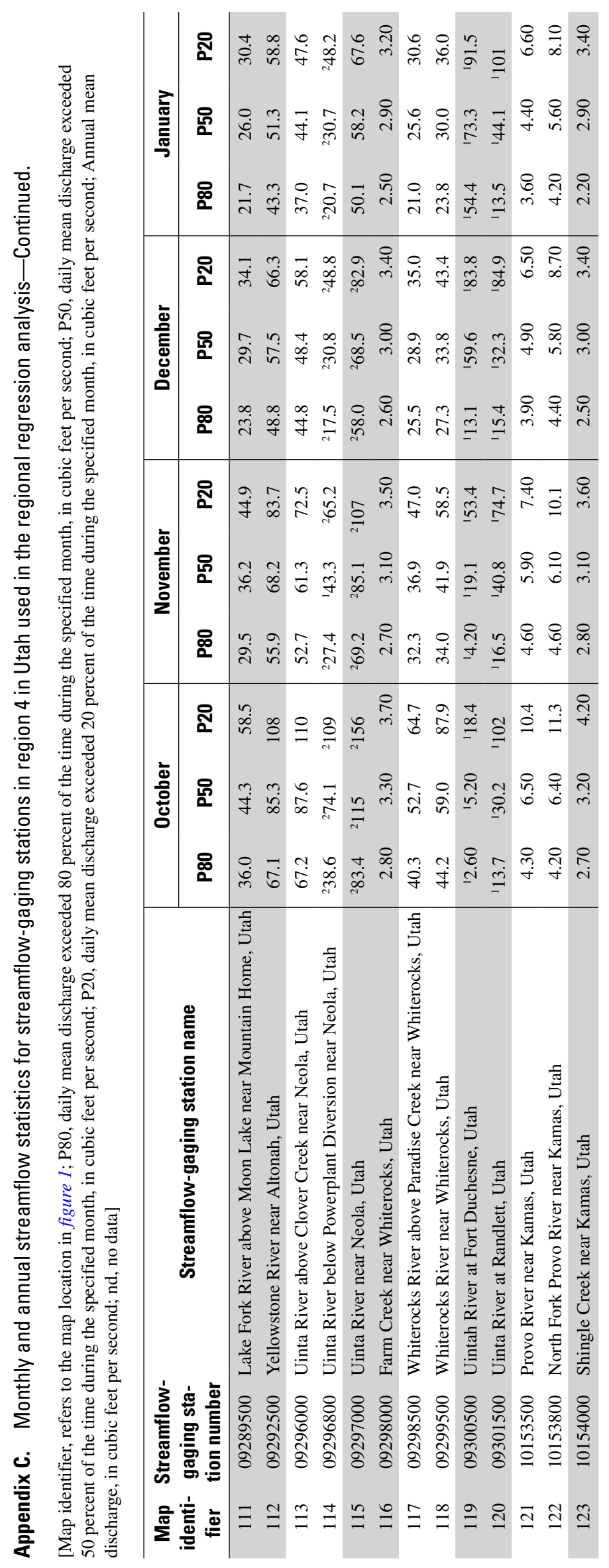




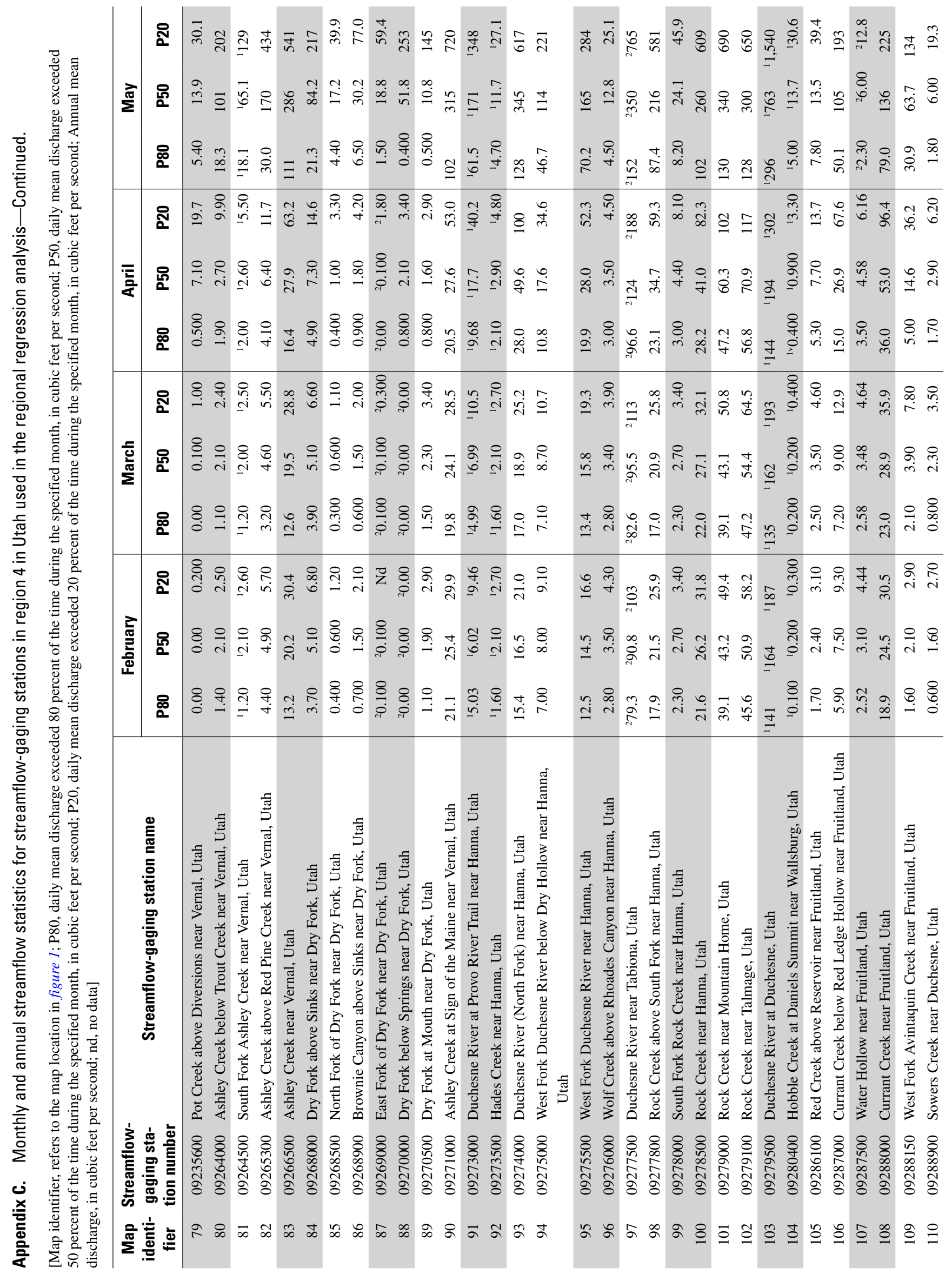




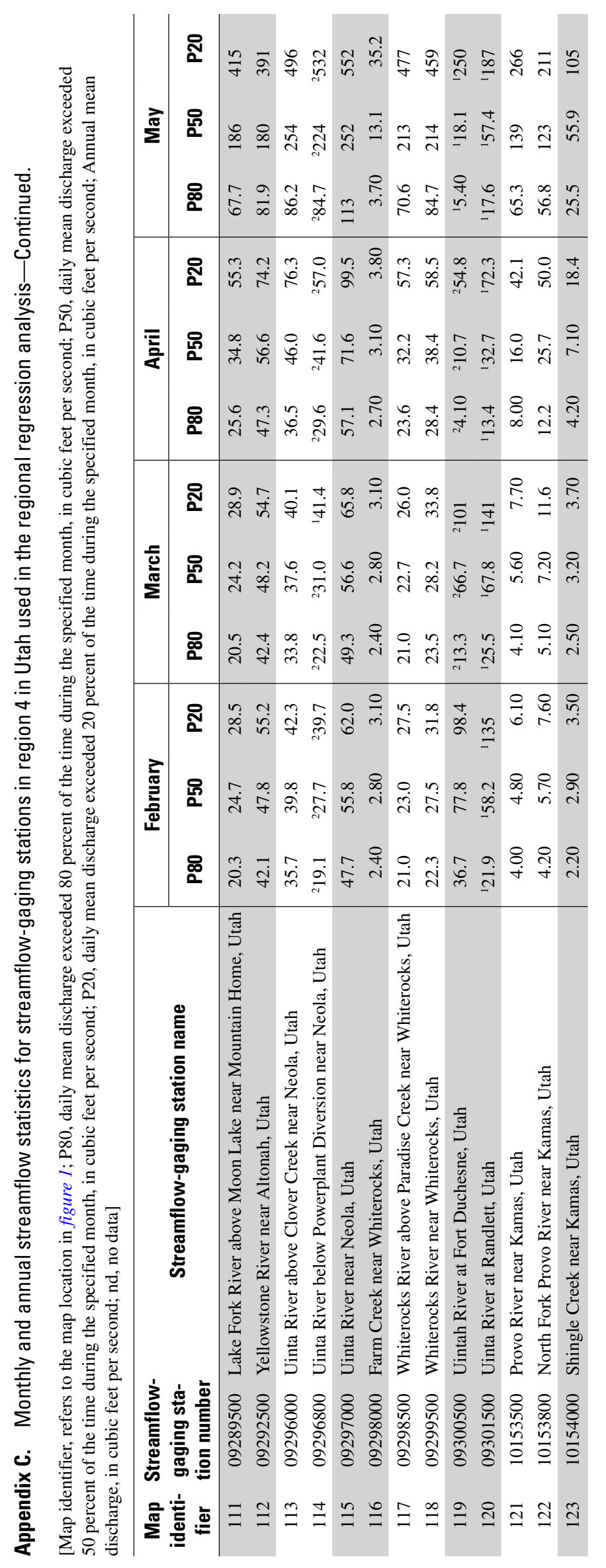


ष्ष

일

㩆安

䆣要

空

$\ddot{*}$.

응

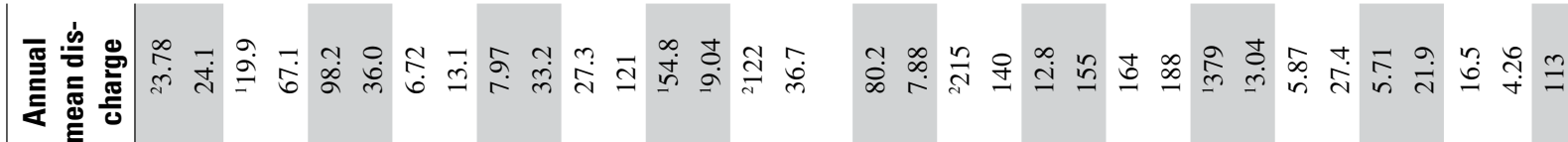

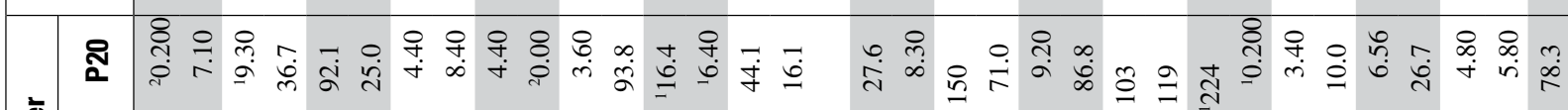

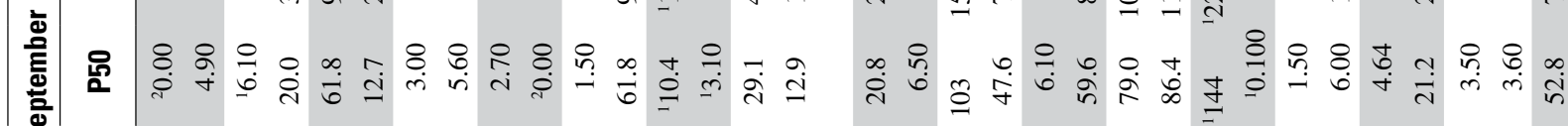

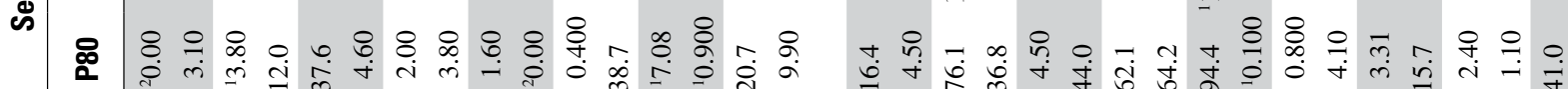
হิ 岛

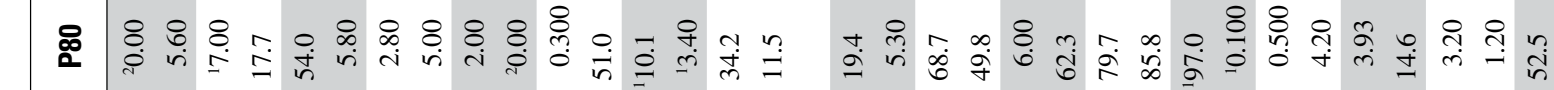
ฉิ

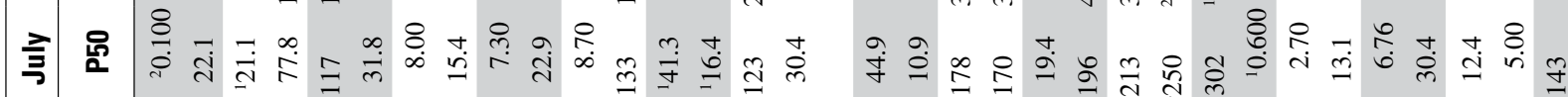
ळ

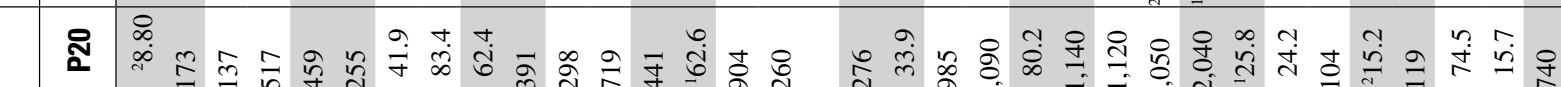
$000+$ o

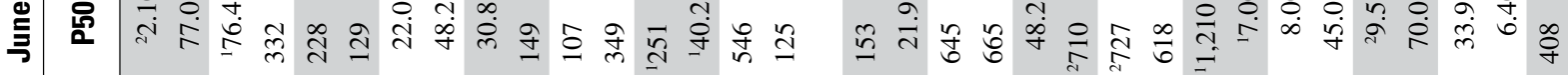
ळ

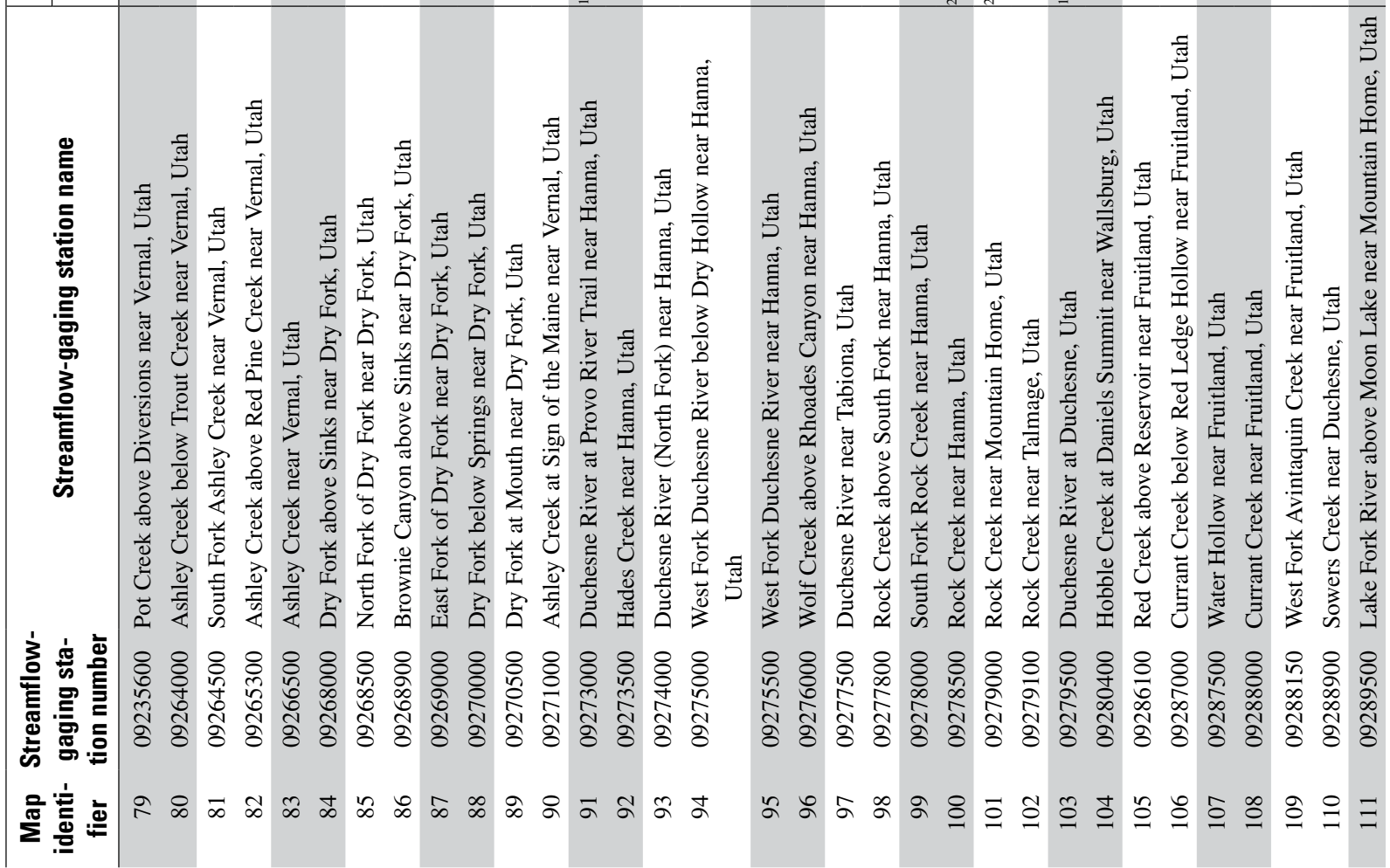




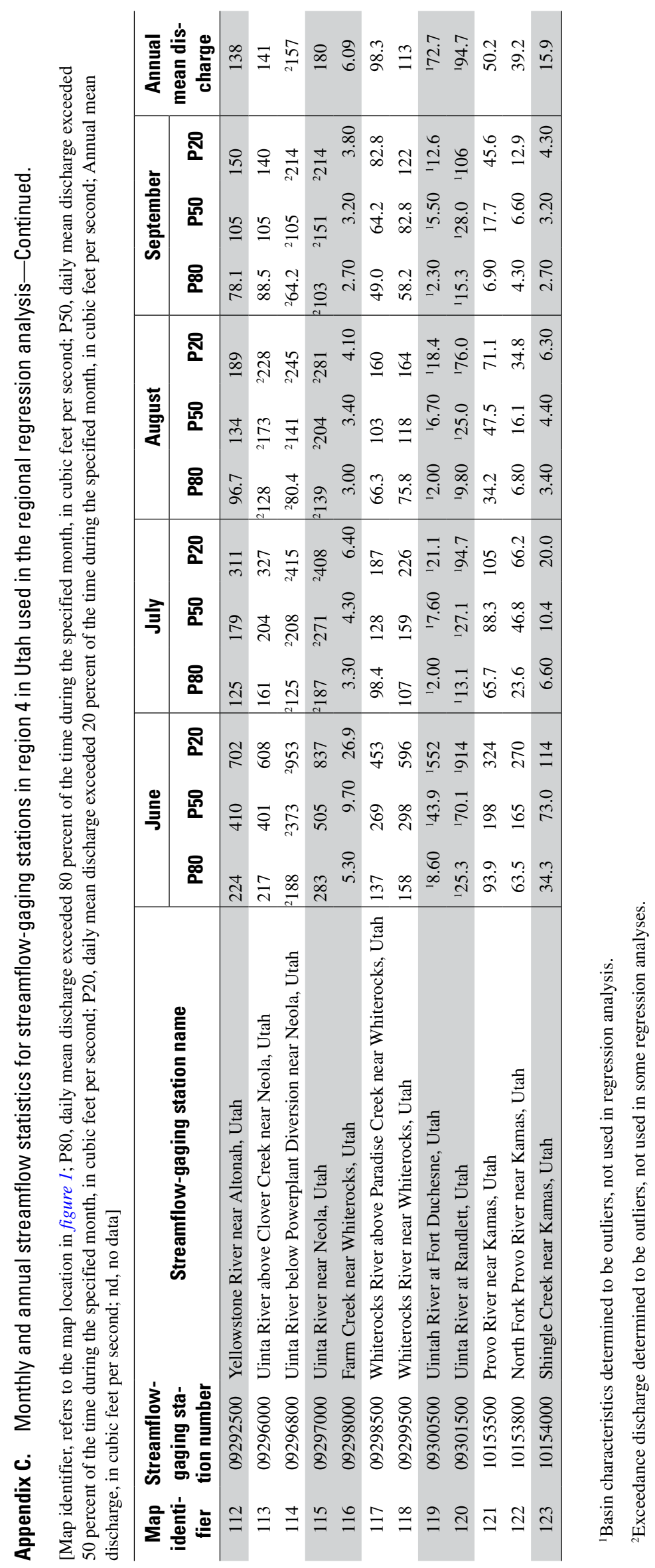


Appendix D. 


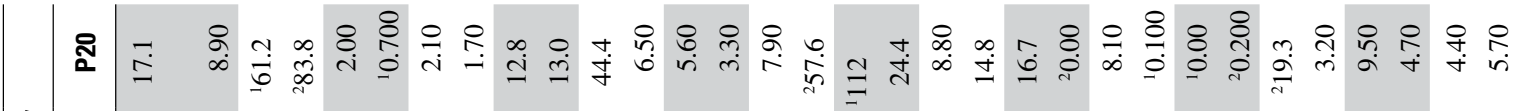

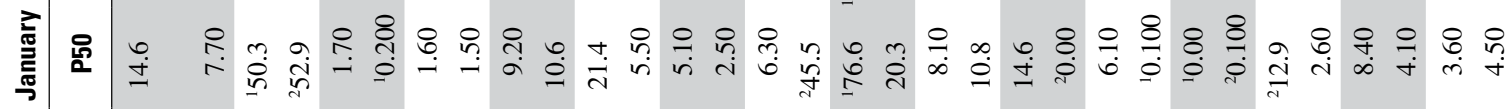
๓

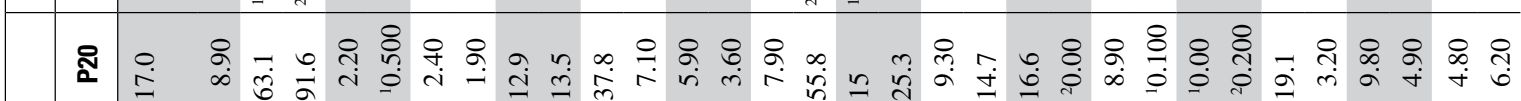

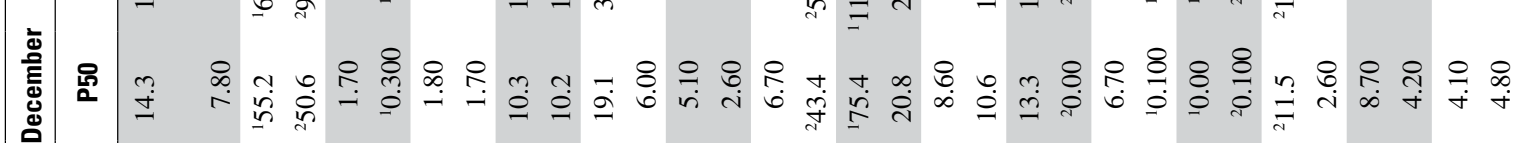

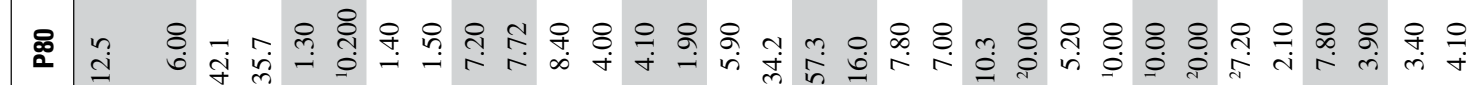

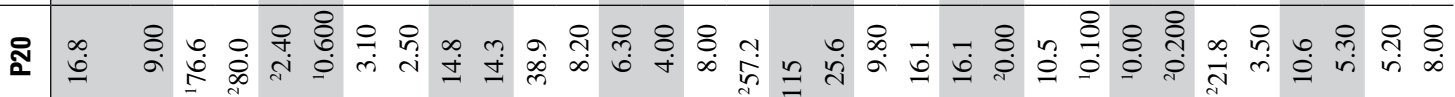

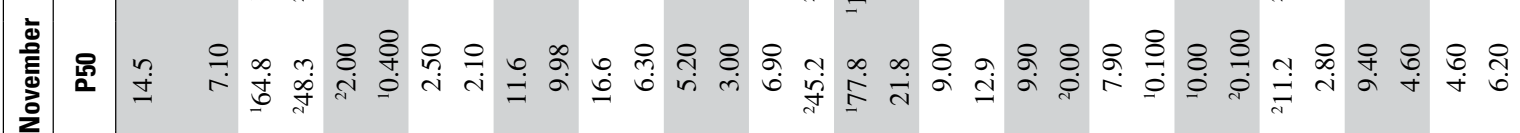

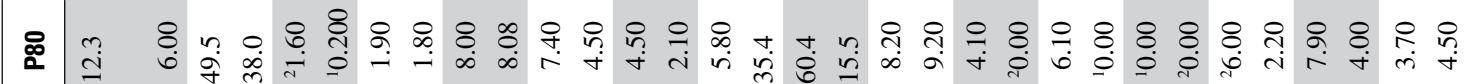
言 递 ते

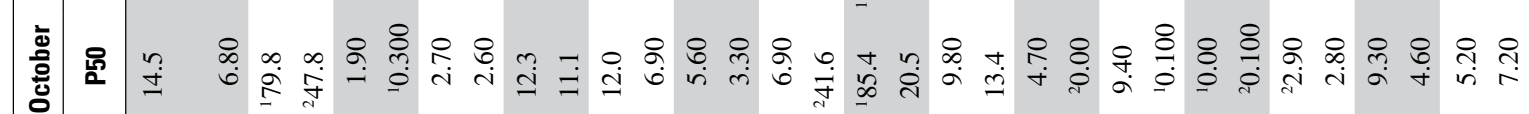

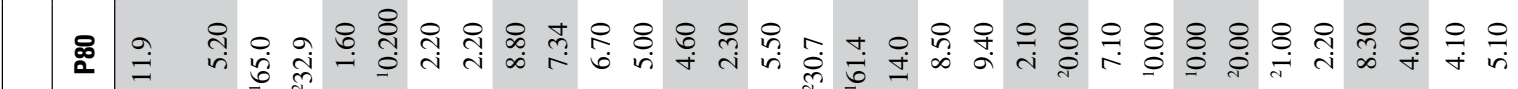

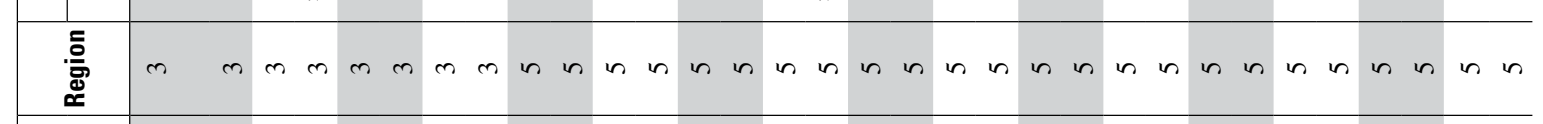
要 0 竞. 要, in $\simeq$ 요 施 要 $\ddot{\theta}$

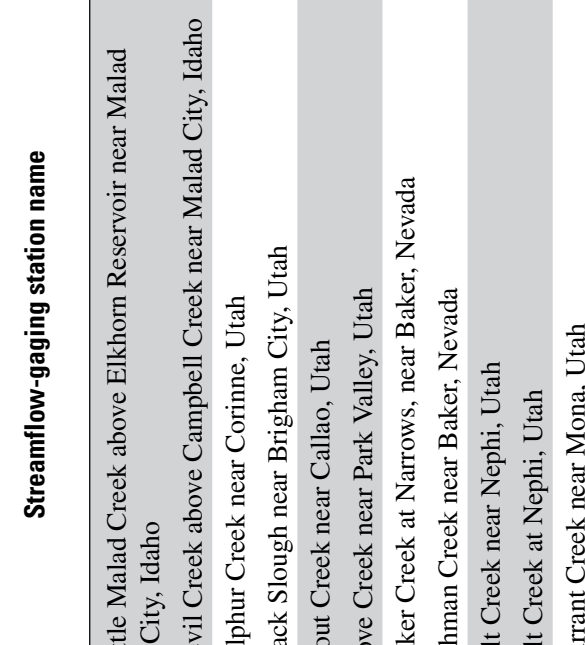

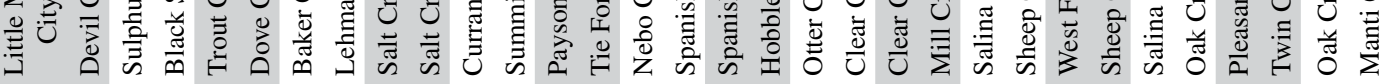

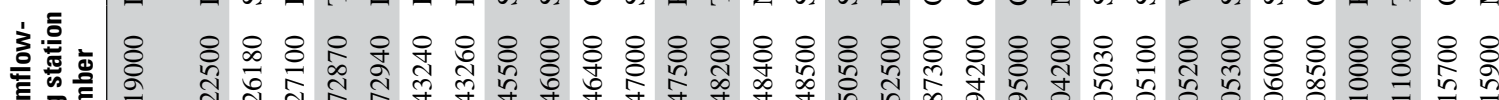
运 造 总言言

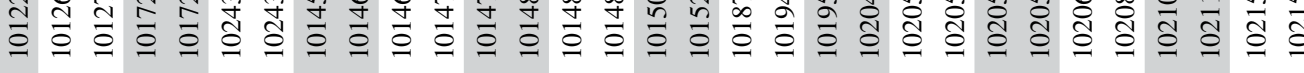

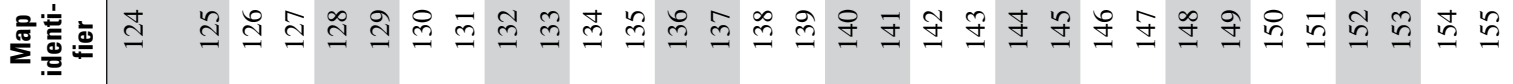




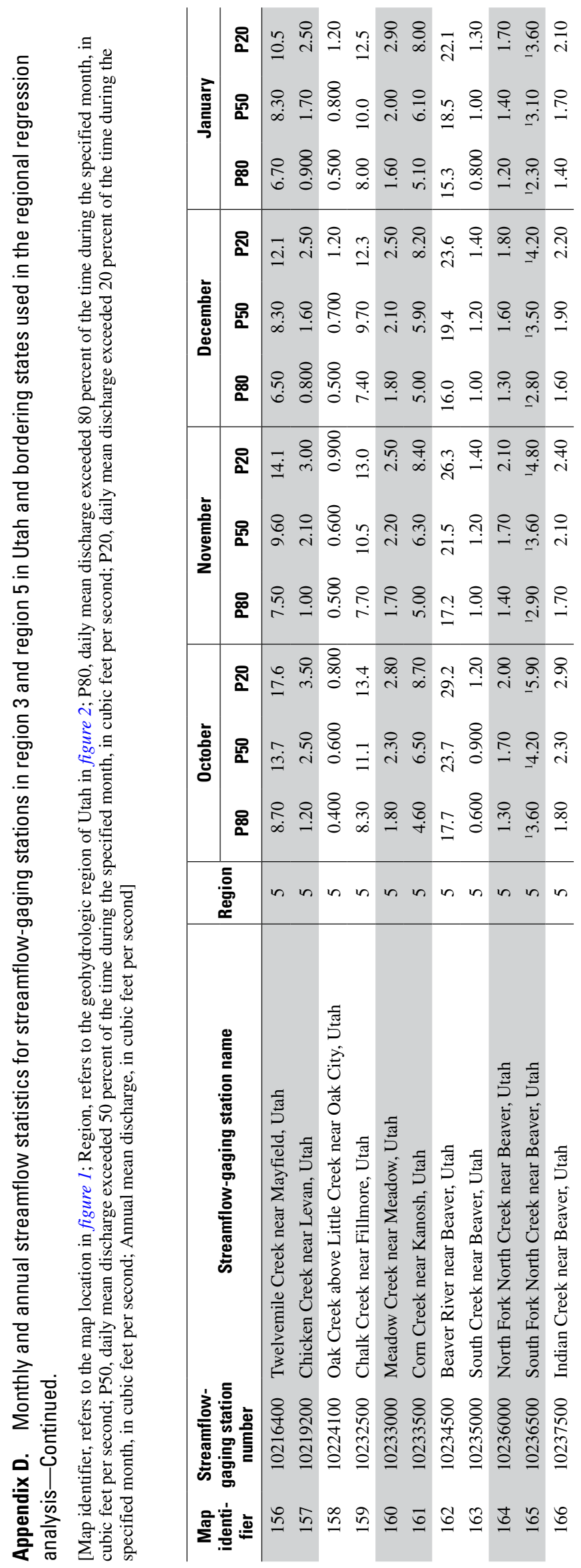




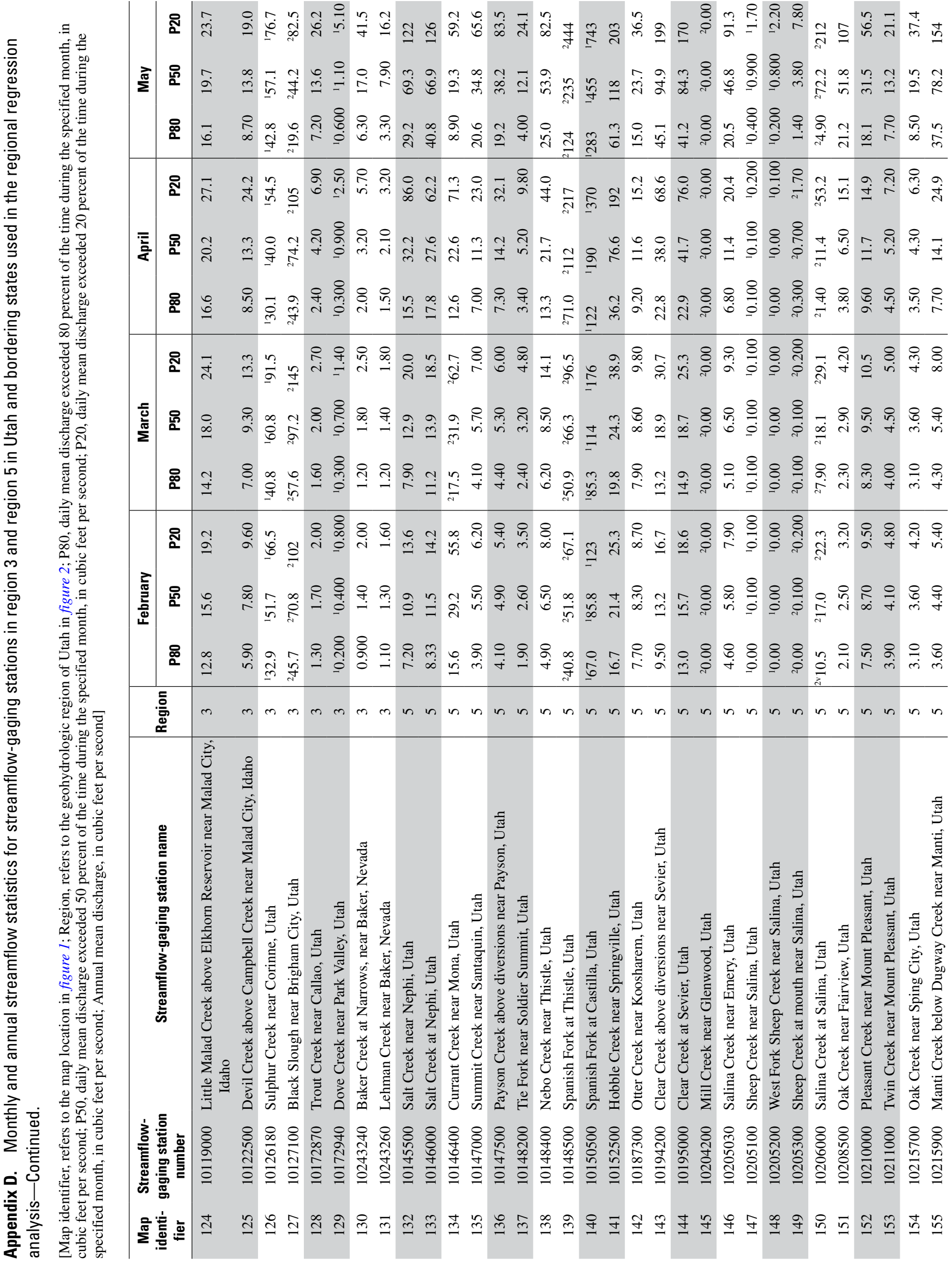




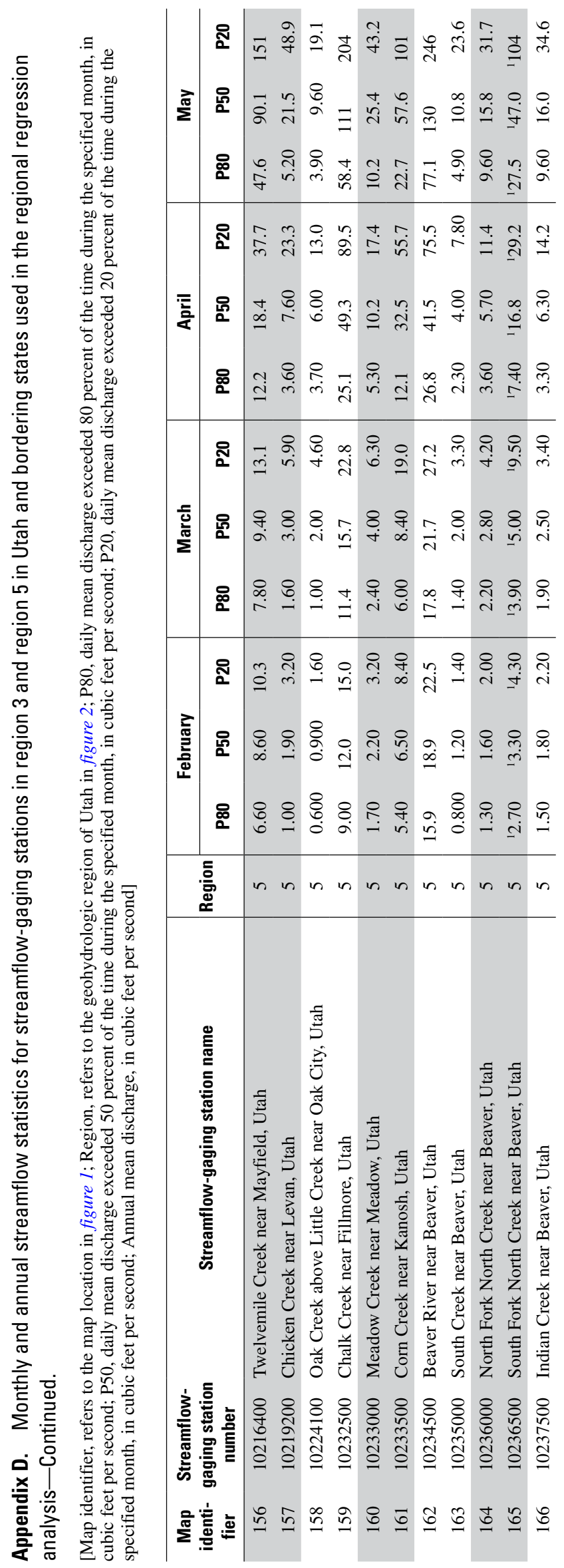




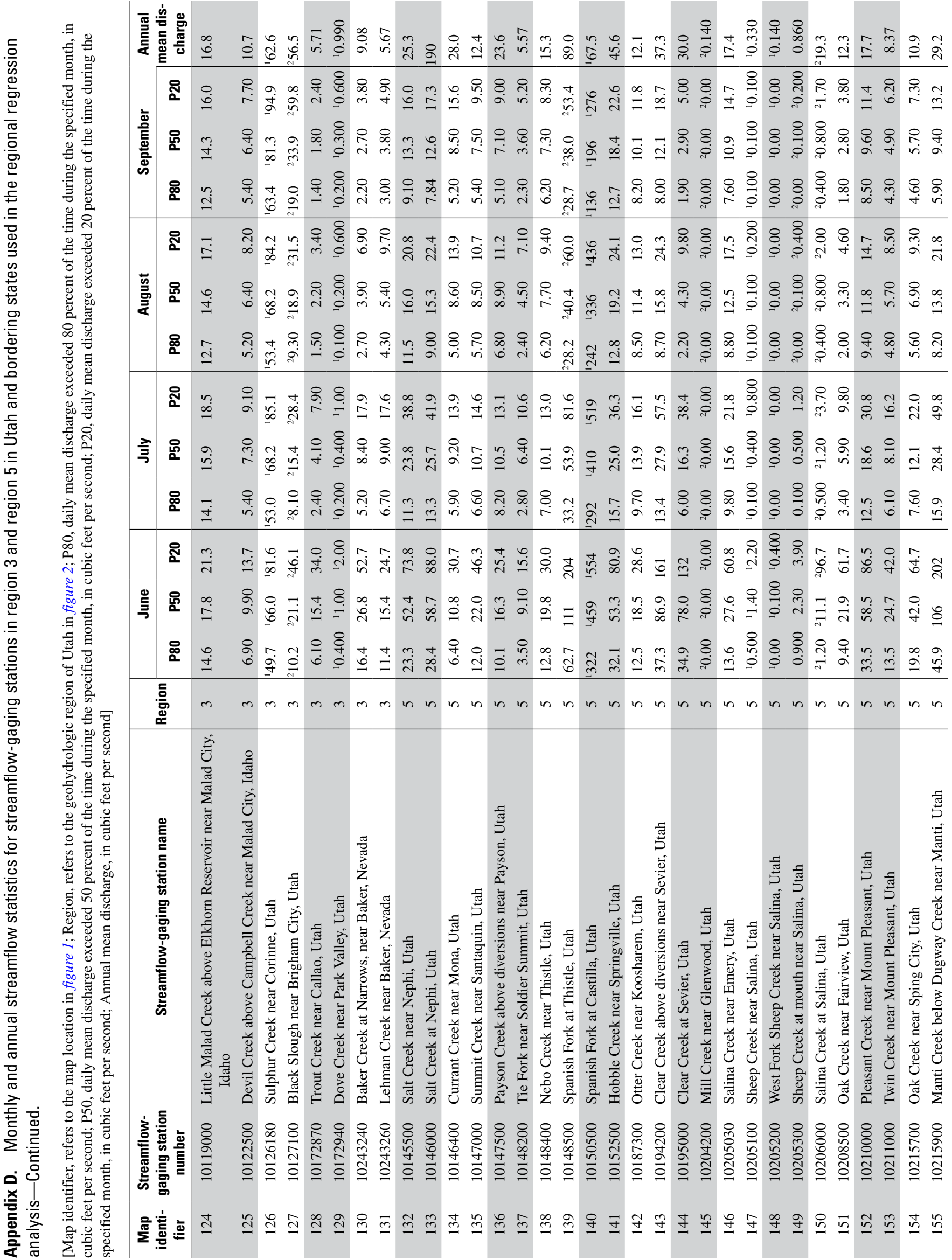




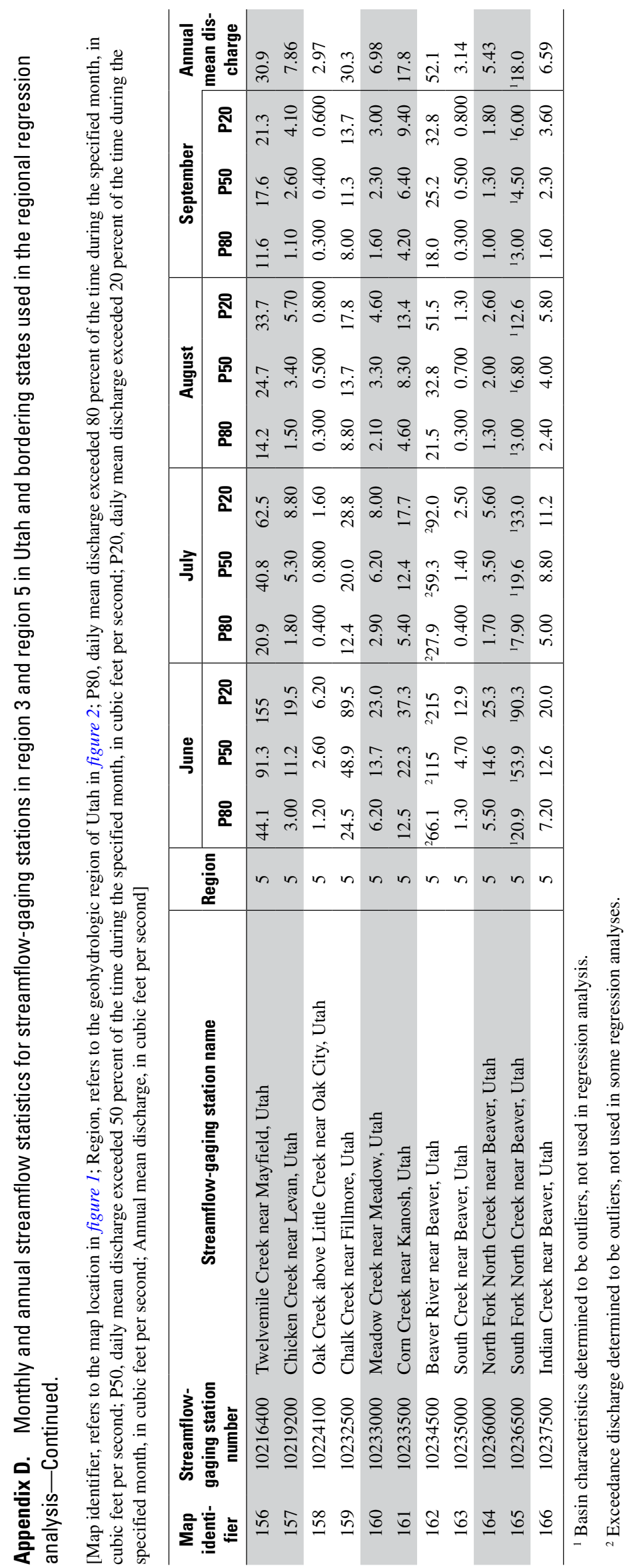




\section{Appendix E.}




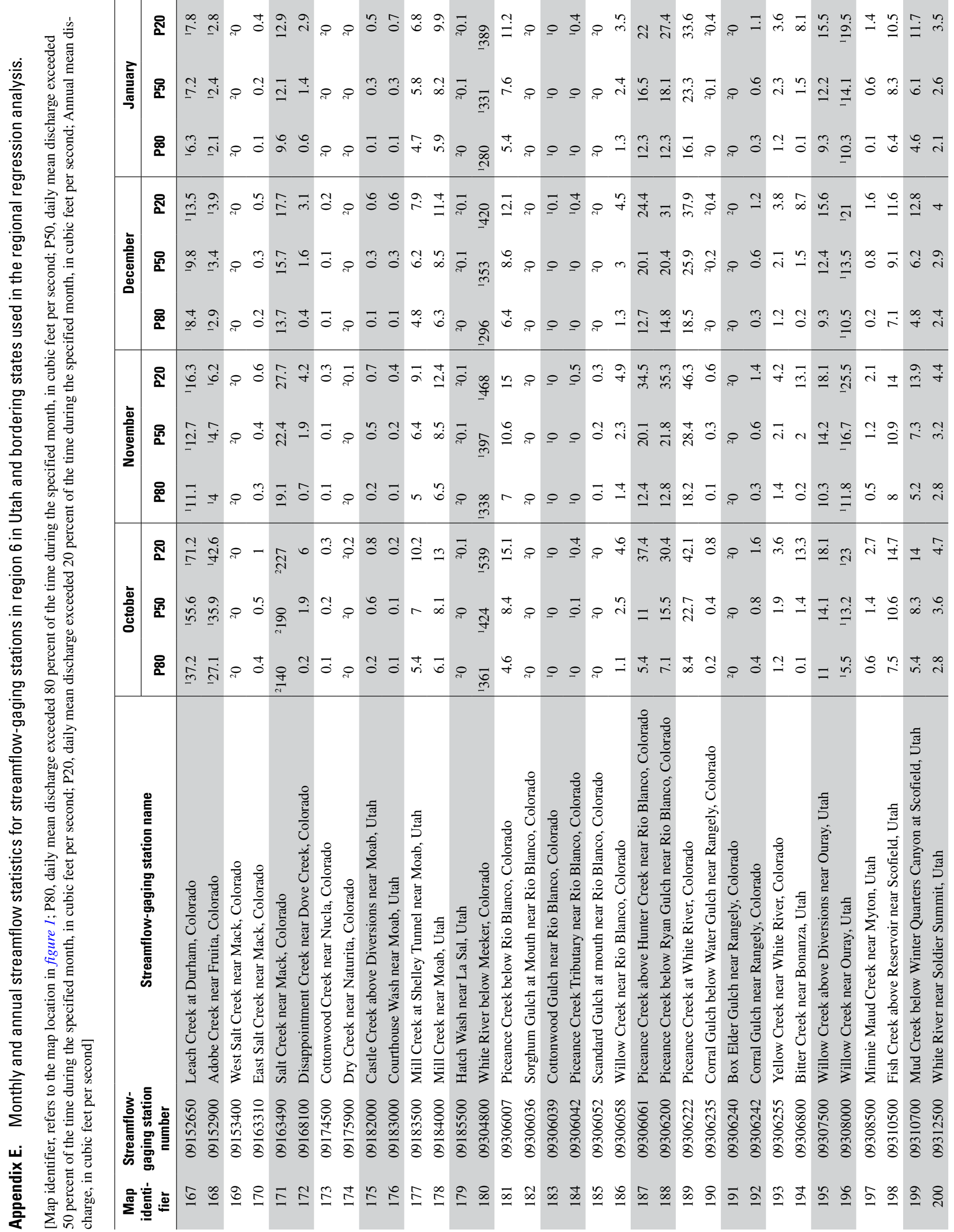




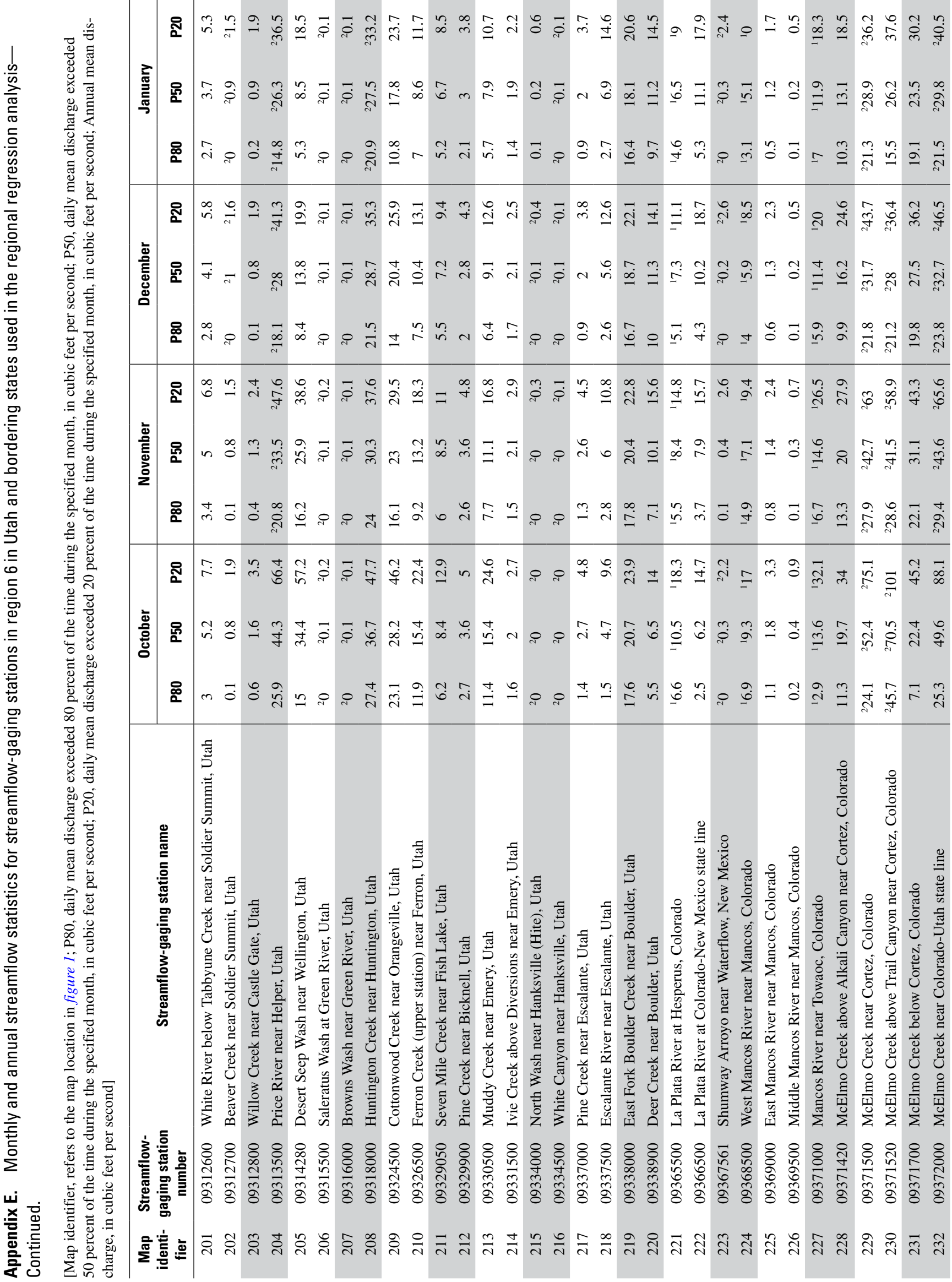









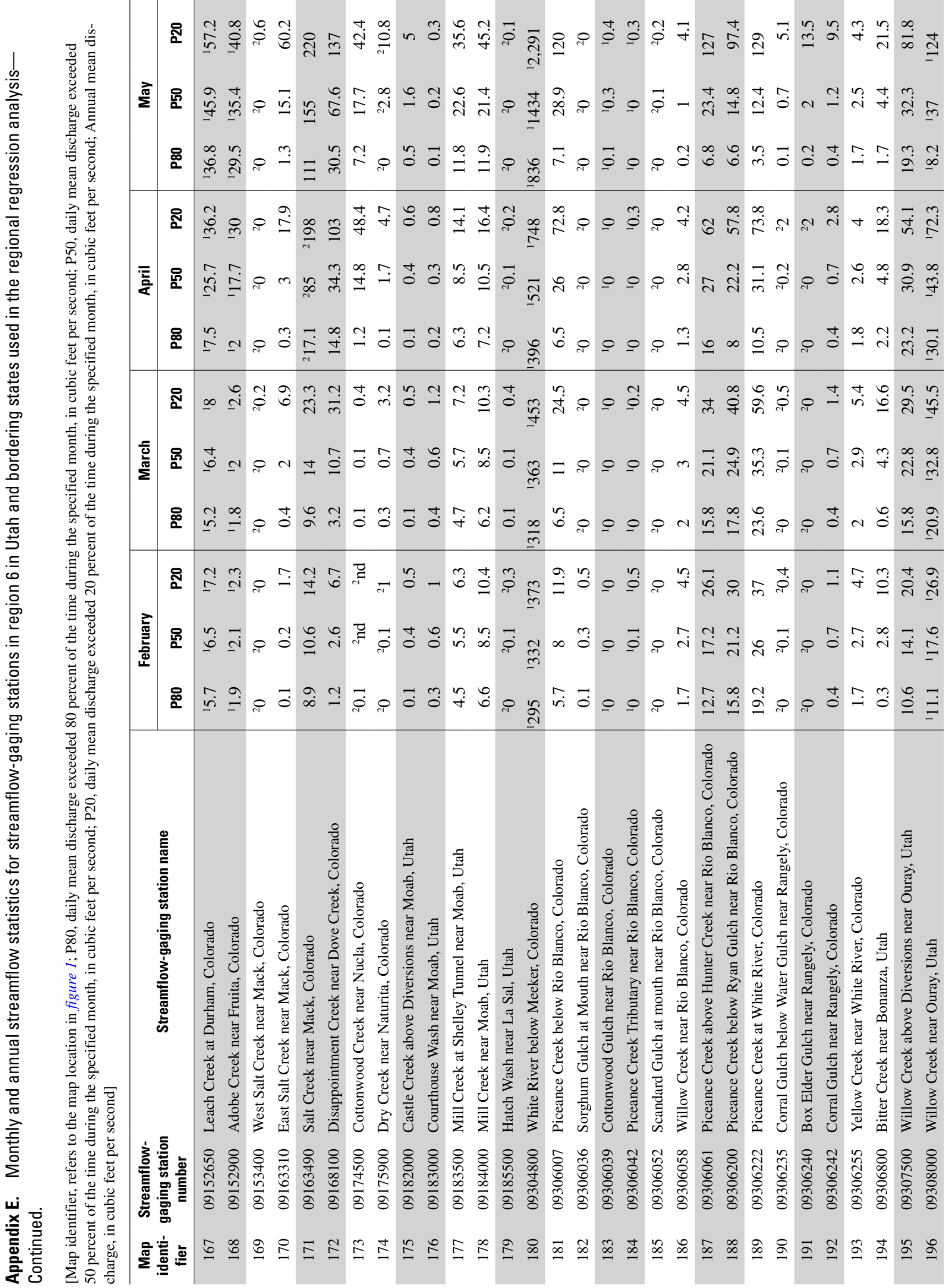




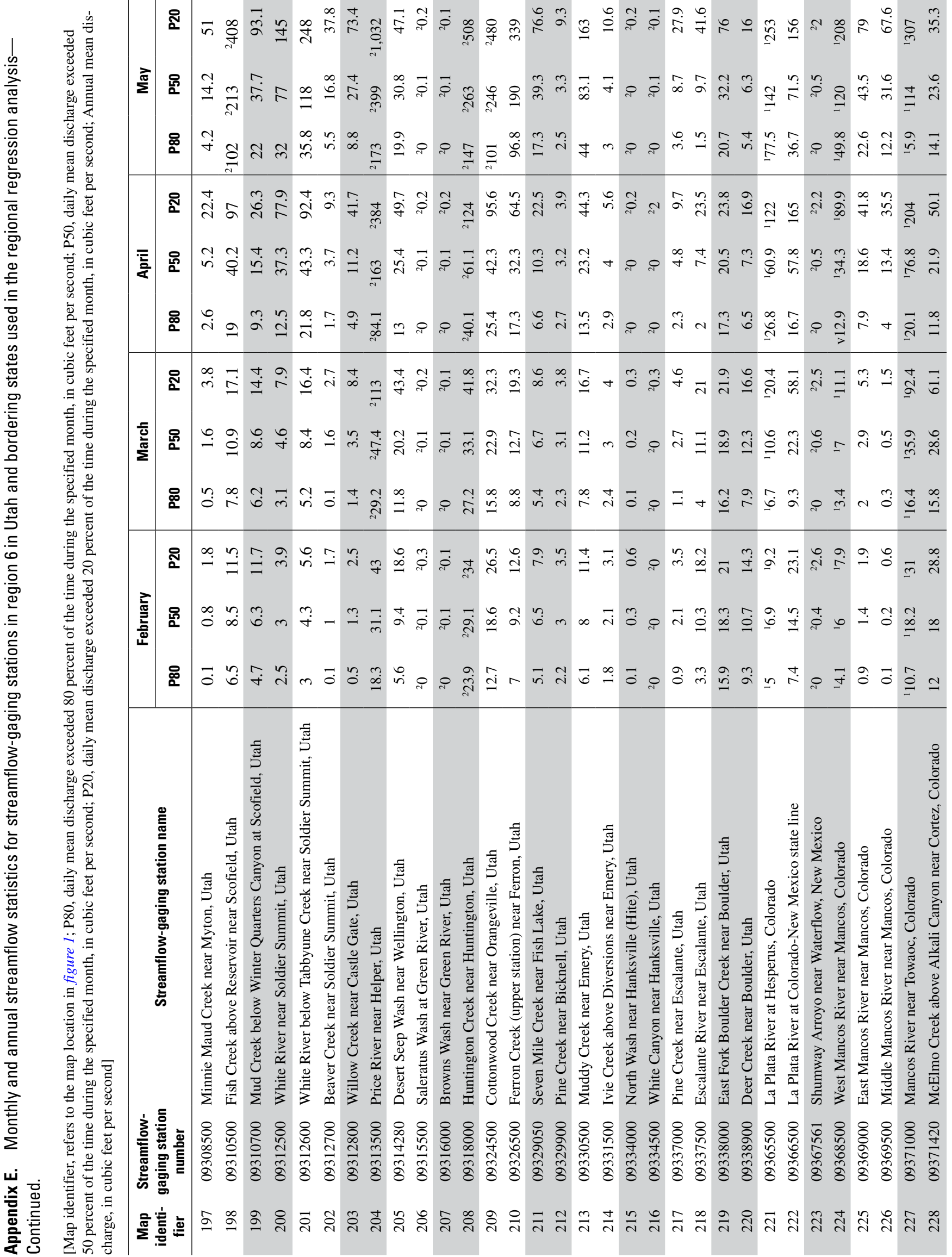




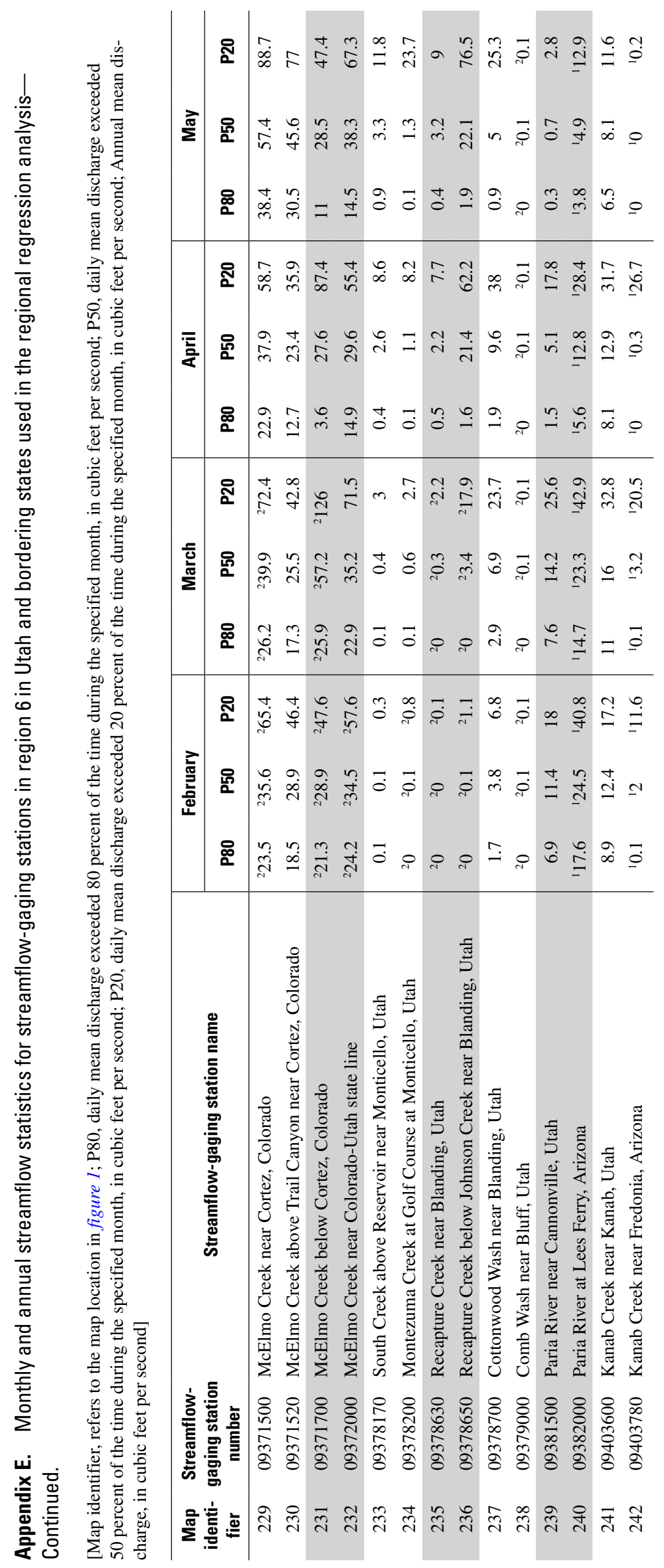


|

줄

兽走

矛

हี

可

증

ถุํํㄹ

$\ddot{\vec{u} . \Xi}$

ठํํ

远

过

के

$\stackrel{\circ}{\Xi}$

혈

离

कू

윰

品造

용

署

낭

离品

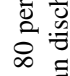

可

気 증

密

氙

跑

岕

츨

定:

$\ddot{\sim} . \Xi$

密

$\Xi$

. ํㅠㄹ

음

芵

氙

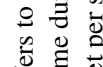

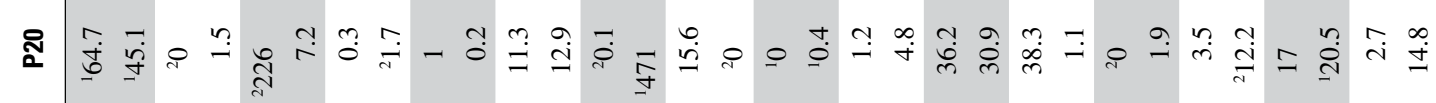

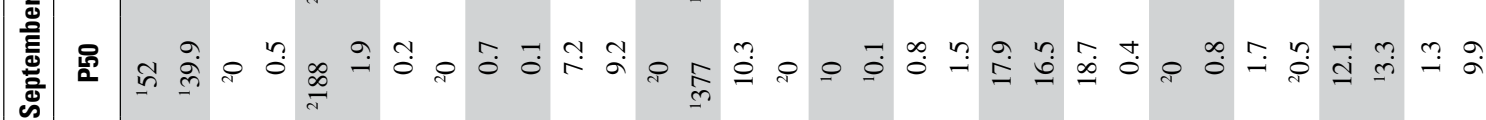

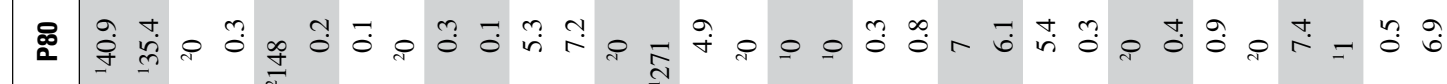

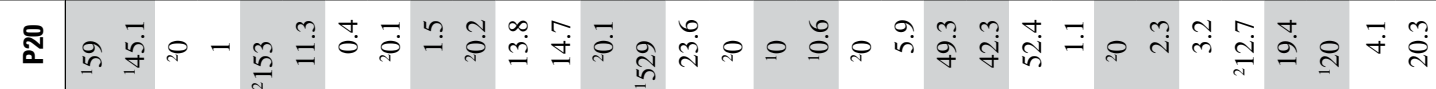

产

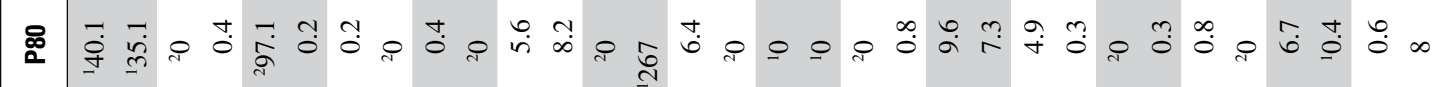

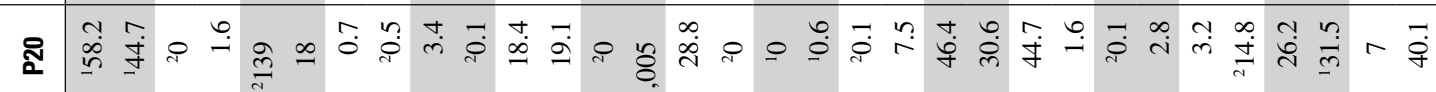

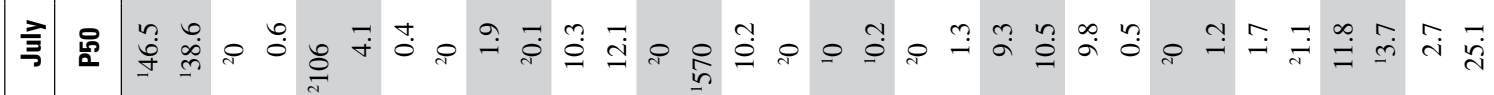

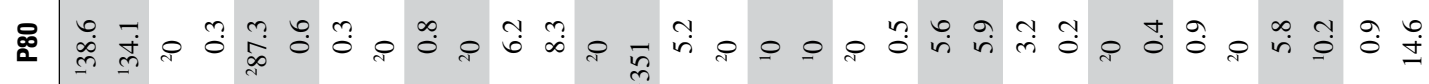

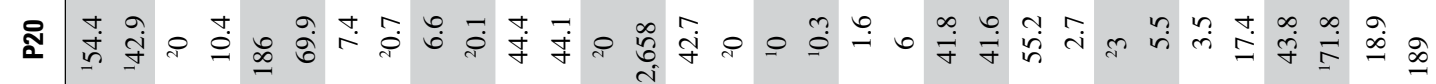

馬

.

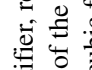

ळ

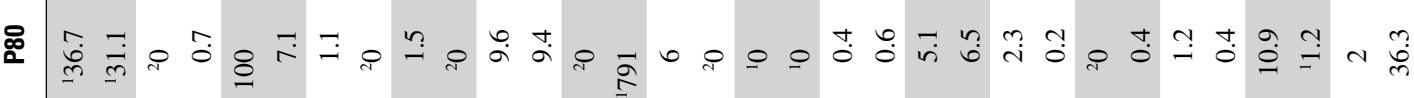

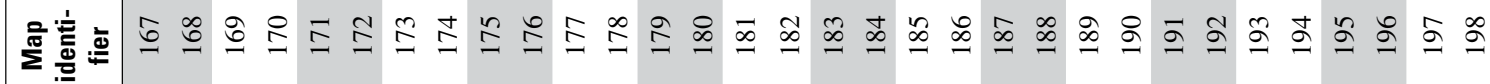




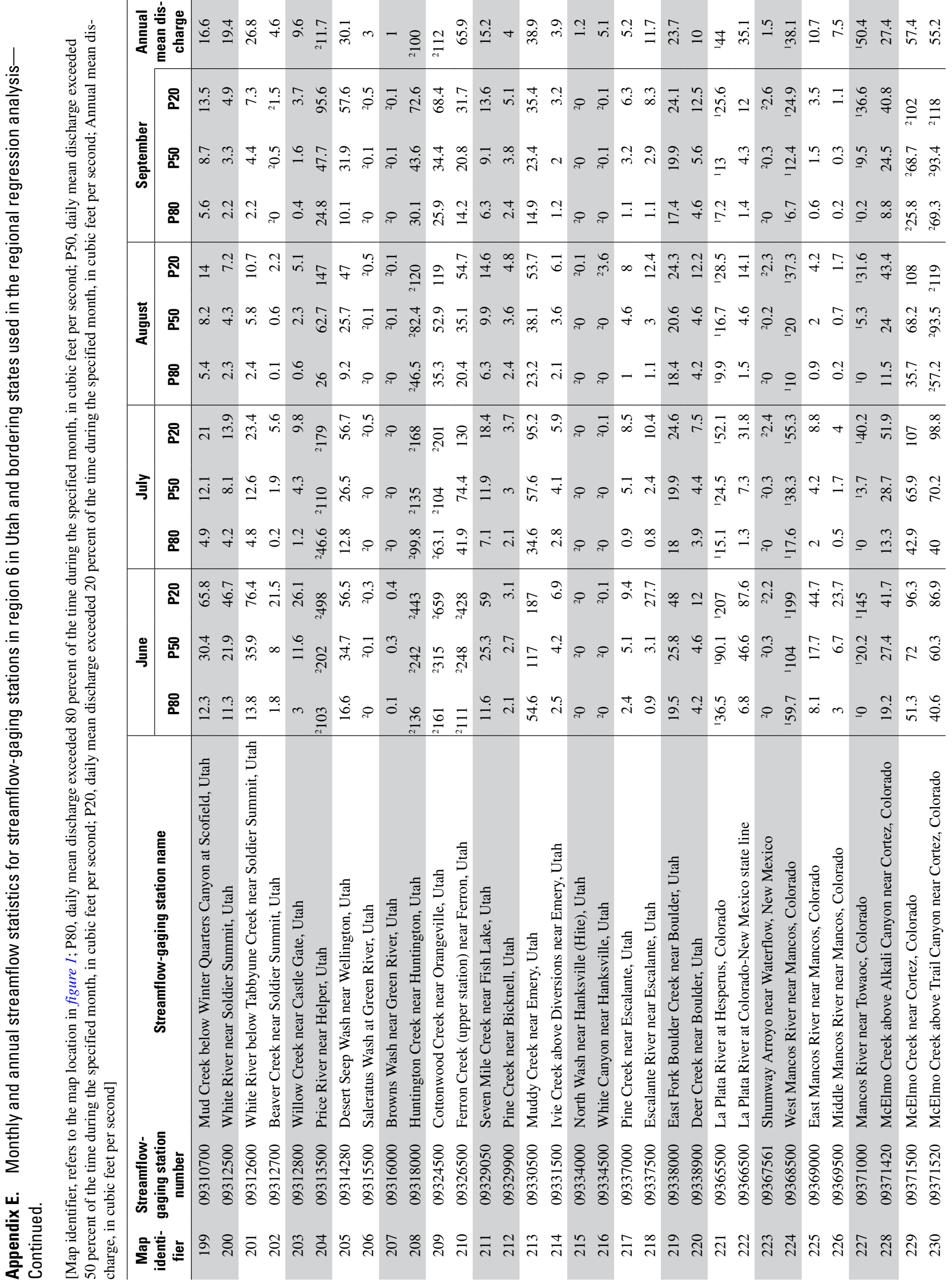




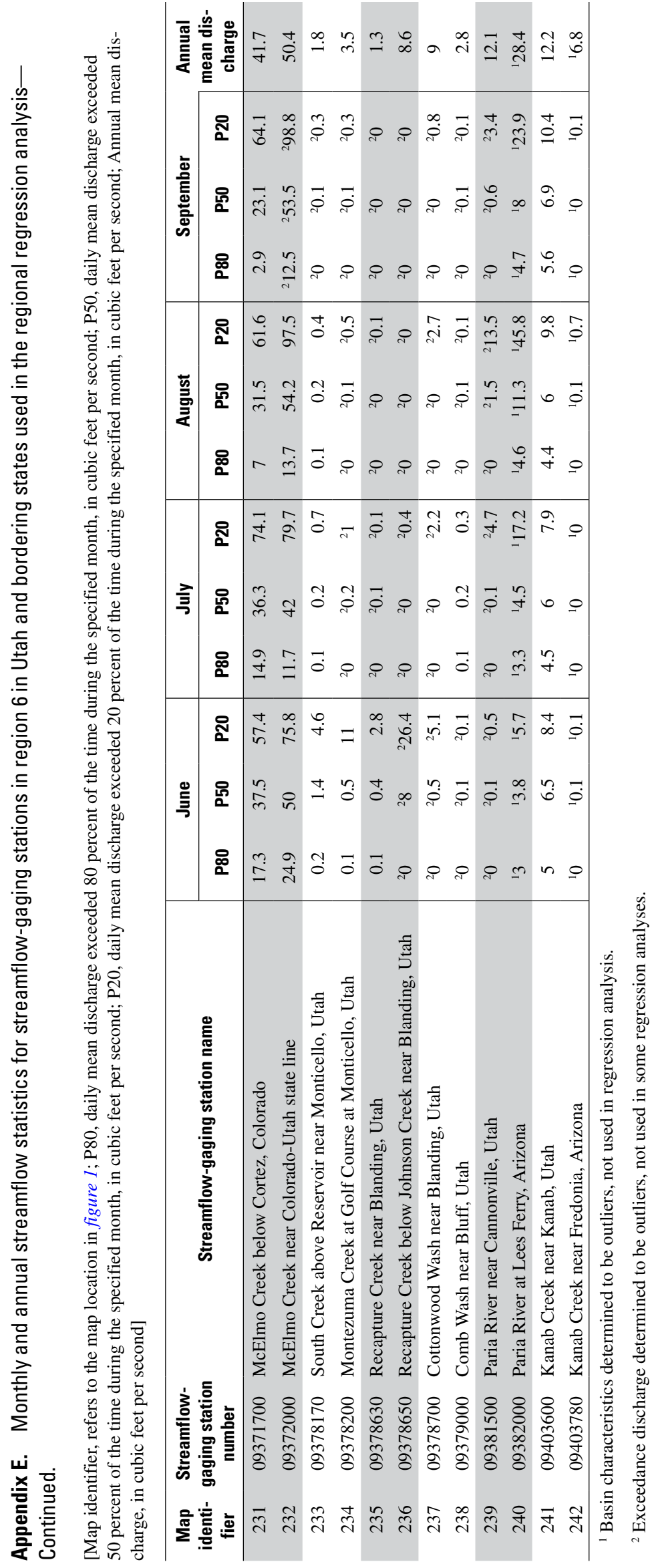


58 Methods for Estimating Monthly and Annual Streamflow Statistics at Ungaged Sites in Utah

\section{Appendix F.}




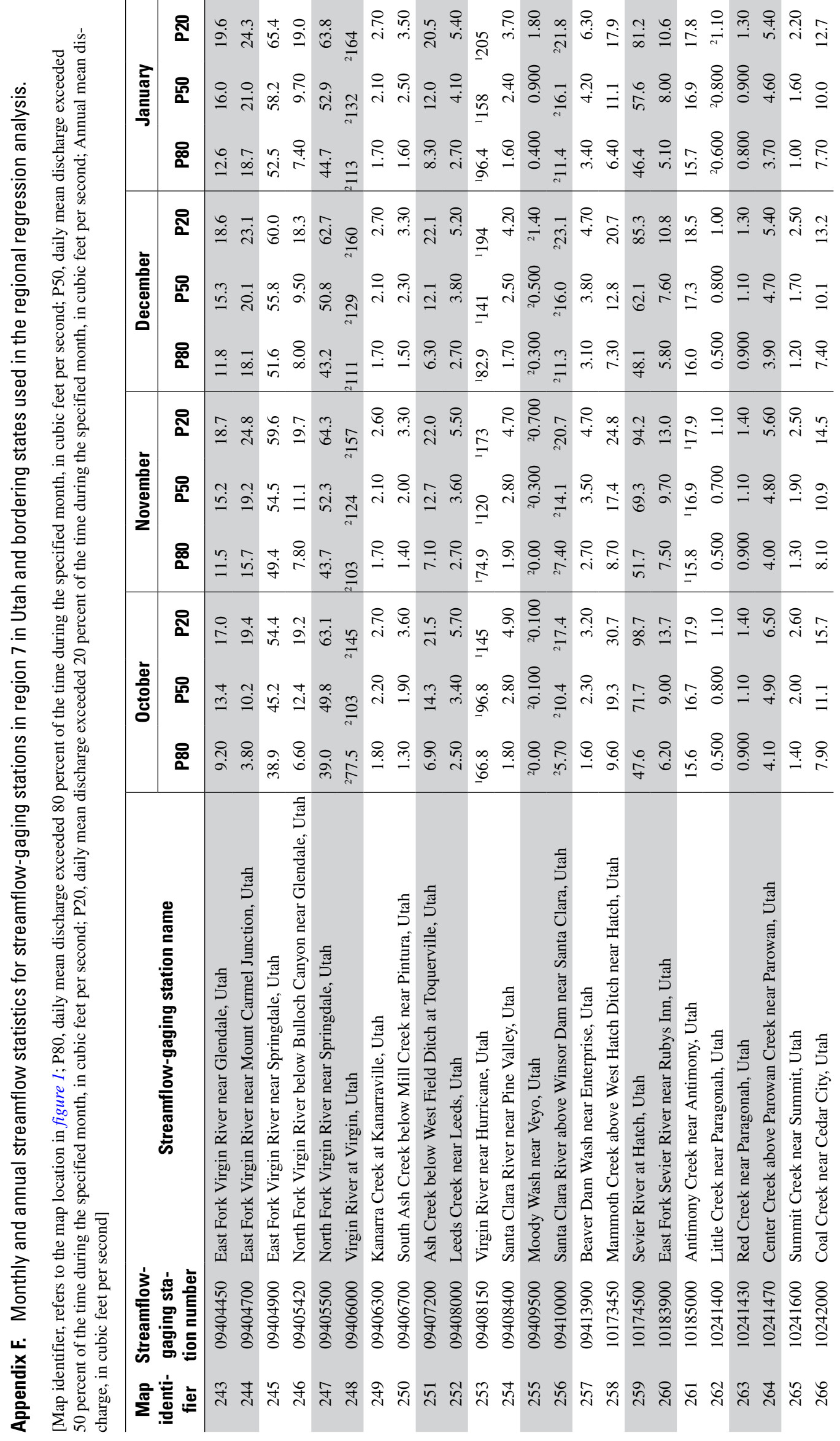




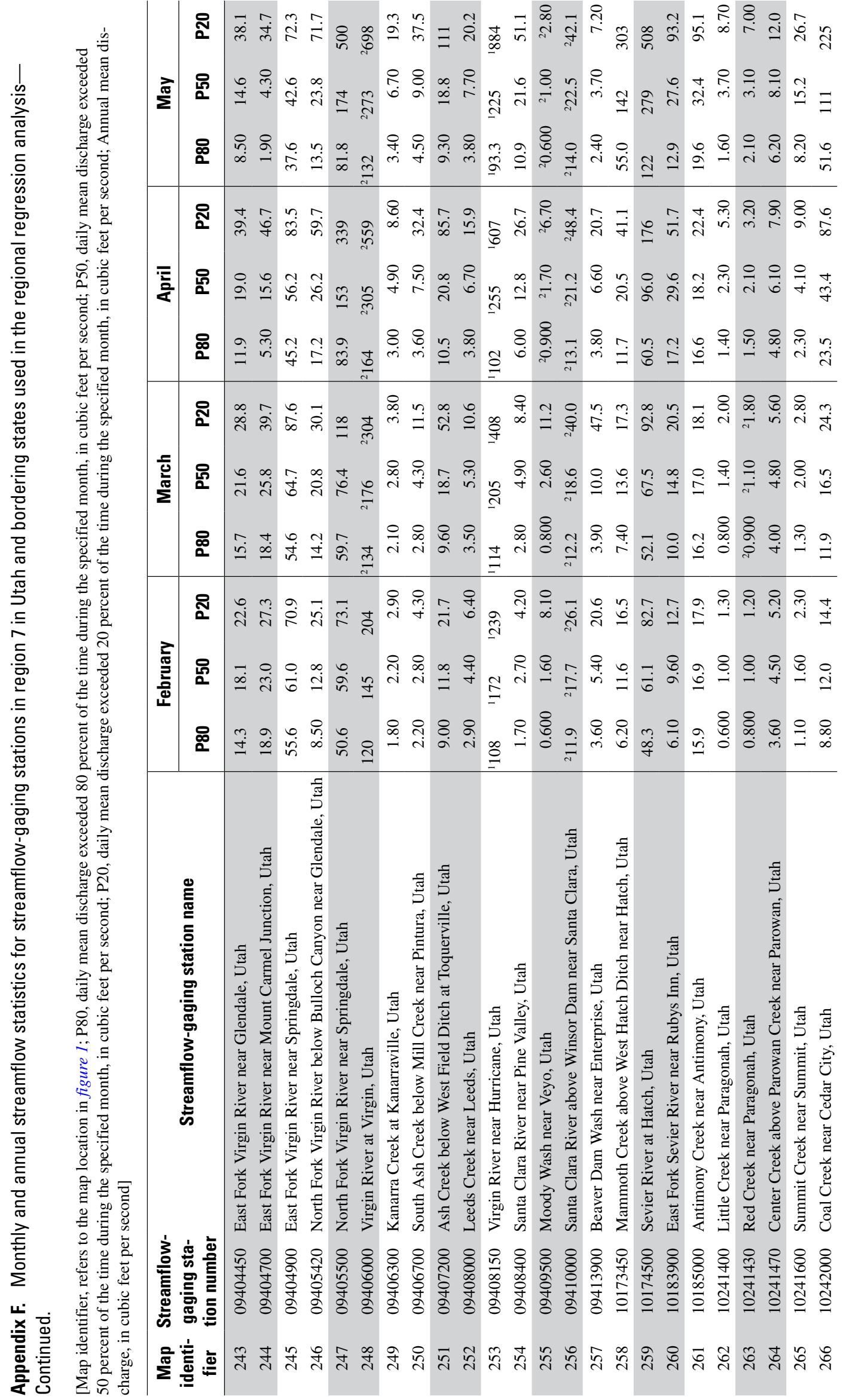




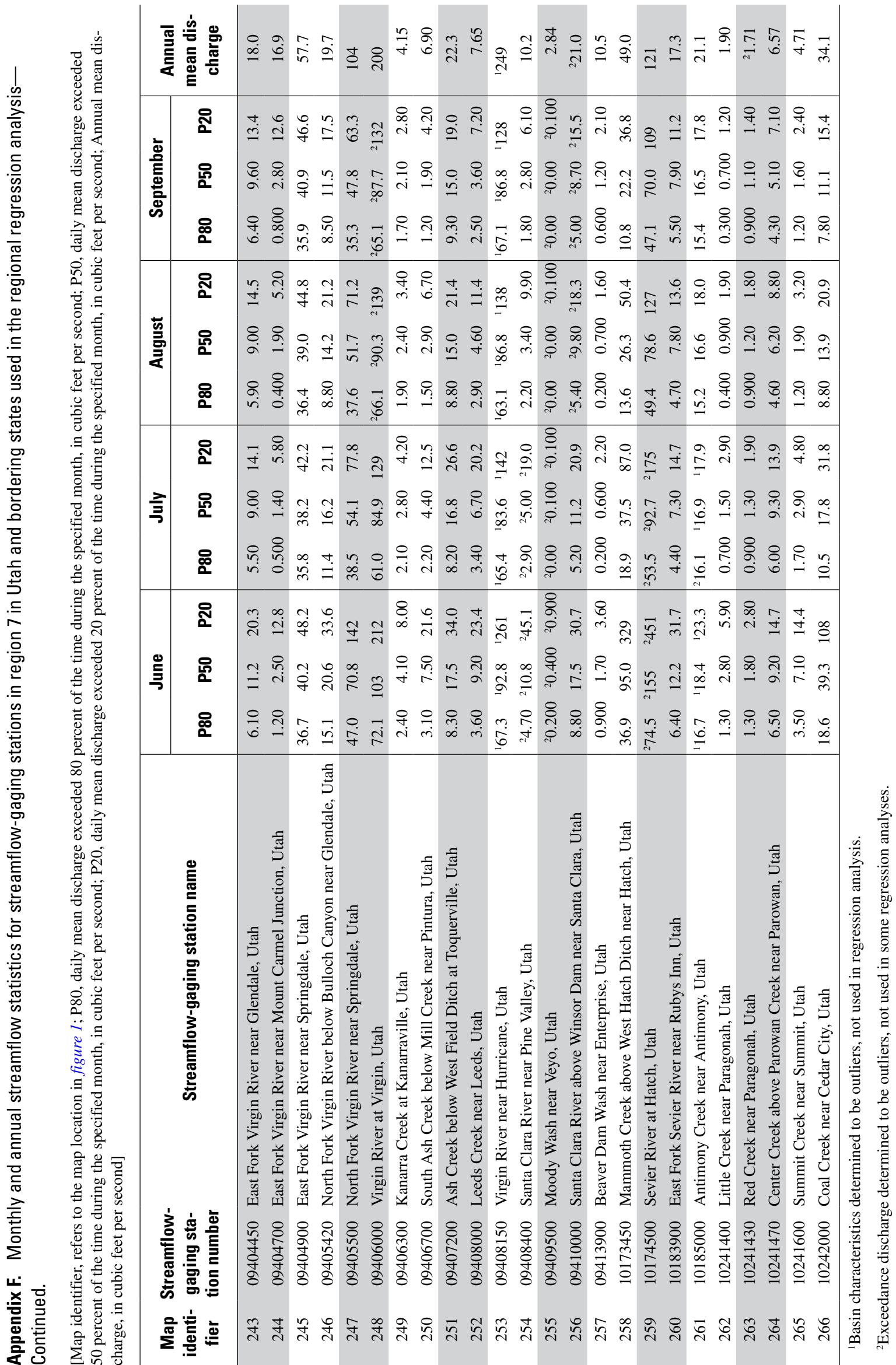


62 Methods for Estimating Monthly and Annual Streamflow Statistics at Ungaged Sites in Utah 


을

总

$\frac{1}{3}$

览

总

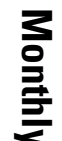

을

울

क

홀.

竞.

ڤ્

悉

高

更

్ㅇㅇ

స్ 